\title{
THE GLOBAL LITERARY CANON AND MINOR AFRICAN LITERATURES
}

\author{
By \\ Amatoritsero Ede \\ A thesis submitted to the Faculty of Graduate Studies and Postdoctoral Affairs \\ in partial fulfilment of the requirements for the degree of

\section{DOCTOR OF PHILOSOPHY} \\ in

\section{English}

Carleton University

Winter, 2013

(C) Amatoritsero Ede 
Library and Archives

Canada

Published Heritage

Branch

395 Wellington Street

Ottawa ON K1A ON4

Canada
Bibliothèque et

Archives Canada

Direction du

Patrimoine de l'édition

395 , rue Wellington

Ottawa ON K1A ON4

Canada
Your file Votre référence

ISBN: 978-0-494-94555-1

Our file Notre référence

ISBN: 978-0-494-94555-1
NOTICE:

The author has granted a nonexclusive license allowing Library and Archives Canada to reproduce, publish, archive, preserve, conserve, communicate to the public by telecommunication or on the Internet, loan, distrbute and sell theses worldwide, for commercial or noncommercial purposes, in microform, paper, electronic and/or any other formats.

The author retains copyright ownership and moral rights in this thesis. Neither the thesis nor substantial extracts from it may be printed or otherwise reproduced without the author's permission.
AVIS:

L'auteur a accordé une licence non exclusive permettant à la Bibliothèque et Archives Canada de reproduire, publier, archiver, sauvegarder, conserver, transmettre au public par télécommunication ou par l'Internet, prêter, distribuer et vendre des thèses partout dans le monde, à des fins commerciales ou autres, sur support microforme, papier, électronique et/ou autres formats.

L'auteur conserve la propriété du droit d'auteur et des droits moraux qui protege cette thèse. $\mathrm{Ni}$ la thèse ni des extraits substantiels de celle-ci ne doivent être imprimés ou autrement reproduits sans son autorisation.
In compliance with the Canadian Privacy Act some supporting forms may have been removed from this thesis.

While these forms may be included in the document page count, their removal does not represent any loss of content from the thesis.
Conformément à la loi canadienne sur la protection de la vie privée, quelques formulaires secondaires ont été enlevés de cette thèse.

Bien que ces formulaires aient inclus dans la pagination, il n'y aura aucun contenu manquant. 


\begin{abstract}
Pascale Casanova (World Republic of Letters 2004), invokes Pierre Bourdieu's concept of a metaphoric literary field (xii) to emphasise the literary world as a 'material' and charged political domain where individual writers compete against each other and collectively embody the cultural dominance or subordination of individual countries within an international "literary space" (13). That modern literary space began its formation in $16^{\text {th }}$ century Europe (11) and has since expanded to form a "world republic of letters."
\end{abstract}

This dissertation examines the global "politics of literature" (Valery Labaurd qtd. in Republic of Letters 10) as it relates to the struggles of a "dominated" (83) African writing. I investigate global canon-formation as a function of African literature's marginalisation within a 'powerful' Eurocentric global literary canon. I maintain that African writing is minor in global canonical terms even if it might appear more visible due to the prominence of African writers like Wole Soyinka, Chinua Achebe, Ngugi Wa Thiong'o or Ben Okri. I explore the minor status of modern African literature by investigating global literary validating mechanisms and canon-forming processes in relation to a newer corpus of Nigerian writing. I conclude that while Africa represents a "dominated literary space" (83) within the global canon, some contemporary African writers find unique ways to subvert the power dynamics at the centre and become consecrated.

My approach is interdisciplinary, encompassing book history and globalisation theory within the tensions of the postcolonial and the postmodern. Lucien Febvre and Marc Bloch's approach to the reading of history and socio-cultural change emphasises "the role of media production technology, the impact of the printing industry, reading 
habits, editorial theory and practice, the socio-economic dynamics of publishing, and the survival of books in relation to change in social structure" (Ibironke African Writers and Heinemann Michigan State U: $\mathrm{PhD}$ Thesis 2008: 3). An analysis of metropolitan reading practices, local and international editorial processes and global market dynamics will provide answers to the question contained in my initial proposition: why is modern African literature in the global margins? 


\section{DEDICATION}

To the memory of my maternal grandmother, Limota Ajibodu; Nicole Ng, Ralph

Hillebrandt and Antje Herren for support and to Alero Okoturo-Ede for her patience in all of this 


\section{ACKNOWLEDGMENTS}

I am forever indebted to my supervisor, Dr. Pius Adesanmi, who inspired me at many doubtful moments in the writing process and provided intellectual nurture in formal and informal capacities. I also owe enormous debts of gratitude to the members of my dissertation committee, Drs. Brian Johnson, Sarah Casteel and Tunji Osinubi, whose diligence and rigour in their feedbacks provided able guidance. Dr. Johnson gave me copious and detailed reports, which made progress swifter even while I appeared to be stuck. Carleton University's MacOrdum library was very helpful in making unusual allowances and giving me special borrowing privileges. I particularly extend my gratitude to Mr. Mulugeta Gebru on the staff of the library. Colleagues and friends like Nduka Otiono, Akin Adesokan, Maik and Angela Nwosu, Kole-Ade Odutola, Andrena Pierre, and Rina Egbo, gave important moral support and encouragement during the writing process. The friendship and support of Lequanne Collins-Bacchus, my long-suffering informal first reader, was invaluable. I express my gratitude to the Social Sciences and Humanities research Council, whose fellowship award contributed, in large measures, to the successful completion of this dissertation. 


\section{TABLE OF CONTENTS}

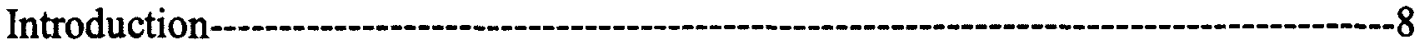

\section{Chapter One}

Of Canons, Anthropology and Generations -

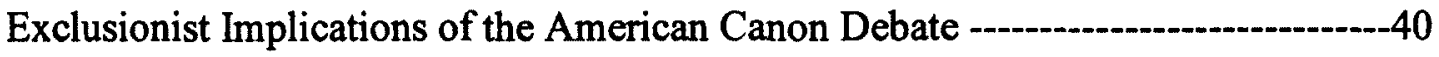

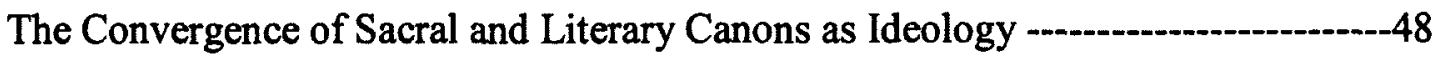

The Limits of Cultural Capital ---ons

The Three Generations of African Writers -.....-67

\section{Chapter Two}

The Global Market in the Local Margin --_

African Literature and Anthropology--

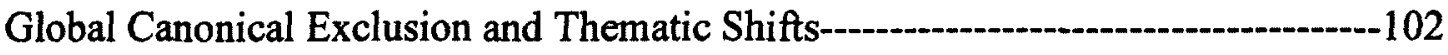

Chapter Three

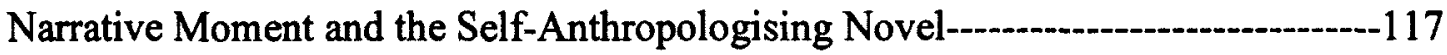

War and Child Soldier--128

Crime and Corruption --.--.--143

Tales of Polygamy and the Modern Domestic Realm -

\section{Chapter Four}

The Nigerian Canon and Cultural Identity -

The NLNG and Local Literary Politics --.-163

The Retrieval Canon ---_-

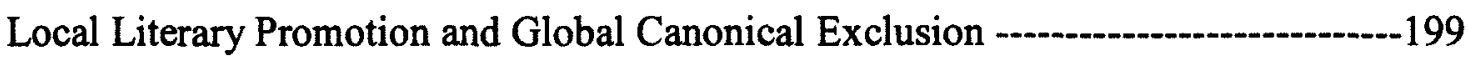

\section{Chapter Five}

Navigating the Retrieval Canon --.--_-

Escaping Local Retrieval --a-10

Hidden Texts and Invisible Chapters--

Conclusion --.--

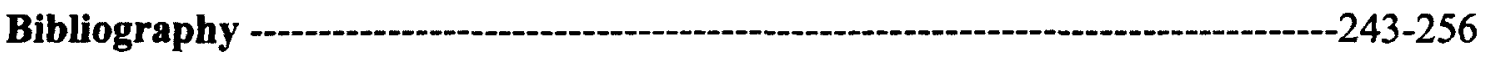


The Global Literary Canon and Minor African Literatures Amatoritsero Ede 


\section{Introduction}

[...] I worry that a careless incorporation of "the Other voice" into a literary tradition can, if it is only appendative, function simply as a mechanism of covert marginalization (Gikandi, Maps of Englishness, 1996: 5).

Pascale Casanova (World Republic of Letters 2004), invoking Pierre Bourdieu's concept of a metaphoric literary field (xii), re-conceptualises the literary world as a 'material' and charged political domain, where individual writers compete against each other, and collectively embody the cultural dominance or subordination of individual countries within an international "literary space" (13). According to her that modern literary space began its formation in $16^{\text {th }}$ century Europe (11) and it has since expanded to form a "world republic of letters," which, I believe, Europe still dominates due to its relatively being the "oldest" (83) tradition in the canon of modern letters in European languages. That dominant tradition has been sustained even as other canons of modern writing develop and orbit that European core', within even which there have also always been literary historical power shifts amongst competing Western epicentres of literary prestige $(10-11 ; 165)$.

I maintain that global literary visibility and pre-eminence is Euro-centred because, although Casanova says that "the configuration of the contemporary literary space is not easy to characterize" (164) [and is] "polycentric," still [the] "transitional phase" (164) she says we are in is one located mostly in Europe. "It may be that we find ourselves [...] passing from a world dominated by Paris to a [...] plural world in which London and

\footnotetext{
${ }^{1}$ Concern here is with the pre-modern and modern periods. It should be noted that there were much older writing cultures in the ancient world before Europe. An example is Ancient Egypt's hieroglyphics writing system, which predated Europe by millennia. See Theophile Obenga's African Philosophy: The Pharaonic Period: 2780-330 (2004:21).
} 
New York, chiefly, but also to a lesser degree Rome, Barcelona, and Frankfurt, among other centres, contend with Paris for hegemony" (164). Important for this work is the fact that Africa, its central geographic concern, is not in contention at all in such matters, and is firmly located in the periphery of the world republic of letters. While a 'centreperiphery' equation is by no means sacrosanct, especially in the face of globalisation, the hierarchies that derived from that altered model of North-South relationship has left enough trace to warrant using - advisedly - that binary to capture the idea of a residual and persistent assymetries of power between the West and the rest (Chinweizu 1975). It is that trace of hierarchies and inequality inherent in globalisation that is of importance here.

Casanova's general argument that there are "dominant [and] dominated" (83, 115ff) or "small literatures" (175) amongst contending national and international writings is important for this study because it foreshadows my positing of African literature as small, marginalised and minor within that configuration. That corpus of writing is eternally struggling to emerge from the periphery into a centre historically located mentally and geographically elsewhere - in the "literary capital[s]" (127ff, 164ff) of the world. The location of the centre permanently elsewhere is a result of historical colonialism with its socio-political, economic and cultural eroding of the periphery.

To emphasise the constructedness of canonical inequity and struggle, I reconceptualise Casanova's 'republic' as a 'global literary canon.' The word 'canon,' with its etymology in a hierarchical privileging of particular biblical scriptures by the 'church fathers' (Bruns "Canon and Power" 1984), underscores the centrality of ideologies of value in the formation of literary taste. Nevertheless, the concept of an 
ongoing, even if imperceptible canonical reconfiguration of the world's literary field is also implicit in the formulation, 'global literary canon.' That inexorable dynamic is an explanation for the relative, though token, international successes of some new African writing. In an increasingly borderless world (Miyoshi "Decline of the Nation State;" Dirlik "Global in the Local" in Global/Local Wilson and Dissanayake 1996: 78-106; 2145) therefore, the aggregate of contending literary works from different national canons, which succeed in travelling from local canons into global literary circulation and thus becoming part of "world literature" (Damrosch What is World Literature? 2003: 283) form that international conjuncture which I describe as a global literary canon. According to Casanova: "[...] the world of letters must be conceived as a composite of the various national literary spaces [...]" (108). The sense of struggle and symbolic violence in the world republic of letters is implicit in my idea of a global literary canon in which "rivalry, struggle and inequality" (4) is a central operating principle.

This dissertation examines the global "politics of literature" (Valery Labaurd qtd. in Republic of Letters 10) as it relates to the struggles of a dominated African writing. In what follows, I investigate global canon-formation as a function of African writing's marginalisation within a 'powerful' Eurocentric global literary canon. I maintain that African writing is minor in global canonical terms even if it might appear larger due to the prominence of African writers like Wole Soyinka, Chinua Achebe, Ngugi Wa Thiong'o, Nurrudin Farah, Leopold Sedar Senghor or Ben Okri, amongst others. I explore the minor status of modern African literature by investigating global literary validating mechanisms and canon-forming processes in relation to a newer corpus of 
Nigerian writing. I conclude that Africa represents a "dominated literary space" (83) within the global canon.

My approach is interdisciplinary, encompassing book history and globalisation theory within the tensions of the postcolonial and the postmodern. Lucien Febvre and Marc Bloch's l'historie du livre or book-historical approach to the reading of history and socio-cultural change emphasises "the role of media production technology, the impact of the printing industry, reading habits, editorial theory and practice, the socio-economic dynamics of publishing, and the survival of books in relation to change in social structure" (Ibironke African Writers and Heinemann Michigan State $\mathrm{U}: \mathrm{PhD}$ Thesis, 2008:3). This radical historiography is particularly apt in calibrating the inequality between the global North and the global South in cultural matters, especially as subtended by the political and the economic. I highlight hierarchies and dependencies by tracing the contours of cultural production, consumption and exchange. My thesis is that African literature is marginalised within the global literary canon and that such marginalisation is a result of past hierarchies and their present conjunctures. A focus on metropolitan reading practices, local and international editorial processes and global market dynamics will provide answers to the question contained in my initial proposition: why is modern African literature in the global margins?

As a case study I concentrate on the transnational dynamics of recent Nigerian literary production and its global dissemination in relation to the socio-economic and political structures of domination established since colonialism. The subject is broadly approached from Pierre Bourdieu's (1993) overarching conception of a field of cultural production in which texts and authors struggle to position themselves advantageously. 
"The literary or artistic field is a field of forces but it is also a field of struggles tending to conserve or transform this field of forces" (30; original emphasis). To emphasise the idea of 'struggle' within the dynamic of canonical change or expansion, I extend Bourdieu's 'field' to encompass canon formation itself as a post-production stage of cultural production in which published works are in Foucauldian discourse formations in their contention with each other (Foucault trans. Gordon Power/Knowledge, 1980). Such a post-production stage is nevertheless understood as the 'real' production, to which all previous stages are preparatory. Literary production is then only meaningful in so far as texts can embed themselves within the discourse formation of the canon and re-arrange the relations of power within it.

The global canon's mechanisms of resistance to the re-alignment of its power relations, especially where contemporary African literature is concerned, are read as an example of the operations of Edward Said's cultural imperialism (1993). At the background of this study is the history of the colonial encounter, its significance for the emergence of African literature, the postcolonial socio-economic conditions affecting African literary production and the metropolitan ideologies of value surrounding its (de)canonisation.

Those ideologies of value invariably favour themes in consonance with the historically constructed anthropological and demonising Western images of Africa, while at the same time privileging the prose form in new, "third generation" (Adesanmi "Africa's New Intellectuals" in Dark Webs of Remembrance ed. Falola, 2005: 269-285) Nigerian writing. Those demonising themes might seem obvious going by the examples of the overwhelming kinds of contemporary Nigerian novels, which have consistently 
trickled into the canon of world literature since 2001. However a qualification ought to be made - that intimations of the anthropological are 'apparent rather than obvious' in these works. This is because there are no definitive, incontestable ways to measure what I will be referring to as 'self-anthropologising' in some - and not all - contemporary Nigerian writing. That tendency is not so much a deliberate rhetorical ploy as a discursive response to a historical constructed contemporary Western Market, on the one hand, and to a lay and exotic metropolitan literary consumption of Africa, on the other. The dynamic of the market, literary taste, and writers' responses are in a flux and are not easily reducible to a set of hard-edged facts.

It must be noted that Biyi Bandele-Thomas' first three novels published in the 1990s, The Sympathetic Undertaker and Other dreams [1991], The Man Who Came in from the Back of the Beyond [1991] and The Street [1999], were, arguably, the first works of fiction by a member of the generation to break into the international academic canon [...]." (Adesanmi and Dunton "Nigeria's Third Generation Writing" in English in Africa 2005:10). Nevertheless, it is Helon Habila's winning of the British Caine prize in 2001 with "Love Poems," a story in the dystopic collection, Prison Stories ${ }^{2}$ (2000) - later published by Penguin as Waiting for an Angel (WFA) (2002) - which initiated a consistent global, even if still token, canonisation of some of Nigeria's new writers through international awards ("Nigeria's Third Generation Writing" 11). Such works were then further inserted into global school curricula. The year 2001 then marks the beginning of an international literary privileging of themes of an exotic Africa beloved of

\footnotetext{
${ }^{2}$ The author told me in a private conversation that he first privately published Prison Stories and entered one of the stories in the book, Love Poems, for the Caine Prize.
} 
Western anthropology and the ascendance of prose over any other genre in new Nigerian writing.

Pius Adesanmi and Chris Dunton have elaborated on the question of a transnational privileging of the prose genre in contemporary Nigerian writing as a response to metropolitan preferences in literary valuation ("Nigeria's Third Generation writing" 1011). But it is useful to give a brief overview here. Nigeria's third generation writing, beginning in the 1980 s, was associated with the poetic genre at the outset. Subject and theme were mostly inspired by the poor existential conditions attending the oil bust of that decade and beyond. The publication of the representational anthology Voices from the Fringe (Garuba 1988) inaugurated the professional arrival of Nigeria's third generation into the local literary scene. "The decade that saw the emergence of the domestic consolidation of the [third] generation, 1985-1995, was almost exclusively dominated by poets who emerged in parallel formations in the two cities that have acquired a reputation in Nigeria's literary history for being sites of generational beginnings: Ibadan and Nsukka" ("Nigeria's Third Generation Writing" 8 ).

During that period the only notable prose works locally produced - even if by transnational Nigerian publishers - are Omowunmi Segun's The Third Dimple (1990), Karen King Aribisala and Sola Osofisan's short story collections Our Wives and Other Stories (1991) and The Living and the Dead (1991) respectively. This is apart from those Bandele-Thomas' works mentioned earlier. Indications of a metropolitan privileging of anthropological and exotic themes and the prose fiction genre respectively were signalled when Aribisala's tales of African polygamy won the Commonwealth prose prize in 1991. Emphasising the predilection for prose is the British literary establishment's earlier 
cancellation of the Commonwealth poetry prize for Africa after 1987 when it was last won by the second generation Nigerian poet, Tanure Ojaide. While Osofisan and Segun's works above are in the globally privileged prose form, their thematic preoccupations did not follow the preferences of global canonising literary establishments. Osofisan's work is rather dark and dystopic, as suggested in its title. It could easily be read in certain contexts as self-anthropologising nevertheless, the fetishizing reception circumscribing global institutional validation of new African writing had not yet properly taken hold by the early 1990s. And although both Osofisan and Segun won the Association of Nigerian Authors' (ANA) local literary prizes for their efforts, this did not result in the kind of literary visibility usually engendered by the award of a metropolitan prize.

The final confirmation of the apparent new metropolitan preferences for African literary production in genre and theme can be deduced from the literary reception accorded exiled third generation writers, both poets and novelists, who migrated to literary capitals of the world beginning in the 1990s in search of publication outlets, amongst other reasons (Voices from the Fringe xv). These émigré writers have continued to produce poetry and fiction respectively at different rates. However, it is the prose writers - and predominantly those investing in the 'exotic' and themes that could be (mis)read as anthropological - who have remained visible in international literary circuits and on metropolitan academic curricula. This is attested to by the already mentioned win of a British Caine prize by Habila in 2001 with his dystopic novel, the Orange prize short-listing of Chimanada Ngozi Adichie's novel on African domestic realm and patriarchy, Purple Hibiscus, in 2004 and her winning of the same in 2007 with Half of a Yellow Sun. That novel perfectly fits the self-anthropologizing preferences of 
metropolitan canonisation with its romanticised Nigerian civil war theme. Thus important milestones in the local and global emergence of this new generation of Nigerian writers is 1985-1995, 2001 and beyond. In consequence of the canonical preferences for novels in the internationalisation process this dissertation is primarily concerned with third generation Nigerian prose fiction.

In his study of the centrality of British Heinemann Educational Publishers' African Writers Series to the emergence of modern African literature, Olabode Ibironke (2008) emphasises the importance of the transnational corporation in the internationalisation of African writing. I depart from him in focusing on how the same transnational cultural production is, ironically, both a condition for, and limitation to, the global dissemination of African writing. Concretely I undertake a case study of Nigerian literature's historically limited transnational production and dissemination to show how power inequities between the centre and the periphery are sustained culturally. Questions of how local and transnational publishing practices and the politics of dissemination combine to marginalise African writing are important for this dissertation. That is usually inflected by ideologies of value and global institutional validation, which limit African literature as, or reduce it to, an "appendative function" within the global canon as the epigraph at the beginning of this introduction suggests of cultural objects from the periphery.

I read primary third generation texts of the literary-anthropological kind to expose anxieties about literary production and dissemination in their subtexts. Some of these are, for example, Beast of No Nation (Iweala 2005), I Do Not Come to You by Chance (Nwuabani 2009), The Secret Lives of Baba Segi's Wives (Shoneyin, 2010) and Half of a Yellow Sun (Adichie 2006). The successes of these fictional works are highlighted by a 
critique of two contemporary novels, which have been relatively unsuccessful in terms of global dissemination and visibility due to their departures from the themes beloved of metropolitan canonisation. Their invisibility is in spite of their being published in literary capitals and being works of prose, the preferred genre for metropolitan canonisation. I refer particularly to Arrows of Rain (Ndibe 2000) and A squatter's Tale (Oguine 2000). Juxtaposed with the two forgoing are those novels - such as Akin Adesokan's Roots in the Sky (2004), Maik Nwosu's Invisible Chapters (2001) and Sanya Osha's Naked Light and Blind Eye (2010) - that are relegated to a relatively worse global obscurity and are limited mostly to local or very limited metropolitan circulation. A common characteristic of these obscure efforts is that they mostly do not conform properly to the anthropologising demands of global canonisation. Where their themes are dystopic, they might not be sensational or exotic enough for anthropological Western consumption. It is noteworthy that they invariably also have technical, infelicities of editorial production or are usually not published in a literary capital such as London or New York, except for Osha's work.

In other words literary visibility or obscurity can be the result of several complex factors of which ideologies of value are only one. Apart from the force of ideological validating institutions, such factors might include market conditions, place of publication, literary and editorial quality, scholarly or critical reception, critical or popular reviews and lack of them, time of publication, size of print run and so on. It is important, however, to note that the effects of these factors are interdependent and that their sum is easily influenced by the centre's ideological preferences. 
As I have suggested so far, in order to position themselves advantageously within the field of global cultural production new Nigerian fiction writers are forced to resort to a self-anthropologising mode of narration. This is to satisfy traces of that peculiar historical and stereotypical Western public taste for reading African literature as if it were anthropology or ethnography. That kind of reading practice or literary criticism, according to Ato Quayson's critique (Strategic Transformations 1997) of Obeichina's Onitsha Market Literature (1972), makes the text "amenable to a positivist anthropological harvest in which details are read directly from cultural background to fictional world and back again" (2). He questions Christopher L. Miller's single-minded and elaborate reduction of African literature to anthropology in Theories of Africans (1990). Graham Huggan (Postcolonial Exotic 2001: 37ff) also queries Miller's justification of anthropology (or ethnography) as a valid, indeed, 'necessary,' tool for reading African culture in spite of the guilt of anthropology in the colonial project. His critique is in the foreground of Chidi Amuta's (Theory of African Literature 1989) gruff bole-kaja ${ }^{3}$ impatience with Miller, the 'American' or African critics ${ }^{4}$ who form a "cultural anthropology school" (Postcolonial Exotic 38) and introduce the same anthropological registers or metaphors in criticism. Those new writers who deploy selfanthropologising tropes within creative writing could be added to Amuta's list.

\footnotetext{
${ }^{3}$ Literally meaning 'come-down-and-lets fight' in the Western Nigerian Yoruba language. This is a phrase denoting an aggressive, no-holds-barred type of criticism in popular literary reviews on the pages of Nigerian newspapers. In the 1980s Chinweizu made this mode of criticism popular in his unsparing critiques of Wole Soyinka's "shamanist obscurantism" between the literary pages of the Nigerian Guardian newspapers. It later became the overriding tone of Chinweizu, Onwuchika Jemie and I Madubuike's Towards the Decolonization of African Literature (1989).

${ }^{4}$ Chidi Amuta, according to Huggan, chastises even such prominent African critics as Wole Soyinka and Biodun Jeyifo. Amuta accuses their criticism of being a "'ethnocriticism' [that] subscribes to a hypostatized 'traditionalist aesthetics,' usually driven by romantic-idealist notions of 'traditional' African cultures and often allied to an equally spurious 'pan-Africanist universalism"' (Amuta 1989:41 in Huggan 2001: 38).
} 
The materialist and book-historical methodology of this study gives priority to socio-economic and political contexts as well as to texts. This follows Benita Parry's materialist critique of 'postcolonialism,' which questions an over-valorisation of texts above socio-political and economic contexts of cultural production leading to "an essentially textualist account of culture"' (Sparks 1996: 97-99 in Parry 2004: 4). Parry also notes that this critical tendency is responsible for literary theories of the 'postcolonial,' which understand that term literally and performs a scission between colonialism and the politics of contemporary postcolonial cultures and societies. The intention here is to frame contemporary African literature, and specifically Nigerian writing, within the postcolonial continuities of its colonial emergence and transnationalisation and its consequent historical subordination as a 'tributary' of the global literary canon. In that regard, an initial theoretical overview of the workings of canons, anthropology and generational divides in Nigeriana will be followed by the engaging of representative texts in close readings. It should be noted, however, that a cultural materialist approach here should not be conflated with the anthropological or sociological mode of reading African literature that this work generally critiques. Cultural materialism is germane only in the sense of an engagement of the 'material conditions' surrounding cultural production.

The appropriateness of the term 'postcolonial' has been much debated and contested by many critics for its ontologically loaded deployment in postcolonial theory while it, at the same time, suggests a surpassing of the existential burdens it evokes. The term 'postcolonial' in this dissertation serves a dual role wherever it appears. Firstly, it should be understood to retain a hint of an existential continuity with colonialism and its 
burdens, and secondly, it denotes the simple adjective, suggesting a temporal surpassing of physical colonialism - after colonialism. These discrepancies are important in emphasising the continuity between colonialism and contemporary culture while avoiding that incessant historical scission, which is implicit in persistent unqualified discursive invocations of the term, 'postcolonial.'

Due to the relatively large emigration of a new crop of Nigerian writers in the 1990s because of various reasons ranging from a search for publishing outlets to the socio-political, educational or existential, the question of writers' location has become important to contemporary local literary politics. Nigeria's modalities for local canonisation were, until recently, circumscribed by a politics of location, which excluded the migrant Nigerian writer, of which I am, myself, one. I moderate discussions on an exclusive virtual sphere - krazitivity $^{5}$ - made up of fellow local and migrant third generation writers. From that vantage point, I argue that one of the unspoken reasons for the past marginalisation of that group is the over-simplified belief by the local literary establishment that migrant Nigerian writers have rich global opportunities for the publication and dissemination of their work ${ }^{6}$. My investigation seeks to show that such assumptions might not be completely accurate. I extend previous discussions about the canon - for example the American 'canon wars' - by considering contemporary Nigerian literary production and the resulting transnational canon as an example of the limitation

\footnotetext{
${ }^{5}$ Krazitivity is a literary discussion group made up of third generation Nigerian writers in Nigeria and the Diaspora See <http://groups.yahoo.com/group/krazitivity/>. Accessed 13 February 2013.

${ }^{6}$ One or two migrant Nigerian writers, notably Chika Unigwe, were of this opinion. She felt that "exile" did not hinder a writer's possibilities. Perhaps she unconsciously projected her own successes unto others. The occasion was an African Literature Association (ALA) women writers' roundtable in Macomb, USA in 2009. Apart from Unigwe, Sefi Attah and Unoma Azuah were participants. The subject was on the relationship between the condition of exile and a writer's craft. I was present at this event. See also Chux Ohai's "Endless Controversy" (Nigerian Independent Today, May 31, 2004).
} 
of African writing within the global literary canon, irrespective of a particular writer's location.

I concentrate on Nigerian writing because it is a corpus whose socio-cultural and political backgrounds I am very familiar with - especially as a member of that 'third generation' of writers that is my focus. Moreover, Nigeria is the largest country in Africa demographically, with a conservative population of over 140 million according to the 2006 United Nations Social Development (UNSD) statistics ${ }^{7}$. For sheer size, Nigerian writers and writings account for, arguably, the largest on the continent and in the Diaspora. Amongst other factors - and even at the very inception of African literature in the $20^{\text {th }}$ century - that numerical strength has resulted in a correspondingly overwhelming literary production in comparison to other countries on the continent and their relatively smaller populations. According to Charles Larson in a 1980 retrospective literaryhistorical essay, "New Writer; New Readers" "[l]ooking back at the past 25 or 30 years, it is clear that the writing of fiction in sub-Sahara Africa has been dominated by Nigerians" (1).

Nigeria's enormous population, its large pool of writers and its market potentials even as far back as the 1960s as literacy and readership increased (81) - also explains why "the African Writers' Series," (Hill 1971: 20) an important canon-making institution in African letters, "was initially founded on Nigerian fiction" (20). The overwhelming volume of Nigerian literary output, both visible and hidden, makes it a microcosm of the vigour of modern literary production on the continent. Needless to say that the vigour of Nigerian writing across generational divides has also been attested to by, ironically, the

\footnotetext{
${ }^{7}$ See the UN Website at <http://unstats.un.org/unsd/demographic/products/vitstats/default.htm>. Accessed 13 February 2013. This should lead to the following demographic tables http://unstats.un.org/unsd/demographic/products/vitstats/serATab2.pdf $>$. Accessed 13 February 2013.
} 
several global literary prizes it has drawn to the continent - from the Nobel to the Booker and the Caine - even if these are tokenist in canonical matters as I shall be arguing. Contemporary Nigerian literature still represents and is symbolic of the modalities for African cultural insertion into the project of Euro-modernity.

At the outset certain definitional questions central to this study need to be examined closely. For a writing tradition that is relatively young, African literature as a concept has to perform more than the traditional understanding of literature as simply 'the literary.' There is a need to capture its recent 'physical' growth and transition from speech to writing - especially in consonance with the cultural materialist scope of this work, and to emphasise the materiality of the text.

Generically speaking, the term 'literature' in this dissertation does not merely depict creative writing or the literary but follows Terry Eagleton's description of its very broad conception in England before the Romantic period (Literary Theory 1983:17-18) ${ }^{8}$ and similarly embraces an African library ${ }^{9}$ (Mudimbe The Invention of Africa 1988). It includes the simple letter, political pamphlets and treatises, journalese, folk tales, essays, translations; writing in African languages as well as the memoir, autobiographical fiction, philosophy, the novel, drama and poetry. The emphasis - in highlighting the transition from orality to writing - is on the physicality of the verbal inscription as a natural progression from speech to writing as noted by Derrida (Of Grammatology 1967) or as described in its functionality by Ignace Gelb (A Study of Writing 1952) before him. However, the primary literature examined here can only consist of those kinds of modern African writing that usually circulate within a literary canon, global or local, as a body of

\footnotetext{
${ }^{8}$ See all of chapter one.

9 This phrase is inspired by V. Y Mudimbe's description of the archive of colonialist literature as a "colonial Library."
} 
imaginative work - that is, literary or creative writing in a European language - English in this instance. This is in consonance with my chief preoccupation with a 'global literary canon' as such, which only admits works in Europhone languages or translations into European languages.

'Global literary canon' refers to a configuration anticipated by Goethe in his 1827 declaration that the moment of a 'Weltliteratur' or 'world literature' transcending national literatures, had arrived (What is world Literature? 2003: 1ff). Even if Goethe's "world"10 only referred to the countries of Europe in 1827 , or if the term itself is problematic in its original conception or can be ambivalent in its meaning as discussed in "The Direction of Goethe's Weltliteratur" (Hoesel-Uhlig in Prendergast Debating World Literature 2004: 26ff), the idea of a 'world literature', understood literally, has evolved due to historical configurations. For example, a World System, propelled by capital accumulation and going as far back as 5000 years (Wallerstein World System 1975; The World System Frank and Gills, 1993) has resulted today in a global socio-economic, political and cultural conjuncture (Appadurai Modernity at Large 1996) that is global modernity (Dirlik 2007).

The 'global literary canon' is a formation similar to, but not articulated - as noted by Prendergast in his introduction to Debating World literature (2004) - within Arjun Appadurai's "five dimensions of global cultural flows" (Modernity at Large 33). One of those dimensions is "mediascape" (35), which involves the global circulation of images. Prendergast has noted Appadurai's omission of the circulation of 'print' in the former's analysis. Here the global literary canon is an aggregation and global circulation of

\footnotetext{
${ }^{10}$ According to Jahnheinz Jahn (1968) "[t]he European educated public around 1900 saw 'world literature' as confined to Europe, save for a few works from the near and far East [...] The rest of the world contained 'folk poetry' - a literary desert , in fact, with extremely modest blooms" (16).
} 
'privileged' texts; a collection of trans-cultural/transnational libraries "intimately bound up with world-historical processes" (Debating World Literature viii) and forming a metropolitan archive within a global publishing network - metropolitan because the global canon is historically and mentally located at the centre. This gives a different nuance to the expression 'world literature' - which used to be, at various literary historical junctures - a pseudonym for 'comparative literature' or 'commonwealth literature', and was a politically correct, euphemistic description of Area Studies quota (Zeleza's The Study of Africa Vol. 1 2007: 1ff) within metropolitan academic syllabi. When unyoked from its originary ambivalent meaning, world literature, properly constituted, is the global 'travelling' text. That flow of aesthetic form is diffuse, floats free of, and is "disembedded"11 (see Giddens 1999 in Kiely 2005:26) from national markets, audiences and sites of production, while at the same time pointing back to them ${ }^{12}$.

My conception of global literary canon is to be understood in the sense of a globalisation of culture through the spread of aesthetic form around the globe as inaugurated by history (Moses 1995). It expresses the idea of literary cosmopolitanism inherent in the descriptive, 'world literature,' but jettisons the latter's prejudicial tendency towards a negative euphemism - 'ethnic' literature. It retains the sense of competition in a world republic of letters, with an emphasis on the ideological nature, as

\footnotetext{
${ }^{11}$ This is a term deployed by Anthony Giddens to explain the displacement of local phenomenon unto the global.

I2 Jahnhenz Jahn's (1968: 16) distinguishes 'world literature' from national literature based on whether it is multilingual or monolingual respectively. That literature which makes linguistic crossovers through translation from one language into another, is trans-nationalized, and becomes world literature. His examples, however, are drawn from and amongst European literature. He added the caveat that any African literature, which hopes to become world literature, has to be written in one of the European languages and be consecrated by the European critical establishment.
} 
encapsulated in the word, 'canon, ${ }^{13}$ of the formation processes of that world republic of letters. This renders some national literatures major and others minor - what Casanova refers to as small literatures - as observed earlier.

Even though the concept of a minor literature is borrowed from them, there is a departure from Gilles Deleuze, Felix Guattari and Marie Maclean's formalist deployment of 'minor' in "Towards a Minor Literature" (1985). While 'minor' is understood in its denotative sense of 'fringe' or 'marginal,' it takes on a connotative depth when filtered through Abdul JanMohammed and David Loyd's concept of minority discourse (1990). Irrespective of the relative successes of some African writers on the global level, it can be argued that African writing is still a 'minor' literature in the sense that it is outside a Western 'great tradition' (F.R. Leavies 1948) and on the fringes of a larger discursive field of cultural production and dissemination, which the global literary canon represents.

JanMohammed and Lloyd define minority discourse as being the phenomenon at work when "texts [are] repressed or marginalized by a [Western] society that espouses universalistic, univocal, and monologic humanism" (Minority Discourse 1). This Western monologism is exactly the 'challenge of the modern,' which other modernities strive or should strive to go beyond as a 'trans-modernity'; or should try to 'de-link' from (Dussel “"Trans'-Modernity" 2002: 221-224; Mignolo "De-linking," 2007). That repression results in a "fragmentation and marginalization of non-hegemonic cultures and communities in academic as well as in other spheres" (Minority Discourse 1). Those spheres, as they are pertinent here, are the globalised Anglophone as distinct from Francophone or Lusophone educational and cultural institutions invested, unwittingly or

\footnotetext{
${ }^{13}$ The word canon has its origins in ecumenical empowerment of certain biblical scriptures. A special issue of the Journal, Critical Enquiry 10 (September 1983) makes it clear in its submissions that ideology is at work where 'the canon' is the topic of discussion.
} 
otherwise, in the marginalisation of Anglophone African writing - Nigerian Literature in this instance.

'Nigerian literature' will have to be a very loose descriptive term. The unstable artificial postcolonial contraption called Nigeria can hardly be described as a nation. It is a state defined by geographical borders and political sovereignty only. In indigenouslinguistic-cultural and political terms it is respectively too diverse and disaffected to be considered as one country ${ }^{14}$. Such disaffection is at the root of threats of secession by the Igbo nation in the 1960s and a major catalyst of the Nigerian Civil war of 1967-1970, the effects of which has left deep fault lines in the country's psyche. The impossibility and problematic of Nigeria as a socio-political entity (Griswold Bearing Witness 2000: 6ff) has been severally discussed, narrativised and critiqued. ${ }^{15}$ As a matter of fact, this sociopolitical conundrum forms the thematic obsession of some second generation Nigerian literary production (Laurence Nigerian Dramatists and Novelists 2001: 223ff).

It is only in terms of the colonial language of address, English, that one can speak of a 'Nigerian literature' especially as regards global canonicity (Sullivan "National Literature" 2001: $74 \mathrm{ff}$ ). For my purposes Nigerian literature is then writing in English and does not encompass writing in the three major indigenous languages of Yoruba, Igbo and Hausa. Nor does it include literature in the other more than two hundred languages or even in Pidgin English, which has a slightly larger speech community than the other minor language groups individually. Problematic as this view is, it is the only unifying

\footnotetext{
${ }^{14}$ See Soyinka's The Open Sore of a Continent (1996) where he argues that the political culture of Nigeria as reflected in dubious elections in dissonance with the will of the people suggests that Nigeria is not a yet a nation.

${ }^{15}$ See Chinua Achebe's The Trouble with Nigeria (1983), chapter one of Eghosa Osaghie's Crippled Giant (1998 16-24); C.C. Agbodike's "Federal Character Principle and National Integration" in Political Restructuring Kunle Amuwo et al eds. (1998: $177 \mathrm{ff}$ )
} 
rubric here for a Nigerian literature, which, in short, is the literature of the Westerneducated transnationanl elite. This raises the spectre of the eternal language debate in African literature (Wali "The Dead End" of African Literature 1963, Ngugi "Europhonism" 2000, Chinweizu Decolonization of African Literature 1983; Adesanmi "Europhonism, Universities and other Stories" 2000). The inaugural argument by Wali in a paper delivered at a conference of Writers at the University of Makarere in 1962 is that writing in non-African languages cannot be considered African literature. The "deadend" of that argument is that 'visible' modern African literature is written in and defined by their Europhone (rather than African) linguistic vehicles - English, French or Portuguese. This is a powerful historical problematic in any discussion of 'African modernity' as it relates to cultural globalisation, and a global literary canon.

Most studies about the history and politics of African literary production as a material process and institutional practice in Africa have usually not investigated the subject in relation to its dynamics within global canon formation. This study aims to fill that gap. For example, Livinus Nwaduito Odozor's "Contemporary Nigerian Literature and the Idea of a Canon" (U of Toronto PhD Thesis, 2004) examines canon formation but mostly in a Nigerian context only. While a local Nigerian canon is of interest in this study, it is discussed in relation to the global canon, within which it is a graduated category. Even if there is a significant body of scholarship on Nigeriana such as that by Adewale Maja-Pearce (1992), Chris Dunton (1992), Wendy Griswold (2000), Margaret Lawrence (1968), Ato Quayson (1997), Bruce King (1972), Holger G. Ehling and ClausPeter Holste-von Mutius (2001), Dubem Okafor (2001) or Charles R. Larson (2001), apart from other foundational scholarly material, they concentrate on the first and second 
generation of Nigerian writing. Focus here is on the new and the contemporary, that is, third generation Nigerian writing.

Chapter one is a theoretical discussion of canon formation as a global imaginary to which the African canon is subordinated. It explores the debilitating material conditions around the production of African writing as a consequence of a colonial historical subordination of African culture to the metropolitan. Having established African writing as being dominated within the global canon, this relationship is then reemphasised within contemporary global canonical limitation of minor literatures as exemplified in the ideological strictures of the American canon wars. This leads to an analysis of the politics of canon formation as filtered through the ideological and discursive imperatives within biblical, pedagogical and literary canons.

There is a discussion of the importance of the writer's access to 'print capital' rather than just 'cultural capital' - as traditionally understood by scholars of the canon towards any form of canonical consideration in the first place. This is exemplified in the literary career of an illiterate Amos Tutuola who, despite not having possessed 'cultural capital,' had metropolitan access to print capital and was celebrated. The irony of that celebration is explored in the anthropological metropolitan publishing requirements and stereotypical views about Africa that enabled that access. The chapter then considers how that initial anthropological Western consumption of African writing now determines the global canonisation of contemporary African literature. Lastly, it periodises Nigerian writing, with a focus on the contemporary group of writers whose praxes are now heavily influenced by the previously discussed ideological nature of global canon formation and its anthropological requirements where African writing is concerned. 
Chapter two examines the contemporary African book market as structured by colonial print capitalism and textual imperialism. It establishes the centrality of the global book market to literary value, and elaborates on contemporary African writers' ideological, thematic and narrative self-positioning to that market in order to insert themselves into metropolitan publishing structures and have access to print capital.

Chapter three provides particular examples of how contemporary African texts navigate the global canon's limitations in their narrative strategies through a close reading of select self-anthropologising third generation novels. Chapter four discusses the instability of the category of nation in local canon formation and the politics of new Nigerian writers' domestic or migrant location as it relates to local consecration. There is a consideration of the impact of an over-accommodating transnational critical industry combined with the phenomenon of the local vanity press on the production of a local 'retrieval canon' which lowers literary standards. It provides evidence for how this further complicates the strictures of global canonisation.

The effect of a lowering of literary standards in the periphery and its further global canonical exclusion of third generation writings at the centre is elaborated upon in chapter five. There is a close reading of select texts, which have become hidden due to a complex of factors, which impede their velocity as travelling texts and excludes them from the global canon-forming processes of the centre. 


\section{Chapter One}

\section{Of Canons, Anthropology and Generations}

The globalisation of African writing through the activities of multinational publishing concerns like Heinemann International (lbironke African Writers and Heinemann Michigan State U: PhD Thesis, 2008; Buxo Development of African Literature Harvard $\mathrm{U}: \mathrm{PhD}$ Thesis, 1998) has brought Nigerian literature into that international circulation of literary texts that can be said to constitute a 'global literary canon.' John Guillory (Cultural Capital, 1993) conceptualises a canon as a secular, curricular and hierarchical list of privileged literary texts. He couches the 'consecration' involved in such a listing in terms of that scriptural "closure" (6) reminiscent of biblical canonical antecedents. A transnational flow (Appadurai Modernity at Large, 1993:27) ${ }^{16}$ of such texts, with its closures or possible openings, gives an idea of a 'global canon.' But it must be noted from the outset that the preoccupation here is not with the literary canon as a pedagogic reading list in the (American) classroom as obtains in Guillory's account (29ff). Concern is with the canon as a global imaginary, of which the transnational classroom is one site of its manifestation - in the form of syllabi or reading lists. For my purposes global canon formation is a symptom of the power dynamics within an overarching historical cultural imperialism and domination.

Europhone Nigerian literature, a fairly recent late twentieth-century phenomenon, has become a small and dominated fraction of the global canon. That

\footnotetext{
${ }^{16}$ Arjun Appadurai discusses strands within an intermeshed global conjuncture in terms of cultural 'scapes.'
} 
domination can be attributed largely to historical socio-economic and political colonial dependencies and their reinforcing cultural inequalities, which are sustained in the present. On a general note Pierre Bourdieu maintains in his sociological critique, The Field of Cultural Production (1993), that all cultural practice is mediated by a system of domination. He emphasises the dynamic between domination and subordination within cultural practice by theorising the artistic world as a "field of forces" $(30,40 \mathrm{ff})$ in which actors - writers or artists - struggle for dominance. This creates "unequal power relations" (30) within the field. Framed against Bourdieu's formulations Pascal Casanova, in The World Republic of Letters (2004), also understands those artistic struggles as resulting in an uneven development of the world's "literary spaces" (83) and in an "unequal structure [...] of literary space" (83).

The political and economic roots of the inequality within the field of cultural production or its synonymous 'world republic of letters' can be inferred from the analogies in Bourdieu and Casanova's analyses. Bourdieu regards the field as an "economic world reversed," (29ff) in the sense that it is highly characterised by the apportioning of symbolic 'value' to artistic goods, and to "positions and positionstakings" (30) by agents within the field. It is a field where "the space of positions [...] is nothing other than the structure of the distribution of the capital of specific properties which govern success in the field [...]" (Ibid.). Casanova, on the other hand, draws on Paul Valery, Wolfgang Goethe and Antoine Berman to highlight the coincidence of economic and cultural processes (within the world republic of letters) in the sense that they both involve an apportioning of, and a 'trading' in, value (op.cit. 12-15). Both critics 
also highlight the fact that the literary field is highly politicised and characterised by a symbolic violence.

The distribution of all forms of capital or the apportioning of value within cultural production between the global South and the global North is invariably mediated by colonialism - as an enduring, violent, political, economic and cultural historical event. Filtered through the lenses of postcolonial discourse, it is the enduring, socio-political economic, psychic and, particularly, cultural legacies of colonialism that is of immediate relevance here in the sense understood when Ato Quayson says that "postcolonialism $[\ldots]$ involves a studied engagement with the experience of colonialism and its past and present effects" (Postcolonializing 2000:2).

In spite of the critical deployment of the hyphenated term 'post-colonial' to sometimes suggest a temporal surpassing of historical colonialism (Ibid. 1), its subsequent neo-colonial forms (Morafia et al Coloniality at Large 2008; Thomas Colonialism's Culture 1994:1), a residual cultural imperialism (Said Orientalism 1978; Culture and Imperialism, 1994) and the psychic dimension of its informing psychology still persist (Fanon Black Skin; White Mask, 1956; Memmi Colonizer and the Colonized $^{l 7}$, 1965; Mannoni Prospero and Caliban, 1964; Nandy Intimate Enemy, 1983). Colonial economic hold is perpetuated in the form of 'late capitalist' erosions of capital and goods to the centre. Frederic Jameson ("Periodizing the 60s" 1984) succinctly exemplifies this by noting "the replacement of the British Empire by the International

\footnotetext{
${ }^{17}$ In his 2006 sequel to the 1965 critique titled Decolonization and Decolonized, Albert Memmi suggests that the continued impoverishment and political instability of the postcolony is the fault of the former colonized since the colonizer has moved out. Like joins Jean-Franscois Bayart in The State in Africa: Politics of the Belly (1993) and Patrick Chabal and Jean Pascal Daloz in Africa Works: Disorder as Political Instrument (1999), he performs a scission between colonialism and its after-effects and views the decolonised state as 'natural.'
} 
Monetary Fund" (184). He continues that "decolonization historically went hand in hand with neo-colonialism, and that the graceful, grudging or violent end of an old-fashioned imperialism certainly meant the end of one kind of domination but evidently also the invention and construction of a new kind"18 (Ibid). A consciousness of those neo-colonial effects is what informs Nicolas Thomas' assertion that "[...] an assumption that colonialism is primarily a social form of the past entails definitions that are too specific for example, that it is the formal rule of a dominion by a metropolitan country" (op cit 1994: 16).

Thomas is invoking the all-pervading socio-political, economic and cultural implications involved in domination and conquest, and their resilient echoes in the present. According to Moore-Gilbert (Postcolonial Theory 1997) contemporary “[...] relations of domination and subordination $[\ldots]$ have their roots in the history of modern European colonialism [which] continue to be apparent in the present era of neocolonialism" (12). And as Said notes in Culture and Imperialism (1994) the hegemonic 'system' within which colonialism inhered went further back ${ }^{19}$ than "the age of empire" (58) even though it is often denoted by historians as beginning "in 1878" (sic; 58) with 'the scramble for Africa. ${ }^{20}$ "A closer look at the cultural actuality reveals a much earlier, more deeply and stubbornly held view about overseas European hegemony" (58). Those

\footnotetext{
${ }^{18}$ See also Masao Miyoshi's "Borderless World?" and Arif Dirlik's "Global in the Local" in Wilson \& Dissayanake Global/Local 1996: 97; 31) for a discussion of a perseverance of Western imperialism in the contemporary postcolonial period.

${ }^{19}$ One could say that it predated, superseded and enabled slavery, of which colonialism is a mutation. They, at least, reach so far back as 1350 when Europe began to imagine Africa (Hochschild King Leopold's Ghost 1998: 1).

${ }^{20}$ Said goes further to explain that "[...] we can locate a coherent, fully mobilized system of ideas near the end of the eighteenth century, and there follows the set of integral developments such as the first ever great systematic conquests under Napoleon, the rise of nationalism and the European nation-state, the advent of large scale industrialization, and the consolidation of power in the bourgeoisie." (1994: 58)
} 
views were systematised in "Western fiction, historical writing, and philosophical discourses of the time" (58).

One would expect that a system, which was built over centuries and was instituted for centuries more, would be equally as enduring in its contemporary effects. In discussing the implications of aesthetic form, history and knowledge production in empire building, Said discourages "the practice in the West since Emmanuel Kant to isolate cultural and aesthetic realms from the worldly domain" (58). One could say that it is in that regard that Bhabha insists: "postcolonial criticism bears witness to the unequal and uneven forces of cultural representation involved in the contest for political and social authority within the [post] modern world order"21 ("Postcolonial and Postmodern" in Location of Culture, 1994: 245).

In the colonial period, even before the advent of television and other media, cultural representation through other aesthetic forms like texts - especially - or visual arts was invariably important in how the 'native' and his or her culture was perceived or in how demonic images of the Other (Achebe An Image of Africa 1975; Curtin Image of Africa, 1964) was constructed. This subject is the major thrust of Said's foundational postcolonial critique, Orientalism (1978), of which he remarks himself that Culture and Imperialism is "a sort of sequel" (Culture and Imperialism 54) in its themes. While the first work concerns how the Occident fetishsized and demonised the Orient in Western imagination, the second one details the native's aesthetic occlusion and misrepresentation in eighteenth and nineteenth century European novels and, latterly, in nineteenth and twentieth century American narratives and discourses.

\footnotetext{
${ }^{21}$ The chapter in question is significantly sub-titled, "The Survival of culture," that is, of pre-colonial or Third World culture.
} 
In those two critiques of modernism by Said the arguments are similar and the goal the same - namely to display "how [European] culture participates in imperialism yet is somehow excused for its role" (107) and to show that "[w]hen it came to what lay beyond metropolitan Europe the arts and the discipline of representation [...] depended on the power of Europe to bring the non-European world into representation, the better to be able to see it, to master it, and, above all, to hold it" (99). That mastery, coalescing in subjugation and rule and enabled by European "high or official culture" (107), translates into cultural subordination in contemporary times due to the pervasive hierarchies established in the past. "The modern history of literary studies has been bound up with the development of [Western] cultural nationalism, whose aim was first to distinguish the national canon, then maintain its eminence, authority, and aesthetic autonomy" (316).

The residues of cultural imperialism can be said to contribute to a devaluation of the African space as a source of 'culture or civilization,' and to a contemporary normalization of those perceptions in muted ways - especially through $20^{\text {th }}$ century Western media. In a journal dedicated to probing the theoretical shortfalls of the discipline, Interventions (Vol. 1.1ff 1998), Kadiatu Kanneh makes an observation about postcolonialism's penchant for a general theoretical "silence" ("History, 'Africa' and Modernity" 31) about Africa: "Africa remains a problem because its interior appears to crouch outside the obsessions of modernity" (31). In the matter of contemporary media representation, Kaneh has this to say: "The [twentieth century] anticolonial struggles and internecine strife that characterize Africa's place in the media and the frequent footage of famine, AIDS and 'natural' disasters perpetuate the image of the Dark Continent ( $31 \mathrm{ff}$ ). 
It can be said that that theoretical silence is invariably related to historical imperial cultural diminution of that continent through a discursive strategy, which Said, in the works mentioned earlier, goes to a great length to unpack as an "imperial motif" (Culture and Imperialism 63) preceding colonialism, and emphasised in nineteenth century European fiction about the colony. He notes that the negating cultural representations of the Other in the colonial library - exemplified in such works by accomplished European writers from Charles Dickens, Jane Austen, Joseph Conrad to Rudyard Kipling and R.L. Stevenson - are equivalent, in their 'silences' about the Other, to an Hegelian "peoplewithout-History" (Eric Wolf 1992 qtd. in Culture and Imperialism 64) mode of narration. Other critics have noted the importance of cultural representation to the constitution of colonial and colonized subjectivities or aesthetics before and after contact between both.

Elleke Boehmer (Colonial and Postcolonial Literatures 1995) emphasises the symbioses between textuality and Empire, noting how the one actually author(ises) the other; 'authorises' colonial administration, the possession of foreign land, and the legitimation of imperial activity through "political treaties, diaries, acts and edicts, administrative records, and gazetteers, missionaries' reports, notebooks, memoirs, popular verse, government briefs, letters 'home' and letters back to settlers" (13) and racist novelisation of distant places. She maintains that Victorian English identity at home was shaped by Othering imperatives in writings about the 'dark' outposts of the British Empire. Kanneh succinctly expresses the confrontation between self and Other, with particular reference to Africa thus: "Africa's historical role in the formation of modernity, particularly as a discursive site for ideologies of race, humanity and progress, 
is one that helped to forge Europe's idea of itself, as well as to lay the foundations of modern Black identities" ("History Africa and Modernity" 32; my emphasis).

It is logical that, in the move towards modernity, the type of colonial activity a country or continent has experienced defines contemporary cultural valuation to a large extent. Colonialisms of the core, semi-periphery or periphery (Wallerstein, World Systems Analysis 2004) respectively have resulted in a modern cultural power relationship, which is progressively subordinating relative to the distance from an originally colonising centre, with a centre-periphery equation being the extremes. This is why literatures from Australia, Belgium, New Zealand or Ireland and Nigeria, Cameroon, Botswana, Liberia or Ghana might all be in the margins relative to say British, French, German or American literature, nevertheless the first set of examples of small literatures is in a relationship of apparent relative competition to the dominant, while the second set is in an obvious situation of being dominated perpetually.

It is instructive that Casanova's historical discussion of contemporary literary prestige places Western Europe (in literary-cartographical terms) - Paris, London, Germany, Italy or Belgium and so on, with its cultural satellites (America, Canada or Ireland, for example) - at the centre of her world republic of letters. In this arrangement those literary capitals, which were also once 'colonising capitals,' become centres of a global canon towards which the small literatures from the formerly colonised periphery tend with different degrees of success. This is because "these [global and local literary] spaces have slowly establish[ed] hierarchies and relations of dependency that over time create a complex and durable design" (Republic of Letters 83). African literature, 
emerging out of a colonialism of the periphery as it does, is arguably at the bottom of those hierarchies of valuation, or of access to resources for cultural production.

Moreover the historical effect of "colonialism's culture," as Thomas refers to the imperialism of cultural domination, results in a contemporary configuration of a global literary canon that has a "Greenwich meridian of literature" (Republic of Letters 88) as a central reference point for all contending writers and literatures. That 'equator' is invariably always located in former colonial capitals. "The aesthetic distance of a work or corpus of works from the centre may $[\ldots]$ be measured by their temporal removal from the canons that, at the precise moment of estimation, define the literary present" (88). Juxtaposed with Anglophone African literature, that defining canon is Britain's "great tradition," (F.R. Leavies, 1948) with its "Master's pieces" (Gates Loose Canons, 1992: 17ff). However, canon formation is never a close-ended process. Casanova insists that we do not reduce canonicity to a simple binary opposition of dominated and dominant. We should think in terms of "a continuum, for the many forms of antagonism to which domination give rise prevent a linear hierarchy from establishing itself" (Republic of Letters 83).

The inconclusive nature of the global canon is precisely why it is being reshaped by the inclusion of literary works from the global South - albeit within a subordinating "literary order of symbolic representation" (Hassan "Canons after Postcolonial Studies" 2001: 298). Such inclusions encompass writing by contemporary third generation Nigerian writers. Examples from Anglophone Africa, with emphasis on Nigeria, are novels, plays and poetry by first generation writers like Chinua Achebe, Wole Soyinka, Christopher Okigbo and John Pepper-Clark, the second generation writer, Ben Okri, and 
latterly members of the third generation such as Chimanada Ngozi Adichie, Helon Habila, Chris Abani, Bandele Thomas and so on, and their contemporaries in Francophone Africa - Alain Mabanckou, Calixthe Beyala, Abdourahman Waberi or Patrice Nganang, amongst others. The above writers, as far as global visibility is concerned, owe their consecration to institutional literary patronage through, and from, the centre.

While such inclusions are an inevitable result of the globalisation of culture and the concomitant development of a world literature (What is World Literature? 2003) they are, however, subject to the symbolic violence and the struggle within the field of cultural production. In discussing the inequality involved in the production, consumption and dissemination of African literature Isidore Diala ("Writers' Burden" 2008) quotes: "All canons rest on exclusion; the voice they give to some can be heard only by virtue of the silence they impose on others. But it is just not a silencing by exclusion; it is a silencing by inclusion as well: any voice we can hear is by that very fact purged of its uniqueness and alterity" (Attridge 1992: 226 qtd. in Diala 134). That observation is very pertinent to the exclusion of a large percentage of African cultural production, including third generation Nigerian texts from the global canon and the inclusion of token representatives such as those detailed above.

Canonical silence can be imposed from the centre because, the literary prestige that has accrued to the literary capitals of the former colonising metropolises constitute them as contemporary arbiters of literary taste and value for (and within) the margins, and as disproportionately overwhelming repositories of symbolic, cultural or economic capital. Transnational literary establishments and validating academic institutions - "agents of 
legitimation" according to Graham Huggan (Postcolonial Exotic 2001: 5) - decide which African writers enter the global literary canon. These include, but might not be limited to, the already consecrated "writer" (5), metropolitan publishers, literary agents, editors, or literary judges and, literary awards institutions such as Britain's Commonwealth Foundation ${ }^{22}$ and the Book Trust (107) or France's Goncourt Literary Society ${ }^{23}$ (Société littéraire des Goncourt), who administer a range of prizes for writers from their former colonies. Quoting Frow, Huggan includes Western "booksellers, publishers, reviewers and, not least, individual readers and "valuing communities"' (Frow 1995 in Huggan 2001:5).

The importance of metropolitan capitals in global canon formation is emphasised by the fact of Parisian pre-eminence in modern cultural globalising processes. This has been noted by many scholars and has led to Walter Benjamin (1969) describing that cultural megalopolis as "capital of the $19^{\text {th }}$ century." And London was the "other capital of the nineteenth century" as remarked by Evan Horowitz ("Capital of the Nineteenth Century" 2010: 112) in genuflection to Benjamin, and in discussing the influence of a precocious English industrialisation on literary modernity as reflected in the French symbolist, Charles Baudelaire's poetry. ${ }^{24}$

\section{Exclusionist Implications of the American Canon Debate}

A brief discussion of the American canon debate of the 1980s will be useful in order to further demonstrate how historical geo-political power relationships coalesce in the

\footnotetext{
${ }^{22}$ See http://www.commonwealthfoundation.com/>. Accessed on June 182012.

${ }^{23} \mathrm{See}<\mathrm{http}: / / \mathrm{www}$.academie-goncourt.fr/>. Accessed June 18, 2012

${ }^{24}$ According to Horowitz: "The strong association of Paris with modernity, and of Baudelaire with both, draws a good deal of its force from the work of the German philosopher and social critic Walter Benjamin" (2010: 112). See also Rolf J. Goebel. "Paris, Capital of Modernity." Jstor. Monasthefte Vol. 90.4. (1998): 445-464.
} 
present to limit literatures that are minor and whose minor status are, in the first place, a function of those historical relationships.

The importance of the American canon debate for small literatures is that after the Second World War America took over the erstwhile global cultural ascendancy of Great Britain. The nascent imperialism of America, apart from its near-extermination of native Americans and, massive involvement in slavery, is indicated in a regime of representation in its $19^{\text {th }}$ century literature "contemporary with British and French work" (Culture and Imperialism 63) of the period "which shows a peculiarly acute imperial cast" (63). The twentieth century shift of imperial power to the USA occurred after "the age of Europe" (West "Cultural Politics" in Ferguson et al 1990: 20), which began in 1492 and ended in $1945 .^{25}$ As an added nascent Western culturally dominant region of the North at the time - especially opposed to the global south - the canonical preferment of the American academy as an institutional site had and still has relevance for the development of postcolonial literatures.

It is not the purpose here to give an elaborate account of the canonical debate or the details of the various responses that have been generated since elsewhere. I will, however, touch on those points in these enquiries that are germane to this dissertation, especially as circumscribed by the historical politics of difference broadly referenced at the outset. Since John Guillory's positions, which were expanded in Cultural Capital, have immediate bearing on that politics, I will engage him as a starting point and generate my positions based on his and other responses against which his views will be measured.

\footnotetext{
${ }^{25}$ It may be said that the American Empire itself ended on September 11, 2001 after the World Trade Centre bombings since that event propelled it into responding military actions abroad, which hastened its depletion and decline. That empire, it can be argued, lasted fifty-six years from 1945, making it the briefest ever as China gains ascendancy.
} 
Susan VanZanten Gallagher ("Pedagogical Canons" 2001) maintains that the canon debate was initiated by a controversy over Princeton University's "Western culture course in 1987" (53; see also Cultural Capital 31). Nevertheless scholarly engagements of it were carried out before that time in two special issues of the journal, Critical Enquiry (1983 Vol. 10.1; 1985 Vol. 12.1), the first being tiled "canons" and the second, "Race, Writing and Difference." Those special issues raised the question of whether noncanonical works ought not to be included in university curricula and by what modalities, if at all. This, of course, meant that discussions would devolve around motivations for value judgments and their formation - as they did.

The central argument in Cultural Capital is that class and gender disparities are responsible for canonical inequity. But if one were to truly historicise the global canon and its conversation with minor literatures from the global South or within American subculture itself, race would have equal, if not more weight, in matters of value judgements. Guillory discusses the historical difference circumscribing canon formation only in immediate real-political and "social identity" (3) terms, rendering his understanding of difference ahistorical. The "[...] politics of canon formation has been understood as the politics of representation - the representation or lack of representation of certain social groups in the canon" (5) modified by race, class and gender. He accounts for history in a Eurocentric manner, referencing an "early modern European period" (16) and transposing the European social inequality of that time unto contemporary American society, to account for why minorities are not adequately represented in the canon.

For instance Guillory gives no account of the impact of slavery in the shaping of the category of class that he rarefies above all others. He goes on to say that, "the 
problem of canon formation is best understood as a problem of the distribution of $[\ldots]$ access to the means of literary production. The 'means' in question are provided by the school, which regulates and thus distributes cultural capital unequally" (original emphasis ix). While he rightly understands the possibility of unequal access to education as a social fact, he occludes an important reason, amongst others, for that inequality - that is, race. Despite Guillory' privileging of literacy as the basic requirement towards canonicity and his recognition of a "systemic regulation of reading and writing" (18 original emphasis) in the socious, he does not trace this to its roots in slavery - at least as far as African America is concerned. Slavery ${ }^{26}$ is just one instance of the historical fact of "the construction of ethnic hierarchies [which] has always defined [America's] cultural politics" (Hall "Black Popular Culture" in Morley and Chen, 1996: 466). Slavery and colonialism are, in a manner of speaking, synonyms for one another. Literatures from those cultures or subcultures that have been subjected to those two experiences are always going to be canonically unequal at the centre. This is the connection between the American canon discussion to the relative silencing of African and Nigerian postcolonial literatures.

In essence Guillory is saying that matters of canonicity should be left to social forces and should not be interfered with by "liberal-pluralist" (4) Affirmative Action. He traces the idea of a concrete reality called the 'canon' to a 'fallacy' in which liberal critics

\footnotetext{
${ }^{26}$ Slaves were denied access to reading and writing in antebellum America. "Before the establishment of Liberia, few freedmen had the opportunity for an education. Education for Blacks was contested and those individuals, black or white, operating schools for Blacks-even in New England-suffered hostility and oftentimes physical abuse from outraged whites. Education for slaves was generally proscribed and after the slave rebellions of the 1820 s and 1830 s, especially Nat Turner's rebellion in 1831 , most of the southern states passed codes explicitly prohibiting the teaching of reading and writing to slaves. Nat Tumer was literate and the connection between reading and writing and rebellion was well recognized. For that reason, these skills were championed by Abolitionists and abhorred by slaveholders and negrophobes. (Livingston "Liberia College, 1850-1900" 1976: 247)
} 
conflate "an imaginary totality of works" (30 original emphasis) with a physical and concrete presence. Disqualifying the idea of a 'monolithic' literary canon, he notes that it is the "syllabus as an institutional instrument" (30) rather than personal judgements "about individual works" (30), which results in "the canonical and the noncanonical" (30). Although, one might argue that the 'institution' is made up of individuals who are invariably the locus of personal judgements. In a different context outside Critical Enquiry but following Guillory, Gallagher ("Pedagogical Canons" 2001) makes a distinction between "an imaginary canon" (53) and, a "pedagogical canon" (54). The latter is a "concrete list" (54) drawn up when an "instructor creates a personal pedagogical canon for each course by means of selecting a reading list" (54). Texts that are often likely to be found on disparate university reading lists then form a "wider pedagogical canon," (54) that is "empirically verifiable" (54).

While the main premises of the above discussions are valid on face value, their sum carries an internal contradiction in the distinction imposed by the conservative arm of the debate between a concrete and an illusory canon. A "wider pedagogical canon," through the force of its repetition amongst different Western academic institutions "over a relatively extended period of time" (Cultural Capital 31), begins to resemble a global, all-pervasive literary canon, otherwise presented as non-existent and imaginary. For example, to emphasise his central argument about the marginalisation of Native American literature within the American canon, Arnold Krupat invokes Roland Barthes' comment in "Reflexions sur un manuel:" "The 'teaching of literature,' $[\ldots]$ is for me almost tautological. Literature is what is taught, that's all" (Barthes, 1970: 170 in "Native American Literature" 1983: 146). Even Guillory himself asserts that "changing the 
syllabus cannot mean in any historical context overthrowing the canon because every construction of a syllabus institutes once again the process of canon formation" (31; original emphasis). Understood differently, the pedagogical canon and the literary canon are one and the same. The idea of an 'imaginary canon' is then itself imaginary. As Mark Eaton suggests: "the pedagogical canon is not as different from the imaginary canon as Gallagher thinks" ("Imaginary versus Pedagogical Canons" 2001: 308).

Moreover, irrespective of the distinction between an imaginary canon - in the sense of an 'absent object' - and the pedagogical canon, where there is an empiric list, choices still have to be made and judgments about value based on literary taste will inform those choices. It is during that process that the cultural conditioning and ideological and class interests of the instructor as a subject of history come into play. This is why Walter D. Mignolo has proposed the need to "distinguish between the vocational and epistemic (or disciplinary) aspects of canon formation" ("Whose Canon?" 1991:1). A vocational canon represents the investments of the instructor as instructor and as a member of a specific ethno-canonical tradition that is unique in itself. Conversely the epistemic canon consists of works organised in a hierarchical scientific analysis of texts. This is similar to the situation within the literary/pedagogical canon under a disciplinary area of study.

The vocational and epistemic might appear tangentially similar to Gallagher's distinction between an "imaginary" and a "pedagogical" canon, but not quite - if we consider that both the imaginary and pedagogical still meet on the ground of an allencompassing 'literary canon' that is studied hierarchically. Perhaps there could be a resolution if one were to follow Mignolo's suggestion that "[a]t the vocational level, a literary canon should be seen in a curricular context (What should be taught and why?). 
At the epistemic level, canon formation should be seen in the context of research programs, as a phenomenon to be described and explained" (12). This leads to Mignolo's critique of Krupat's project for the inclusion of Native American literature into the American canon "at both the vocational and epistemic levels. He suggests a unique crosscultural ethno-canonical approach: "[A]merican Indian literature could be conceived in terms of its own canonical status and not necessarily in the context of the 'official' American literary canon" (7).

Nevertheless Krupat's Foucauldian observation on the subject is still valid for American Indian, African or any other 'minor' literature. He insists that the canon, "[...] like all cultural production, is never an innocent [pedagogical] selection of the best that has been thought and said; rather it is the institutionalization of those particular verbal artefacts that appear best to convey and sustain the dominant social order" (Krupat op.cit.146) ${ }^{27}$. This is important considering the usual enlargement of the epistemic or disciplinary level over and above the vocational in canonical matters. Mignolo emphasises his solution for the appreciation of minor literature further, noting that "[a]cross cultural boundaries, a canon should be seen as community-relative and not in hierarchical relation to a master canon, nor within an evolutionary model in which the canonical examples become the heaven to which literature aspires and the yardstick for hierarchical organization" (6).

The problem with Mignolo's panacea, as I see it, is that even the categories of the vocational and the epistemic will invariably involve selections based on value

\footnotetext{
${ }^{27}$ Krupat's "the best that has been thought and said" echoes almost word for word, that famous postulation of Mathew Arnorld's "the best that is thought and known" (in Said 1994:45) with regards to literary culture and the canon that is built around it. Edward Said (ibid.) also points to this ideological formulation of Arnold's in discussing the same Eurocentric construction of what constitutes 'culture.'
} 
judgements. And a cross-cultural approach to canonisation will always imply a hierarchisation of cultures. In short there is always going to be a master canon or master canons. This highlights the precise difficulties African or any other minor literature will have to contend with as long as historical power structures are in place. The pedagogical/literary canon is, consciously or otherwise, pressed towards inculcating and re-emphasising those structures. In that manner historically constructed hierarchical subject positions are reinforced. In Krupats words, "[w]hat the pedagogical canon includes from the past and from current production generally and substantially works to ratify the present and to legitimate an established hegemony" ("Native American Literature" 146).

In an effort to dismiss arguments about inequality in canon formation Guillory unwittingly confirms Krupat's views about canonical hierarchies and hegemony. The former insists that a basis does not exist for comparing sacral and secular canon-forming processes. However the subject forming or objectifying imperatives of any type of canon formation ultimately renders their informing processes similar - even if not in detail but in general. Ironically Guillory's example of the Princeton University syllabus, which enlarged the canon debate, clearly locates the Bible at the top of the reading list of that university's literature or humanities course in 'Western Civilization' as a "required" (Cultural Capital 30) 'pedagogical' rather than sacral text. Princeton is, after all, a secular university and not a Seminary for the training of priests.

Specifically Guillory asks "whether the process by which a selection of texts functions to define a religious practice and doctrine is really similar historically to the process by which literary texts come to be preserved, reproduced, and taught in schools" 
(30; my emphasis). On the one hand, it is noteworthy that the biblical canon is arrived at through the exclusion of less privileged texts according to Gerald L. Bruns ("Canon and Power" 1984), and on the other, the resulting sacral canon, when reduced to its human agency, can be viewed from a secular perspective as nothing other than literature. And "Literature, in the meaning of the word we have inherited [from the eighteenth century], is an ideology" (Eagleton Literary Theory 1983: 22).

\section{The Convergence of Sacral and Literary Canons as Ideology}

The ideological nature of the text, sacral or otherwise, is evident in the pedagogic uses to which the Bible has been put, and is still being put - at Princeton, for example. Colonial history is replete with the deployment of the Bible as a secular pedagogical text. Christian proselytization was indirectly introduced into the Indian education system by colonial authorities towards the pacification of the 'native.' Although "the British government officially remained committed to a policy of religious neutrality" in India, it distilled Christian values through "government schools [that] prescribed spelling-books for teaching English [as language], [while those] books contained passages at variance with polytheism" (Viswanathan Masks of Conquest, 1989: 78) - which was and still is the cultural norm in India. The introduction of religious indoctrination was a result of missionaries' civilizing zeal, which insisted on introducing direct Christian teaching in mission schools.

The ambivalence engendered in the colonial government due to fears of "native" resistance to direct Christian instruction" (76) were resolved by introducing English Literature, distinct from 'language,' as a course of study because it was believed that 'the new ideas obtained by the study of English Literature will undoubtedly weaken, if not 
destroy, superstitious prejudices [...]" (Reports and Observations on the Indian Mission 1872: 115 qtd in Viswanathan 76). As a pedagogic tool in the Indian school curriculum the Bible resembled English literature because of their common and "vast repository of Christian values" (93). She goes further to explain that "[t]he importance of English literature $[\ldots]$ as the source of moral values for correct behaviour and action $[\ldots]$ represented a convenient replacement for the direct religious instruction that was forbidden by Law" (93).

It is remarkable that the "first canonization of note for western [sic] culture seems to have been that of the Hebrew Scriptures" (Adams "Canons" 1988: 748). The role of the Bible in the native's coercion, tutelage and as a 'civilising' tool, and an instrument for the native's cultural misrepresentation, was simply a precursor for the elaboration of subject forming imperatives in Judeo-Christian culture generally and in Western canonical philosophical, exegetical or literary texts and travelogues, epistolary forms, colonial government documents and statues of governance. This is in keeping with that Western academic institutional penchant, described by Barbara Herrnstein Smith, ("Contingencies of Value"1983) as the "essentially conservative and didactic mission of humanistic studies" (2). To exemplify that, there could not have been slavery without the racial interpellation in the Biblical canon of the black enslaved as those 'cursed' as the children of Ham (Whitford The Bible and the Justifications for Slavery 2009; Goldenberg Race and Slavery in Early Judaism, Christianity, and Islam 2003). That process of "naming" (Adesanmi "Comtemporary Theorising" in The Study of Africa Vol. 1 Zeleza, 2006:108) is a 'worlding,' which equated the mythological with the concrete and gave legitimation to structures of domination and subjugation based on demonised alterity. 
"Naming precedes and begets (mis)representation which, in turn, is deployed as justification for all forms of violence that have been masquerading for [more than] five centuries as a mission civilisatrice" (original emphasis 108).

The moment of the convergence of the biblical and literary canon in England was as a result of "scientific discovery and social change" (Literary Theory 23) in English society. The period witnessed a failure of the hitherto coercive power of religion as an ideological instrument for maintaining class hierarchies and for acting as "social cement" (23). To control a new, rich and morally corrupt mercantile class, which sprung up due to the industrial revolution, and the working and lower classes and women, the failing grip of religion was replaced by the “' 'softening' and 'humanizing' effects of English [Studies which], within the existing ideological stereotypes of gender, was clearly feminine" (26).

The conflation of English studies with femininity is important. Ashis Nandy's (The Intimate Enemy 1983) study of the masculinity of the colonial project identifies its transference of Victorian sexism and age-ism - "institutional discrimination in Britain" (4) - to the Indian colony in stereotyping the 'native' as feminine, childlike, a tabula rasa, lazy and so on. In colonialism's "style of managing dissent" (3) at home or in the colony the Victorian period produced a "cultural consensus" (4) in which "socio-economic dominance symbolized the dominance of men and masculinity over women and femininity" (4). In the nineteenth century, English, according to Eagleton, was considered "[...] a suitable subject for women [...] and the second- and third-rate [feminised] men [...] who become schoolmasters" (Gossman "literature and Education" 341-2 qtd. in Literary Theory 27). Literature was introduced because "[1]ike religion, literature works 
primarily by emotion and experience, and so was admirably well-fitted to carry through the ideological task where religion left off" (26). That task was a "pacifying influence, fostering meekness, self-sacrifice and the contemplative inner life" (23; original emphasis).

Viswanathan notes "the irony that English literature appeared as a subject in the curriculum of the colonies long before it was institutionalized in the home country" (op. cit. 3). She comments on the brief nod which Eagleton and some other critics give to the colonial roots of English and emphasise its function as a discursive tool. "As early as the 1820 s, when the classical curriculum still reigned supreme in England, [...] English as the study of culture and not simply the study of language had already found a secure place in the British Indian curriculum" (Masks of Conquest 3). In essence the discipline of English Literature is an ideological minefield from its inception and it has always placed the Other literature in a programmatically subordinate position such that any new body of literature, like Nigerian writing, entering the field struggles for visibility against an already established master canon. Graham Huggan insists, "English literature is highly effective as an instrument of imperial power" (Postcolonial Exotic 113). It compares as a structuring device beside 'Literature in English.' According to Karin Barber ("African Language Literature" 1995), "[i]n the British colonies, the imposition of English language and English literature represented claims to the superiority of British civilization which were ultimately backed by force" (4).

Since the historical "formation" (Mignolo "Whose Canon?" 3) of the Bible as a sacral canon and its "transformation" (3) as a collection of secular pedagogic literary texts are both ideologically motivated, it is not possible to dissociate it from those "most 
intimate relations with questions of social power" (Literary Theory 22) which are intrinsic to literature as noted by Eagleton in his discussion of "the growth of English Studies in the later nineteenth century" (22) in England. It is instructive that Bruns' analysis of historical biblical canon formation ends with the conclusion that it is a selection of texts, albeit sacral, based on group interest and that, in short, "canon is not a literary category but a category of [social] power" (1984: 478). In spite of Hazard Adams' ("Canons" 749ff) questioning of a preponderance of the 'power criteria' as an overwhelming critical tendency over a 'literary criteria' in the canon debate, modernity's textual representational oeuvre, it can be argued, still proceeded out of 'power hierarchies' in which "[t]he third-world idea has been created by a knowing subject which, in the very act of creating the notion, located itself in the first" ("Whose Canon?" 2).

Due to the secular convergence of the Bible with 'literature' as a pedagogic category one is forced to conclude that Guillory's effort to draw distinctions within historical processes of canon formation - biblical, literary/pedagogic or 'imaginary' - is problematic. Beyond questions of contemporary social, real-political representation and equality and apart from the apparent intent to educate, the canon, whether sacral or secular, is a tool for social control, the formation and maintenance of subject positions and cultural power structures. Moreover, the pedagogical canon is an ideological tool if we remember that the 'school,' as a site where canons flourish within programs of study and their allied curricula, belongs to that discursive formation, which Althusser has referred to as the ideological state apparatus (Lenin and Philosophy 1971). 


\section{The Limits of Cultural Capital}

The history of the introduction of Western education and critical praxis into the former colonies conflicts with investments in an exclusive power of arrest in "school culture" (Amoko "Canonicity, Citizenship and the Idea of Africa" 2001: 23) as an assured source of cultural capital in canonical matters. The conflict resides in the essentialising of the formal classroom as the main locus of that capital's plenitude, and a de-emphasising of its informing historical social conditions. The first hindrance to cultural capital in the periphery is that of a historical subordination of colonial and postcolonial school culture to the metropolitan. A. O. Amoko clearly occludes that crucial fact when he avers that "essentially the same rarefied system of literary coherence, that is to say, same codes for decipherment, modes of inquiry, rules of evidence, and protocols of reading govern programs in English Literature/Literature in English everywhere in the English-speaking world" (23).

Colonial African universities, initiatives of missionaries and the colonial government, were modelled at their inception after metropolitan examples, of which they were structural, pedagogical and curricular "appendages" ("Contemporary Theorising" 104; see also Zeleza "African Studies and Universities" 2009: 114). The impact was such that in Nigeria "[T]he national curriculum was British [from the colonial era] until the beginning of the 1980s, when a new National Policy on Education brought about an educational tradition that largely projects the (sic) Nigerian culture" (Na'Allah, "Culture and Language" in Afolabi, 2003: 189).

In a pedagogic re-mapping of the continent (see "African Studies and Universities" 110), an age-old European mental or 'virtual' geo-political demarcation of 
the continent was actualised in the partition of Africa in 1884 and translated into symbolic articulations of zones of hermeneutic, epistemic, linguistic political and hence socio-cultural rule through colonial education, all subsumed under capitalism. Walter Mignolo, in an essay exploring the same question in relationship to the colonial roots of the Latin America University, opines that "the accumulation of money, in the constitution of Europe, the West, or Western civilization, went hand in hand with the accumulation of meaning" ("Role of the Humanities in the Corporate University" 2003: 98). And meaning is conditioned by language, hence, the colonial imposition of English Language and its knowledge economy, including its literatures (Barber and Furniss "African Language Writing" 2006:1-14; Barber "Three Colonial Yoruba Novels" 2007: 108-129; Barber "African-Language Literature" 1995:3ff). "The expansion of linguistic (or linguisticcultural) areas $[\ldots]$ constituted a sort of extension of European national literary space (Casanova 116). In 1978, Ali Mazrui described the African university as a primary locus for the promotion of Western civilization (see Brock-Utne "African Universities and African Heritage" 1999: 91). This imperialisation of colonial and postcolonial school culture complicates the idea of its being an automatic repository of cultural capital.

Cultural production by an 'educated' writer from the periphery, is ultimately still subordinated to that of his counterpart from the metropolis due to the historical inequality between local and global school systems. Moreover literary production, which emanates from the periphery compared to that from the centre, is less likely to receive global visibility despite similarity in their enabling school cultures. As noted by Barbara Herrnstein Smith in particular reference to the American academy, in matters of canonisations the Western academy is duty-bound to "honor and preserve the 
[mainstream] culture's traditionally esteemed objects - in this case, its canonized texts and to illuminate and transmit the traditional cultural values presumably embodied in them" ("Contingencies of Value" 2).

Another problematic where access to cultural capital vis-à-vis literary production is concerned is that not all cultural producers, anywhere in the world, acquire formal education, and that some are autodidacts or even uneducated. A cursory survey of literary and artistic history will easily prove that many a great and successful cultural producer did not necessarily come to their work with the weight of a formal education or rigorous professional training behind them. There is a litany of Western writers and artists who never had any classroom education or that specialized professional training that has become only very recently common, especially in creative writing programs of Western Universities and Colleges. It must be said also that formal education alone or its combination with a creative writing training does not guarantee success or true ability at literary production without an innate or a native talent and imagination. I will exemplify this through an appraisal of Nigeria's Amos Tutuola, in keeping within the geographical purview of this dissertation.

With practically no formal education, Tutuola, who was near illiterate, went on nevertheless to become the first Nigerian to be published in English in the metropolis and to achieve global visibility. Faber and Faber issued The Palmwine Drinkard (PWD) (Tutuola 1952) to an initial feverish critical acclaim in London. His second novel, My Life in the Bush of Ghosts, engendered the same appreciative and warm metropolitan reception, even if there was some critical reticence with his subsequent works. Bernth Lindfors' Critical Perspectives on Amos Tutuola (1975) is a detailed aggregation of 
informal reviews and scholarly critiques of Tutuola's oeuvre. Journal commentaries on PWD are mostly of great encomium on both sides of the English Channel. In the post-war period of the 1950s this previously unknown African writer was a kind of Wunderkind.

Accomplished writers and critics in England from Dylan Thomas to Kingsley Amis and V.S Naipaul wrote glowingly about Tutuola's work in prestigious institutional publications such as the London Observer, The Spectator, The Times Literary Supplement, West Africa, New Statesman and Nation, The Listener, The Reporter, West Africa Review and London Magazine. Across the English Channel the same paroxysm of praise prevailed in The New York Times Book Review and The New Yorker (Amos Tutuola 1ff). No less important a literary personage than T.S. Elliot had read the manuscript of PWD as an editor with Faber and Faber and given its eventual publication his approval.

The global acclaim of PWD at the time had nothing to do with the author's possession of cultural capital. Amos Tutuola had no 'classroom education' in the strict sense. $\mathrm{He}$ "[...] began his rudimentary schooling [at the primary level] at the age of fourteen and it was broken off when he was nineteen, in 1939 (Booth Writers and Politics, 1981: 67). Although Lindfors account (Amos Tutuola 275) suggests that Tutuola had six years of schooling compared to James Booth's implied five, the important fact is that the author did not speak or write English in its standard form or intelligibly. Irrespective of its critical acclaim "PWD provoked controversy for its episodic rendering of Yoruba folktales in nonstandard English" (Low "The Natural Artist" 2006: 15) 'Nonstandard English' is a euphemism for the garbled prose of PWD. Apart from the fact of his knowledge of Yoruba cosmogony and "oral lore" (Lindfors Early Nigerian Literature 
1982: 32) and of his being "a story teller [...]" at school (Writers and Politics 67) Tutuola's only 'education' was his private readings of works in a similar fantastic genre such as D.O. Fagunwa's oeuvre in the Yoruba language and the Arabian Nights (Amos Tutuola 31ff).

Faber and Faber's initial fascination with Tutuola's stories about an unearthly spirit world lay in the anthropological force of the work, emphasised by its strange, ungrammatical and syntactically tortuous prose and quaint expressions. The protagonist of PWD, the connoisseur of palm wine, seeks to resurrect his inimitable tapper by embarking on a dangerous ten-year journey through the forest and the netherworld - a phantasmagorical space peopled by strange inhuman, half-human creatures, spirits, elves and ghommids. His tapper had died, having falling off a palm tree while engaged in tapping wine. We learn much later in the narrative when the palm-wine 'drinkard' encounters his "tapster" (PWD 96) in "Deads' Town" (96) that the revered tapper, by his own admission, had become giddy from drinking his own brew and had fallen of the palm tree, being thus dispatched to the world of the dead. A short passage should suffice as example of the 'drunken' prose. However a little elaboration is necessary to appreciate a pattern and the progression of the text to its strange resolution:

When it was $8 o^{\prime}$ clock in the morning, then we entered the town and asked for my palm-wine tapster whom I was looking for from my town when he died, but the deads asked for his name and I told him that he was called 'BAITY' before he died, but now I could not definitely know his present name as he had died. When I told them his name and said that he had died in my town, they did not say anything but stayed looking at us. When it was about five minutes that they 
were looking at us like that, one of them asked us from where did we come? I replied that we were coming from my town, then he said where. I told him that it was very far away to this town and he asked again were the people in that town alives or deads? I replied that the whole of us in that town had never died. When he heard that from me, he told us to go back to my town where there were only alives living, he said that it was forbidden for alives to come to the Deads' Town. (PWD 96)

The whole episodic work is made up of strange and unusual narration of equally strange and fantastic stories like the excerpt above. It is a direct transliteration of nonmetaphorical Yoruba speech into English without the mediation of the latter or former's grammatical or idiomatic filtration. Its publication is a symptom of what Graham Huggan has described as the anthropological exotic (Postcolonial Exotic 37).

Literary exoticism is consonant with the Western 'naming' and anthropologising of 'Africa.' It goes back to those narratives of the exotic which invented Africa (V.Y. Mudimbe, 1988) as the dark continent, as a Hegelian tabula rasa, as a primitive, dangerously fascinating foil for Europe; as a general curiosity and an object of spectacle, devoid of human presence or imagination (Hammond and Jablow, Africa that Never Was, 1970:13-48; Adam Hochschild, King Leopold's Ghost 1998: 1). It cannot be over-emphasised that this structure of feeling within the global canon harks back to, and "masks [,] the deeper question of Western representation of Africa as a continent of absolute horror, a theatre of primordial savagery, only temporarily interrupted by European colonization" (Amselle, 2003 qtd. by Pierre in Zeleza The Study of Africa Vol. 
I, 2006: 55). Such a view is inherent in a foundational Western anthropological "mode of perception and consumption" (Postcolonial Exotic 37) of African literature.

The reception of PWD emphasises an originary metropolitan anthropologising of African writing. Dylan Thomas described PWD in the London Observer (July 6, 1952) as a "“brief, thronged, grisly and bewitching story, or series of stories written in 'young English' by a West African" (Amos Tutuola 7). 'Bewitchment,' on the one hand, is a euphemism for the exotic, echoing other metropolitan critics' more direct anthropological registers in their appraisals, while 'young,' evokes a perennial idea of primitivism but goes further in connoting a minor writing in 'english' from the periphery of civilization. This only confirms the universal invincibility of a Great Tradition of writing in 'English.' It is hardly surprising that the Nigerian critical establishment, with its Diaspora at the time, was scandalised by the Western conflation of Tutola's animist images with a 'true' representation of a 'primitive' Africa frozen in time. Its outrage resulted in a controversy in the pages of West Africa, where Babasola Johnson remarks: "Palm Wine Drinkard should not have been published at all" (West Africa, April 10, 1954 cited in Amos Tutuola $31)$.

While a few Nigerian commentators were either indifferent or enthusiastic about the work, the strong distaste for its Western ideological prompts can be summarised in I. Adeagbo Akinjogbin's trenchant identification of the anthropological symbology of Tutuola's celebration in Europe upon learning that the work has been translated into French: "[m]ost English, and perhaps, Frenchmen, are pleased to believe all sorts of fantastic tales about Africa, a continent of which they are profoundly ignorant" (West 
Africa, June 15, 1954 cited in Amos Tutuola 41$)^{28}$

"The Natural Artist" (2006) Gail Ching-Liang Low's Book Historical survey of the material processes surrounding the publication of the PWD manuscript highlights Faber and Faber's bewilderment, ambivalence and excitement when confronted with a work, which "provoked acute anxiety over how to manage [its] meaning" (21). By 'meaning' Low refers to the publisher's indecision on whether to editorially market this as an anthropological or a literary work. It was decided to promote the work as literature, with the understanding that its strength lies in its anthropological value for the critical industry, the metropolitan reader and academic institutions. This market logic and decision could not have been arrived at without the originary discursive representation of Africa in the Western imaginary as a primordial, exotic and strange place, at odds with Western modernity.

Faber and Faber's "deliberate staging" ("Natural Artist" 23) of PWD as the work of a 'natural artist' imbued it with a value that resonated with the metropolitan critical establishment and lay readership. Low reports Michael Swan as being convinced that "European readers could not fail to be impressed" (qtd. in "Natural Artist" 16). He declares: “[...] Swan's London Magazine review was written with a nod towards primitivism [sic] recently made fashionable in the visual arts" (16). Comparing PWD to "other primitive literatures" one commentator embellished by insisting its charm is augmented by its "Africanness" (Calder-Marshal The Listener Nov. 13, 1952 qtd. in Amos Tutuola 10). Swan further describes PWD as the "the vision of the pagan bushman setting down the ancient sagas of his people with his own additions" (qtd in Low 16).

\footnotetext{
${ }^{28}$ See a full detail of the West Africa controversy in Bernth-Lindfors-edited Critical Perspectives on Amos Tutuola (1975: 29-44)
} 
The anthropological reception of PWD would be so important towards its canonization that Geoffrey Faber's March 15, 1951 letter "represented the manuscript's anthropological value in no uncertain terms" (ibid. 22). He wrote the anthropologist, Darryl Forde, to request an assessment of the manuscript to confirm "whether it has its roots in the common West African mind" (Lindfors Amos Tutuola 1975: 95 qtd in "Natural Artist" 22 original emphasis). Anxieties over a threat to anthropological, and thus literary, value were raised at Faber and Faber when a reader wrote to the London Magazine to question the authenticity of the author's handwriting in the facsimile page accompanying the first edition (see Holiday London Magazine Vol. 1.8, 1954: 74 qt. in "Natural Artist" 25).

The significance of PWD's prompt initial global canonisation is that, beyond traditional understandings of cultural capital and literary value, most times it is a concatenation of opportune material conditions and market forces which result in canonisation. This means that literary value is not a static synchronic category but is subject to the vicissitudes of diachronic material conditions and social relations. The example of PWD also emphasises the urgency of actual access to the means of cultural production - that is, publishing, towards the initiation of any form of canon making process. "It is obvious that (with a few possible exceptions) a work must become a material object by means of publication before it becomes a candidate for a pedagogical canon" ("Pedagogic Canons" 57)

Lindfors recounts the accidental social relations which resulted in Tutuola's manuscript ending up at the offices of Faber and Faber. The near-illiterate would-be writer started that vocation "out of boredom" (Amos Tutuola 275). In 1950 he reads the 
advertisement of a London Christian publisher's proselytising list in a local Newspaper. He then randomly sends out an unsolicited material of the most 'pagan' of stories to the most unlikely of institutions such as the "United Society for Christian Literature" (276) for its dissemination. Low recounts that he sent it to the association's Lutterworth Press directly ("Natural Artist" 21). Mary Senior, "the Assistant secretary of the African section" (21) of that body, known for encouraging African writers - particularly of religious subject matter (Amos Tutuola 94 qtd. in "Natural Artist" 21), acknowledged receipt, informs the writer that they do not publish novels, but promised to help him find a publisher.

Rather than an elaborate recounting of this much covered literary history, it is enough to remark that further aggravation of social relationships between different individuals, the comingling of attraction, repulsion and fevered interest in the manuscript led to the publication of the work in 1952 ("Natural Artist" $21 \mathrm{ff}$ ). On the heels of the series of social and economic forces, which made of Tutuola "the first Nigerian author to win international recognition and acclaim" (Amos Tutuola 276), "by 1955" (276), PWD was "available in French, Italian, German, and Serbo-Croatian translations" $(276)^{29}$.

After publication a literary work is subject to a complex of other kinds of social relations within the academy and within literary validating mechanisms, which accelerates or impedes canonization in the classroom as exemplified in Gallagher's anecdotal account of how she came to include the third generation Zimbabwean, Tsitsi Dangaremgba's, Nervous Conditions on her own syllabus ("Pedagogical Canons" $57 \mathrm{ff}$ )

\footnotetext{
${ }^{29}$ Lindfors makes a notation at the time of the publication of his critique that PWD was also available in Danish and Swedish translations.

${ }^{30}$ Mark A. Eaton ("Imaginary versus pedagogic Canons" 2001:305ff) was in turn influenced to include this work in his syllabus due to having read Gallagher essay about it.
} 
Due to a dearth of publishing resources in the Postcolony attending socio-economic erosions (Bearing Witness 2000; Voice from the Fringe: xv-xxvii), and as Gallagher notes, "[w]hen it comes to African texts, the means of production are especially decisive" (57) in the processes leading to their dissemination in the first instance. The importance of access to publication, rather than cultural capital, I will add, is the crux of Richard A. Peterson's ("Six Constraints" 1985) discussions of possible limitations of it.

Peterson identifies six such inhibitors to literary production. These are, according to him, "technology, law, industry structure, organizational structure, the market and occupational careers" (45). Together or singly, they determine if a work gets to be published in the first instance. Naturally due to his "production of culture" (46) approach he unpacks a "complex network which for the sake of simplicity can be called the publishing industry" (45) into the aforementioned six separate categories of "constraints" to publishing. For a contemporary African literature produced in a continent under postcolonial socio-economic and political siege (Osha "Continent under Siege" 1998), which is co-terminal with and complicated by a history of colonial and neo-colonial plunder and erosions (Ekeh "Colonialism and the Two Publics in Africa" 1975, Bayart Politics of the Belly 1993; Chabal and Daloz Disorder as Political Instrument 1999), only two of those six factors have immediate relevance - the market and that 'industry structure,' under which the other factors maybe subsumed. I will briefly discuss the importance of 'industry structure' to the metropolitan canonisation of contemporary African literature in relationship to the global market.

Industry structure, for my purposes, is the actual system and social relations between author and publisher that can result in access to printing technology and the 
actualisation of the literary work as a material object. Industry structure enables print capital, which - in my opinion and particularly where African literature is concerned - is more important than cultural capital towards global canon forming processes. The term print capital echoes Benedict Anderson's idea of print capitalism in Imagined Communities (1991) where he discuses the sixteenth century overseas diffusion of the European book market. Cultural capital as it is currently deployed in Book Historical or Sociological analyses exists in its 'negative' aspect only, that is, only in the realm of possibility. Its 'positive' dimension would be the actual production through the aid of analogue or digital technology as a means of 'illumination' (Benjamin "Mechanical Reproduction" in Illuminations 1968).

The term 'negative' and 'positive' are marshalled from the language of analogue reproduction photography, where film material is the 'negative' of a virtual photograph, which is finally actually re-produced through chemicalisation in the dark room. The 'negative' of cultural capital is the latent ability, schooled or un-schooled, to produce a work of art; its 'positive' is the actualisation of that latency in solid form. The physical art object - in this case the book - is materialised or illuminated in two ways. The traditional approach is followed through within a series of analogue mechanical processes from text generation, reproduction photography of the reflection copy and colour separation, transference of reflection copy unto film material, montage, colour separation, plate-making to actual presswork on the offset printing machine and finally binding. All of that, as one continuous process, is preceded of course by other pre-production editorial procedure such as the assessment of manuscripts and mark-up of galleys; and those are, 
in turn, superseded by other post-production processes - post-mortem of bound book, advertisement, promotions, reading tours and so on.

The other method of actualising print capital in a highly digitised world is, of course, digital. It takes the form of the e-book or online literary journal publication. In the e-books instance production involves the generation of text and storage of the manuscript on online servers. Such material can then be accessed through the world-wide-web as virtual text material or through portable electronic tablets such a 'kobo,' which is connected to the Internet. Sometimes there is a marriage of analogue and digital technology in print-on-demand (POD) technology such as the Expresso Book Machine, which calls up texts stored in online data banks, prints them in high machine quality and binds the result in a three-colour paperback all within minutes.

It must be noted, however, that there is a strong limitation to the canonisation of virtual forms. Physical presence has traditionally defined, and is an unexpressed condition, for the consecration of the art object - the word, object, is understood literally even if this situation might change as the future becomes more and more digitised. The situation might be changing already since short literary pieces published in online journals are admissible to some African literary competitions like the British Caine prize, which has launched writers' careers. But by and large and for the moment in discussing third generation African writing and its canonisation, reference is, of course, to the book as a physical object. If a writer has online presence it is, most of the time, distantly secondary to the business of a consistent and firm consecration. The only first serious scholarly engagement of the influence of cyber culture on African literary production is a groundbreaking study by Shola Adenekan in African Literature in the Digital Age (2012 
$\mathrm{PhD}$. Dissertation, Birmingham U). Such scholarly engagements might direct more attention, and give more weight, to the canonisation of virtual forms eventually.

The post-production stage of print capital mentioned above naturally leads me to that other important question of the market since the publisher carries out most post mortems towards the promotion, possible consecration and canonisation of the writer with a goal to the commercial success of the work. The first consideration for Geoffrey Faber in publishing PWD was financial. The inarticulacy of Tutuola's prose and his fantastic fairy tales was marketable to a Western audience. Geoffrey Faber himself confesses to a hard-nosed pragmatism as quoted by Low: "publishing is a business and like all businesses must be made to pay" ("Natural Artist" 22). The pre-production editorial policy in the handling of the manuscript of PWD was to leave it intact with its linguistic impurities. "Faber was unwilling to standardize some of the grammatical and spelling irregularities of Tutuola's script, as they would perhaps have done with other English writers" (23). In keeping with the cold arithmetic of numbers the eventual book's oddity was precisely its selling point. Faber and Faber had invested and marketed well - that is, anthropologically.

What then is the significance of the above detailed discussion of foundational metropolitan canon-forming processes which fetishsised African literature at its inception and the anthropological demands I suggest that the global canon makes of contemporary African literature towards its token consecration? It is simply that while anthropology is not an all-pervasive mode of reading African literature anymore and might be mostly a thing of the past its historical traces are so deeply etched that some new crop of writers consciously or unconsciously respond to that overwhelming trace. Within the bounds of 
authorial agency they still produce novels, which seems to be direct responses to the anthropological market requirements of the centre. This is why I refer to those works as self-anthropologising. They align their themes, narrative strategies, and ideological predilection to the residual fetishsising strictures of the global market.

Before investigating the provenance of that all-powerful market, it is necessary to probe the diverging ideological mindset of the new writer as compared to the first and second generations of African writers. This will perhaps account for the selfanthropologising discursive bias of some of these new writers and aid in contextualising their creative self-positioning.

\section{The Three Generations of African Writers}

The identity politics between coloniser and colonised, which was broached in the early part of this chapter resulted in a "crisis of Englishness" (Gikandi Maps of Englishness 1996: 9) in the one, and a corresponding "crisis of consciousness" (Onoge, 1974) in the other. African and Black aesthetics of representation naturally reflected that crisis, especially after the First World War and into the 1960s (Jameson "Periodizing the 1960s" 1984 ) and beyond. As a result "[ $[$ ] he modern African writer emerged at the dawn of the twentieth century into a framework of anti-imperialist struggle" (Adesanmi "Political Voices" in Airewele-Soyinka and Edozie ed. Reframing Contemporary Africa 2008: 259).

The reciprocal identity politics involved in African "narratives of loss" and "selfwriting" (Mbembe "Notes on the Postcolony" 2002) against imperial ideologies and representations was staged through decolonising theoretical exegesis amongst early 
twentieth century black Diaspora (Edwards "The Practice of Diaspora" 2003) ${ }^{31}$, in anticolonial continental political writings, activism and praxis and, of course, through allied anti-imperialist literary works in the continent. These responses were, as suggested above, initially articulated within the ambience of early twentieth-century "nascent black internationalism" (Edwards ibid.; Adesanmi "Redefining Paris" 2005: 959; see also Jules-Rosette Black Paris, 1998; Kesteloot Intellectual origins, 1972; Erbune and Braddock "Paris, Capital of the Black Atlantic" 2005), which encompassed radical philosophies and mutually self-reinforcing politico-cultural movements and ideologies such as Negritude, Ethiopianism or Pan-Africanism (Shepperson 1953; 1962), Harlem Renaissance (Huggins 1971) and, Negrismo and indigeneism (Jahn Neo-African Literature 1968).

On the African continent fictional narratives contesting imperial representations were mostly works by first generation Francophone and Anglophone writers in the 1950s and 1960s. A notable Anglophone example is Chinua Achebe's Things Fall Apart (1958) - a direct, deliberate ${ }^{32}$ and conscious response to two specific works in the colonial library - Joseph Conrad's Heart of Darkness (1902) and Joyce Cary's Mr. Johnson (1939). "One of the experiences that set him [Achebe] thinking very seriously about trying to capture traditional Igbo life in fiction was his reading of Joyce Cary's $M r$. Johnson, a novel that he felt provided a superficial picture of Nigeria and Nigerians" (Lindfors Early Nigerian Literature, 1982: 9). Achebe contests and rewrites the demonised image of Africa and a caricatured African subjectivity as represented in

\footnotetext{
${ }^{31}$ It is important to note that the role of Anglophone or Francophone African writers in modern emergence of the black voice in disarticulated by Paul Gilroy's criticism in The Black Atlantic (1993).

${ }^{32}$ See Chinua Achebe's polemical "An Image of Africa: Racism in Conrad's 'Heart of Darkness.' " "Massachusetts Review, 1977:18. Research in African Literatures Vol. 9:1. Special Issue on Literary Criticism, 1978: 1-15.
} 
Conrad and in Cary's novels respectively. Ngugi wa Thiongo's earlier novels count amongst other Anglophone examples.

A direct black internationalist trajectory in first generation African novelists' responses is more tractable in works by Francophone African writers of that period. While their Anglophone counterparts where contemplative, Francophone African literary works, both poetry and the novel, were combative in their self-narration and their contestations of imperial and colonial ideologies. This can be ascribed to an ironic internal contradiction in French colonial policy which culturally assimilated 'natives' in its diverse colonies as 'black French people,' only to deny them 'recognition' as migrants in the metropolis. According to Louis J. Paranscandola "[b]oth [French colonial] systems of assimilation and association [...], despite their seemingly lofty intentions, were premised on one tenet: the innate superiority of the Europeans" ("Dilemma of Identity" in Comparative Literature Studies Vol. 46.2. 2009: 360).

The result was an urgent crisis of consciousness in, and a rejection of racial interpellation by, colonised African and Caribbean émigrés, politicians, cultural elites and students in the metropolis of Paris within the aforementioned cultural, philosophical and ideological movements. Initially a student from Martinique circulating amongst the migrant Parisian left, Rene Maran gives an aesthetic response to that identity politics with the 'fighting book,' Batouala (1921), which won the prestigious Prix Goncourt prize. The novel's "preface $[\ldots]$ became the precursor of a protest tradition that was to bind subsequent generations of francophone African novelists to political engagements rooted in ideologies of decolonization" ("Political Voices" 259). Maran exposes the 
Enlightenment project as "an elaborate farce" (ibid.). ${ }^{33}$ Importantly, the novel's preface "created a sense of urgency around acts of political enunciation that necessitated an extratextual recourse to the preface in the tradition of the political novel in Francophone Africa" (ibid).

The oeuvre of the first generation Cameroon writer, Alexandre Biyidi Awala, otherwise known as Mongo Beti, questions colonial assumptions and self-assurance (Mission to Kala 1964), the subordination of the African based on the deceptions ${ }^{34}$ and cultural arrogance of Christianity in Africa (The Poor Christ of Bomba 1954) ${ }^{35}$."The most significant aspect of Mongo Beti's strategy remains his urgent need to produce a literature where blacks are no longer an object of reflection, but a subject of selfreflection" (Mbaifu "Mongo Beti and the 'Curse' of Ham" 2002:13). That quote might as well be referring to the ideological intent of one of Beti's contemporaries, Ferdinand Oyono, who in the novel, Houseboy (1956) makes his self-reflexive protagonist, Toundi, ask the all-important self-searching question, "What are we Blackmen who are called French?," (13) as he lay dying. "This seemingly simple statement [...] actually was one of profound complexity pointing as it does to the dilemma of colonial identity" ("Dilemma of Identity" 360). The ideological preoccupation of other first generation

\footnotetext{
${ }^{33}$ Adesanmi directs us to the combativeness of Maran by quoting from Batouala's preface: "Civilization, civilization, pride of Europeans and their burying-ground for innocence; Rabindranath Tagore, the Hindu Poet, one day in Tokyo, said what you were! You build your kingdom on corpses. Whatever you may want, whatever you may do, you act with deceit. At your sight, gushing tears and screaming pain. You are the might which exceeds right. You aren't a torch but an inferno. Everything you touch, you consume. (Batouala 16-17 qtd. in Adesanmi "Political Voices" 2008: 259)

${ }^{34}$ One of those misrepresentations is the justification of slavery and colonialism based on the mistranslated story of a 'cursed' Ham in the Bible, who is then made to symbolise black people in colonial discourse. See a full discussion of this in "Mongo Beti and the "Curse' of Ham: Myth and History in Africa" (Research in African Literature Vol. 33.2 (2002): 9-33).

${ }^{35}$ Of this work, which first edition was banned in Cameroon at the instance of the Catholic mission there in the person of Archbishop Graffin of Younde, Mbaifu and Mitch quote: " 'Several priests, after having read some pages of the novel, closed it, tore it, or burned it, because they were shocked and scandalized to see their stock image thus deformed and ridiculed' (Laverdière "Les missionaires et le christianisme dans la littérature camerounaise." U of Paris Doctoral Thesis. qtd. in Mabifu 2002: 15)
} 
Francophone and Anglophone African writers follow pretty much the same trajectory, coalescing in the "writing back" paradigm made famous in postcolonial studies by Bill Ashcroft et al in The Empire Writes Back (1989).

In the forgoing I have demonstrated that modernity's discursive superstructure resulted in black counter-modern narratives amongst the first generation of African writers in the sense understood in Latin Americanist discourse (Mabel Morafia et al Coloniality at Large 2008), especially as expressed in Enrique Dussel's idea of a "transmodernity." "[M]odernity's recent impact on the planet's multiple cultures $[\ldots]$ produced a varied 'reply' by all of them to the modern 'challenge.' Renewed, they are now erupting on a cultural horizon 'beyond' modernity. I call the reality of that fertile multicultural moment 'trans'-modernity ("World Systems," 2002: 221). Needless to say, the 'writing back' mode in African literature forms a strand in the inter-textual globalisation processes elaborated upon by Michael Valdez Moses in The Novel and the Globalisation of Culture (1995). Beyond the 1960s into the 1970s that writing back mode was not sustained in the second generation. The disillusion of eventual independence set in and the second generation, along with the first, became introspective and focused their ire on the postcolonial state. Into the 1980s the prevailing mood of disillusion was inherited by the third generation, to whom I will now turn my attention.

"Third generation African writing" (Adesanmi and Dunton, in English in Africa 2005:7-19) is a critical rubric describing a continent-wide ${ }^{36}$ literature produced after

\footnotetext{
${ }^{36}$ Continent here refers to sub-Saharan black Africa mostly, although the impact of colonialism on Arab North Africa, such as Algeria, also produced literatures in European languages. Albert Gerard (1986) discusses the impact of colonialism on the Maghreb. See also Ziad Bentahar's essay on the critical separation of the Mahgreb and Black Africa within African Studies in "Continental Drift: The Disjunction of North and Sub-Saharan Africa" in Research in African Literatures Vol. 42. 1, 2011 : (1-13)
} 
independence, which began in 1957 with Ghana ${ }^{37}$, excepting for South Africa ${ }^{38}$ and a few countries of the Maghreb, which gained modern sovereignty at later dates. African writers who belong to this category are mostly born around or after 1960 , the signal date of continuous decolonisation on the continent.

One of the distinguishing characteristics of writers of the third generation, which has come to receive general critical acceptance in Africanist discourse and by the writers themselves, is their absence from the colonial scene. Pius Adesanmi theorises this group as "non-ocular agents" as opposed to "ocular agents" ("Africa's New Intellectuals" in Toyin Falola Dark Webs, 2005: 270) of the colonial event. Non-ocular agents, he elaborates, are "those who never witnessed the events [i.e. colonialism] in question but who were born into the social, cultural, economic, political, and spiritual processes and contexts that have been massively overdetermined by the said historical event" (270).

The overwhelming impact of colonialism and the ideologies of decolonisation and cultural nationalism on the textual regimes of first and some second generation writers, and their very stark absence in the ideological bent, narrative strategies and thematic preoccupations of writers of the third generation has necessitated these writers being variously described as "children of the postcolony" (ibid. 275) - in Francophone Africa by Abdurahman Waberi ${ }^{39}$. They are the "uhuru" (read freedom), "post-trauma" and "beur" generations in East and South Africa, and in the Maghreb, respectively. ${ }^{40}$ In

\footnotetext{
${ }^{37}$ According to Paul Tiyambe Zeleza in "African Studies and Universities" (2009), "Ghana was not the first African country to gain independence from colonial rule in the twentieth century- that honor belongs to Libya, which achieved independence in December 1951, or perhaps Egypt, which became self-governing in 1922" (110). Nevertheless, my geographical focus is this study is Sub-Saharan Africa.

${ }^{38}$ South Africa is unique in being the only European colony that got its independence at the turn of the $20^{\text {th }}$ Century, in 1994.

${ }^{39}$ Waberi is an important and a very relevant writer to third generation francophone African literature.

${ }^{40}$ See "Of Generations and Limits," online interview with Pius Adesanmi by Nnorom Azuonye at $<$ http://www.sentinelpoetry.org.uk/0607/adesanmi interview.htm> 04/09/07.
} 
Nigeria they are simply the 'third generation.' Despite what appears to be a clear-cut delineation of literary generations in African literature, there are still some uncertainties in the matter of periodisation.

"When is a generation?" This is a problematic question raised by the editors of English in Africa in a 2005 special issue of that journal on third generation Nigerian writing. For the first time full scholarly attention was directed at this corpus of burgeoning Nigerian literature and it became necessary to define its boundaries. In the same journal, and talking in the context of poetry, Harry Garuba ("The Unbearable Lightness of Being" ibid. 51ff) noted the contradictions, indeterminacies and overlaps which - even amongst writers with the same mental and social formation, or thematic and stylistic bent - threaten an effort to create clear-cut boundaries, schools or 'generations' for a Nigerian (Anglophone) literature that is relatively young and could probably develop in unimagined directions in the future. Adesanmi, in the same journal and as mentioned earlier, approaches the problematic of periodising new Nigeriana by emphasising writers' "location in relation to the temporal frame of the colonial event" (op.cit. 275). However amongst other considerations, he makes a note about "factors such as age bracket" (ibid).

It is pertinent to draw attention to Adesanmi's invocation of 'age' above because Garuba also points to its implication in the word, 'generation.' "[T]he term generation is still an ambiguous, unstable one because in some instances it appears to refer to age and in others to the time of first appearance of the poet in the public domain" (52). The insinuation of age or 'age-ism' in the term 'generation' rather than a non-gerontologic 'school,' points to traces of that gerontocracy especially typical of African cultures. This, 
as I have noted elsewhere in a review ${ }^{41}$ of English in Africa, is reflected in formal and informal discussions which unconsciously lump writers into a particular 'generation' due more to their age rather than the initial moment of their scribal praxis. In such ageinflected generational discrepancy, we might find Abubakar Gimba (1952- ), Zaynab Alkali (1950- ), Tess Onwueme (1955- ), Niyi Osundare (1947- ), lumped together with Femi Osofisan (1946- ), Bode Sowande (1948- ), Kole Omotosho (1943- ), Odia Ofeimun (1950-) as second Nigerian generation writers. ${ }^{42}$

The reality is that in spite, and ironically because, of the now accepted temporal dividing line marked off by colonialism, the first group of writers above are actually third generation - if we go by when they began publishing, that is in the $1980 \mathrm{~s}$ - and even though they were born much earlier than the core members of the third generation. Harry Garuba (1958), as a poet whose first collection was issued in 1982, is more second generation than Niyi Osundare who published his first poetry collection in 1983. In such a reckoning Niyi Osundare, and the aforementioned writers, except Femi Osofisan, Odia ofeimun, Bode Sowande, belong in the third generation. The 1980s is the period when

\footnotetext{
${ }^{41}$ This was a review I wrote while I edited the sentinel online poetry journal. See issue 47 of the journal at $<$ http://www.sentinelpoetry.org.uk/1006/englishinafrica.htm>. Assessed 20 June, 2012. In that review I remarked that: "Garuba eloquently articulates the contradictions involved in the hurried declaration of a 'generation' within a still growing body of work or in the announcement of a school; nevertheless since the colonial event and its aftermath is the one single most important existential conditioning of the modern African psyche, there is a sense in which such contradictions are actually a symptom of the postcolonial moment. In effect it could be useful to subsume the problematic of naming - as far as the third generation goes - under the rubric of a postcolonial 'skool' as opposed to a 'school', the differentiating consonant in 'skool' exemplifying and emphasizing the burden of those contradictions and the "colonial hangover" inherent in the politics and styles of those writing after colonialism, whether they belong to a third or fourth generation ad infinitum.

${ }^{42}$ The most extreme example of this gerontological categorisation can be found in Obi Nwakanma's ("Narrative of the Nation" 2008: 4) suggestion of the first generation of Nigerian writing to begin with Oluadah Equiano, Nnamdi Aizikwe and so on. He even suggests a "fourth" (4) generation against the now accepted rubric of three generation, of which the first two is demarcated by their nearness to colonialism, which the third did not witness. Nowhere does he proffer a methodological rationale for this categorisations.
} 
third generation writers ${ }^{43}$ came to literary consciousness and began publishing according to the historical surveys in English in Africa (2005) by Remi Raji in "Ibadan and the Memory of a Generation" (21ff) and Maik Nwosu's "Children of the Anthill" (37ff). The time of first publication should be an important factor in placing works within or without generational boundaries - especially within the grey areas of third generation writing.

In a more global context Frederic Jameson ("Periodizing the 1960s" 1984) has noted the difficulties of an organic approach to a periodising of history due to the constructedness of such a monolithic concept. While he considers the subject a necessity, his intention is not a "theoretical justification of periodization in the writing of history [... nor is it a conflation of] cultural periodization [... with] some massive kinship and homogeneity or identity within a given period" (178). Rather, Jameson, like Garuba, agrees that there are overarching paradigms - the "historically dominant or hegemonic" (ibid.) - against which one can begin to frame contradictions, continuities or departures. In the general case of the global South and in the ambience of the 1960s, Jameson indicates the prevalence of decolonization, and by extension, colonialism, as broad paradigms for the emergence of " 'Third World' subjectivities and aesthetics" (180ff).

As I noted in my aforementioned review of English in Africa it might be useful to "subsume the problematic of naming - as far as the third generation goes - under the rubric of a postcolonial 'skool' as opposed to a 'school,' the differentiating consonant, ["k"], in 'skool' exemplifying and emphasising the burden of those contradictions and the

\footnotetext{
${ }^{43}$ I was part of the literary activites around the university of Ibadan poetry club in the 1980s, with Harry Garuba, Remi Raji, Nduka Otiono, Chiedu Ezeanaha, Sanya Osha, Emma Oga, Onookome Okome, and many others are its core members.
} 
'colonial hangover' inherent in the politics and styles of those writing after colonialism"44 'School' is inapplicable in a Nigeriana that is still an open-ended and growing canon and, due, of course, to insufficient or settled stylistic, thematic, or dispositional generational uniformity.

"Born after 1960, the writers among this new generation of African intellectuals published their first books in the mid-1980s and by the 1990s some of them had established continental and international recognition" (op.cit. Adesanmi in Falola Dark Webs 2005: 276). Nevertheless, the internationalisation of the third generation is subject to the canonical restrictions implicit in cultural relationships between the centre and the periphery based on a historical "politics of Otherness" (Jameson op.cit. 186). That politics is now being played out within the field of cultural production at the site of the global book market. A review of the development of the African section of that market will reveal its foundational colonial hierarchies.

\footnotetext{
44 see review of English in Africa in sentinel Online poetry Journal at $<$ http://www.sentinelpoetry.org.uk/1006/englishinafrica.htm>
} 


\section{Chapter Two}

\section{The Global Market in the Local Margin}

The foregoing chapters map the historical trajectory and politics of the tokenist emergence of African writing as world literature within the global canon. The significance of Western market imperatives to literary value in African literature has been referenced above in the example of Faber and Faber's publication of PWD. Nevertheless, the development of the African book market and its relationship to Western markets requires a little elaboration before focusing on the global market's delimiting of contemporary discursive formations in African literary production generally and Nigerian writing particularly.

Africa's cultural, socio-political and economic insertion into Western markets, in this case the book market, was accompanied by the acculturating technologies of Christianity and printing - a phenomenon I will refer to as print imperialism. ${ }^{45} \mathrm{I}$ consider Christianity a 'technology' because it was a symbolic tool ${ }^{46}$ within a capitalist machine (Deleuz and Guattari Anti-Oedipus 2000), of which colonialism was a systemic, centralising administrative engine. It was ideologically designed to set up a powerful cultural form of capitalism - "print-capitalism" (Anderson 1991: 43), while enabling another kind - the monetary and mercantile. ${ }^{47}$ Benedict Anderson encapsulates print

\footnotetext{
${ }^{45}$ This echoes "media imperialism" in media studies discourse. See Chapter 2 of John Tomlinson's Cultural Imperialism: A Critical Introduction (1991) for detailed discussion of media imperialism. Amanda Griscom (1996) deploys a similar expression, 'Textual Imperialism,' to discuss Europe's ability to impose its ideologies on the rest of the world through printed matter after Guttenberg. For details see: http://www.cyberartsweb.org/cpace/infotech/asg/ag12.html

${ }^{46}$ The Christian Missionary Society's (CMS) records at the University of Birmingham's special collection unit show that the English clergy doubled as educators - teachers and principals for primary and 'Grammar' schools.

${ }^{47}$ It is documented that the Church Missionary Society, CMS clearly had working relationships with the Royal Niger Company, the unofficial commercial representatives of the colonial government. Church and
} 
capitalism as the phenomenon at work when printing technology, new at the time, exacerbated the capitalist boom in Europe around the 1500 s and 1600 s due to the introduction of a new commodity - the book (37ff). After Gutenberg's invention of the printing press in the late $1400 \mathrm{~s}$, there were $20,000,000$ books in print according to Anderson. Quoting Febvre and Martin, he notes that about a century later between 1500 and 1600 the number had risen to between $150,000,000$ and $200,000,000$ (1991: 37). As a result of this rapid growth in the book trade the European publisher expanded all over that continent and was actively canvassing for markets elsewhere (37-38). Understandably over-saturation of the European market meant that the logic of capital would naturally insist on expanding into European colonies in the semi-periphery and peripheries.

The twentieth century penetration and opening up of African markets by transnational European book publishers was at once a pedagogic, an economic as well as a cultural annexation and the continuation of imperial control. Caroline Davis ("Politics of Postcolonial publishing" 2005) claims that: "Oxford University Press [OUP] was one of several British companies that consolidated publishing empires in the postcolonial period" (228 my emphasis). Other British publishers, all of whom are still active on the continent as indigenous, semi-autonomous entities, are "Heinemann, Evans, Macmillan and Longman" (230). The same colonial historical conjuncture that resulted in the discursive formation of a global school culture also produced a transnational publishing culture centred in the metropolis, for which the local and 'peripheral' subsidiaries were

State collaborated to enable the accumulation of Capital. The Introduction to The Church Missionary Society Archive (Adam Mathew Publications, 1997) states that "the opening up of Christian mission (sic) originated in the desire of British merchants to extend their trade on the West Africa (sic) coast. Following the discovery of the source of the Niger in 1830[,] Thomas Buxton combined commercial arguments with his zeal against slavery and urged the government to undertake expeditions into the interior" (11). 
originally only textbook sales outlets. This was as a result of a large African textbook market created initially at the primary and secondary school levels by a "vastly expanding" (Ibironke 2008: 9) colonial school culture ("Politics of Postcolonial Publishing" 229; see also Currey "Establishment of African Literature" 2003: 578-579; Clarke "Forty Years of Publishing" 2003: 163) and later at the tertiary and University levels. In a speech delivered in London in September 1969, Allan Hill ("African Writers Series" 1971), executive at Heinemann Publishers, remarks that "the English-speaking countries then, on the verge of independence, were a good market for British books - but almost all of the books bought were school textbooks" (18).

The diffusion of British book markets into Africa was so programmatic that between the 1940s and 1960s there was already an overwhelming presence of these multinationals in Africa. British publishing in the colonies was so well entrenched considering Davis' detailing of just one example of their extended African networks - the aforementioned OUP:

New [sales] offices were established by OUP in South Africa (reopened 1946), Nigeria (1949), East Africa (1954), and the Gold Coast (1955). As African nations achieved political independence in the early 1960s, OUP sales offices throughout Africa were converted to publishing branches. In 1963 the Nigeria branch [...] and East Africa [publishing] branch were opened, followed in successive years by branches in Lusaka (1964), Addis Ababa (1965), and Accra (1966). (228)

Although other British houses with literary interests were equally very active - all initially as sales outlets for colonial educational material - it was the singular herculean 
effort of Heinemann's literary experiment which perfected the cultural annexation of the periphery through a continentally coordinated sourcing, promotion, cross-translation ("African Writers Series" 20) and incorporation of Literature in English into English Literature. It ventured into, and expanded its operation through, literary publishing in the form of the 'African Writers Series' "initiated by Van Milne, then Overseas Director" (19). The purpose was to expand its educational list into the University curriculum, and thus replace "eminent British writers from Jane Austen onwards who had hitherto dominated the lists of prescribed texts" (19; see also "Forty Years of Publishing" 164) with literature written by African authors. Chinua Achebe, whose Things Fall Apart was published "in 1958 in hardback under the general market imprint of William Heinemann in hardcover" ("Establishment of African Literature" 575) "generously agreed to be General Editor"48 ("African Writers Series" 19) of the imprint, with his own book being reissued as the first in this paperback series in 1962.

In Davis's words "[t]here was [...] considerable competition among [...] British publishers in Africa to establish literary lists and to obtain manuscripts from novelists, poets, and dramatists in the newly independent states" (232). However, Heinemann emerged as the "market leader in this field" (234). Until its demise forty years after initiation "[t]he African Writers Series [became] established as the canonical series of African literature" ("Forty Years of Publishing" 165). Becky Clarke ascribed this to Heinemann's strategic global self-positioning on the continent compared to its competition. Apart from its simultaneous presence in "Ibadan, Nairobi, Malawi, and South Africa" (164), it had "a host of agents strategically placed demographically"

\footnotetext{
${ }^{48}$ There is a consensus in all accounts of the history of the African Writers Series about the editorial role Achebe played, although James Currey describes him in his (Currey's) essay as "Editorial Adviser." ("Chinua Achebe and African Writers Series" 2003: 576). That was probably Achebe's initial 'office.'
} 
(164).

Although Oxford University Press initiated the Three Crown Series in the same year (1962) as Heinemann, under which imprint the early plays of Wole Soyinka and J.P. Clark were issued, that imprint however only lasted till 1972 ("Politics of Postcolonial Publishing" 233ff). Other literary series by competing British houses all over Africa and Nigeria were 'Forum' and 'Drumbeat' by Longman, Pacesetters - Macmillan's popular fiction imprint for the Nigerian market - and "East Africa Publishing House's Modern African Library, which published original African literature for the Kenyan market" (234). The territorialisation of capital activity and encircling of the African market by British global publishing structure would be finalised with the onset of University presses.

According to Kwasi Darko-Ampem (University Press Publishing” 2005), in modern Sub-Saharan Africa "there were [...] no university presses until the [colonial] University of Ibadan formed the nucleus of one in 1952" (90). It became fully operational in 1955 , while the University of Ghana Press was founded in 1962. Other University presses in Africa emerged between 1957 and 1993 (90 ff). ${ }^{49}$ Since the University curriculum in Africa was entirely British in the post-war period, African school culture became a colonial industry supplied by the "transnational corporation" (Miyoshi "Borderless World?" in Global/Local Wilson and Dissayanake 1996: 97). Davis remarks that "[t]he end of formal colonization in Africa gave British publishing companies the opportunity to become more, not less, deeply entrenched in the cultural life of the

\footnotetext{
49 see also Pius Adesanmi's "Third Generation African Writing and Contemporary Theorising" (in Zeleza The study of Africa 2006: 104) where he discusses the rise of the colonial universities in relation to how they produced the first generation of African literary critics who were then weaned on Eurocentric theories of literature unsuitable for their objects - African literature.
} 
continent" ("Politics of Postcolonial Publishing" 228).

Despite intimations of cultural nationalism amongst local publishing staff and subsidiaries, commentators, critics, a nascent educated elite and educators, and the general public, the logic of capital is that efforts at curricula revision towards local content, control and dissemination was still subject to the nascent market imperatives of the centre. Davis reports that "[a]n indication of growing unrest about British and indigenous publishers in East and West Africa was the 'Publishing in Africa in the Seventies' conference at the University of Ife in Nigeria from 16 - 20 December 1973" (231). The public, private and industry discussions engendered reflected the mood of that time and the cultural politics surrounding British publishing in Africa.

At this juncture the ideological aspects of print capitalism ought to be foregrounded if only because of its originary overwhelming impact on Africa's cultural economy and its univocal dictation of what constitutes literary value, form, style genre, and canon in African literary production. Although the main focus here is the African 'literary,' as distinct from, educational market, that market is continuous with the educational without distinction, such that they should be viewed as a unit of modern African culture (see Dasylva "Culture Education" 2006) as understood here. With reference to OUP Davis says, "editors attempted to satisfy both cultural and economic demands by aiming texts at the educational market" (235). This is why I have been suggesting that print capitalism structured African pedagogy and educational material with its Western subject forming impulses - at all levels and hence had a great originary influence on local and global canon formation. Charles Larson, as expatriate witness, attests to the colonial nature of Nigeria's curriculum at the secondary and tertiary levels. 
"As a teacher at a boy's secondary school in eastern Nigeria, I at first followed a syllabus (set by the new government in Lagos) devoted only to England's great men of letters: Shakespeare, Hardy, Milton, Bunyan - all the obvious authors ("New Writers; New Readers" 81). An example of pedagogical and curricular control at the very formative primary school level is worth quoting at some length here:

West and East African examination councils were managed by expatriates who determined the syllabi and continued to recommend British and French school books. Primary syllabi were drawn up by expatriate-managed ministries of education, and textbooks were written by expatriate teachers. In addition, there were large imports from Europe of professional and children's books. ("Politics of Postcolonial Publishing" 229)

With the scenario in the examples above, it is clear that there was a Western definition of the literary and pedagogical canon despite local efforts at decolonising the African canon. That was why "[n]ewly independent countries in Africa in the late 1950's whose curricula were fashioned on European models and tradition wanted to replace European Educational literature with literature about Africans written by Africans" ("Forty Years of Publishing" 164).

Davis gives a summary of those cultural nationalist agitations with references to views expressed in papers delivered at the aforementioned conference on African publishing.

“G. O. Onibonoje proclaimed, 'The [sic] form of cultural revolution we demand must ensure that publishing in Africa is by Africans to disseminate and inculcate African culture and heritage and make the voice of Africa heard, clear and loud" 
[... and] Joseph Okpaku's paper criticized the foreign domination of the textbook publishing industry as a highly effective means of 'preventing the political and social education of the African people' (231).

Predictably in that prevailing atmosphere of local agitation for socio-cultural decolonisation, British publishers encouraged and seemed to foster cultural self-assertion in African writers and, even in the case of Heinemann, "a special feature was made of political books" ("African Writers Series" 19).

Nevertheless the ideological and imperial dictates initiated at the colonial moment subverted expatriate corporate political will and represented ironies and contradictions of local execution. Despite their efforts to encourage local cultural nationalism, British publishers inevitably expanded their domination over and control of the book market. And while appearing to contest historical misrepresentations, African authors, in order "[t]o 'write back' and affirm their dignity and identity beside the colonizer, $[\ldots]$ had to write in a language that would be understood in the metropolitan centre" (Barber "Time, Space and Writing" 200) - English; hence the half-literate exertions of Tutuola (PWD). That perennial language question - because of which Obi Wali views 'African literature in English' as a bastard nomenclature - still cannot be resolved. Moreover African writers are "hybrid products of Africa's oral lores and the western academic/literary tradition" ("Contemporary Theorising" 104). They are as much indebted to African oral forms as to the influence of Western textual/stylistic regimes. This is why the ideological and discursive space of contemporary African literature is still invariably shaped, in spite of itself, from the metropolis. Salah D. Hassan has duly noted a remarkable irony - the intertextuality of Achebe's Things Fall Apart with "the tradition of a hegemonic 
[Western] high modernism” (“Canon after Postcolonialism” 298).

The cultural colonialism inaugurated during, and intensified at the end, of political colonialism is captured in Davis' recalling of Peter Sutcliffe's comment: “" a]s the Old Empire dissolved, the Overseas Education Department set out to build a new one' " (Sutcliffe 1978: 266 in Davis 228). While highlighting the centrality of the European market regime to the colonial African book trade, and the internationalisation of African literature, Clarke captures its structuring ideological operations: "[w]hen Heinemann, alongside other publishing companies, came to Africa, it was largely, if inadvertently, to fulfil a colonial mission" ("Forty Years of Publishing" 163). Despite British publishers' consciousness of the colonial nature of their enterprise and "the importance of conveying a positive image of their publishing program in Africa [...]" ("Politics of Postcolonial Publishing" 231), that program was, inevitably, the result of, and intrinsic, to "colonial capitalism" (Culture and Imperialism 167). As it is typical with the nature of colonial expansion, "[t]he British Empire presented an open market for British publishers. The market was secured by the imposition of the British system of education throughout the colonies" ("Forty Years of Publishing Clarke" 163). The assurance of British dominance of the African market was particularly important at a point when empire was gravitating towards the USA as the new post-War superpower:

It was a highly protected market, for the 1842 and 1911 Copyright Acts applied throughout the colonies, ensuring British publishers a monopoly on their titles. British trade to former colonies was protected by means of the British Commonwealth Market Agreement of 1947, which gave British publishers a privileged position over American publishers in the sale of books to this 
territory. (163; see also Davis 234)

While the idea of capitalist activity is central to the African book market at its formation, an added imperial sense in my conception of print capitalism is that of its opening up of Africa to imperial ideologies through the initial importation of printing technology ${ }^{50}$ by missionaries.

In "Carefully Concealed Connections" (2005) Valerie Holman credits Winston Churchill as claiming: " '[b]ooks,' [...] 'offer the means whereby civilization may be carried triumphantly forward" "(1). That civilisational transference is impossible without the ideology that books - say the Bible, for example, or Western literature and discourses - disseminate. Amanda Griscom (Trends of Anarchy and Hierarchy) ${ }^{51}$ has noted that "[t]he printing press gave Western civilization the means to limitlessly duplicate particular ideas in a particular, standardized text, to extend its ideological mantle over the rest of the world." 52 Such ideologies, for example Christian pedagogy or Eurocentric accounts of African history ${ }^{53}$, were important in order to arrest and re-orient the mental life-world of the colonised.

The significance of the brief overview of the development of a transnational African book market above is that the Western publisher has always inevitably been

${ }^{50}$ See also J.F. Ade-Ajayi's The Christian Missions in Nigeria 1841-1891: The Making of New Elite (1965: 16-17). There he spells out the goals and program of Buxton's Society for the Extinction of the Slave Trade and for the Civilization of Africa: trade and printing are prominent on this list in the background of evangelism.

${ }^{51}$ See chapter two of Trends of Anarchy and Hierarchy: Comparing the Cultural Repercussions of Print and Digital Media at <http://www.cyberartsweb.org/cpace/infotech/asg/contents.html>. Assessed Sept 16, 2010.

${ }^{52}$ See Elizabeth Eisenstein's discussion of the impact of print on the cultures of Europe in "Defining the Initial Shift: Some Elements of Print Culture" (in The Book History Reader David Finkelstein and Alistair McCleery eds. 2000: 151-173).

${ }^{53}$ An example are those foreign written history school books such as that by Michael Crowther which teaches that 'Mungo Park' discovered the river Niger, which has flowed in Nigeria from time immemorial. There is also that indoctrination of African children in French colonial schools, that they are the descendants of the Gauls (the French). This idea is encapsulated in the refrain often chanted mechanically in the French colonial classroom: "Our ancestors, the Gauls." 
instrumental to African literary production's global valuation, dissemination and consumption since the inception of modern African writing. Gallagher says, for example, of Heinemann's foundational role: "[b]y virtue of its size and influence, Heinemann [was] the great African canon maker" ("Pedagogical Cannons" 57). This view coincides with that of Becky Clarke, Allan Hill, James Currey, Caroline Davis, Camille Lizarribar Buxo, Olabode Ibironke, Salah D. Hassan, and other critics of the global canon.

The Western domination of African cultural economy was complete with the harnessing of local school culture, its pedagogies, modes of literary interpretation and critical parameters by the global, to which it is infinitely yoked and subordinated. In discussing the shortfalls of applying old Western critical models to third generation writing, Adesanmi recalls the foundational hermeneutical struggle between local and global school cultures. "The stage was [...] set in the 1960s-1970s for a series of continuous confrontations between an emergent African critical establishment and an active Euro-Africanist establishment over critical standards, modalities of institutionalisation and canonisation of African literatures" ("Contemporary Theorising" 104).

Western publishing in dialogue with discursive formations within metropolitan critical, academic, interpretive, literary and literary-administrative, and institutional praxis is adroit in mapping and remapping critical, epistemological and hermeneutic trajectories for African education, pedagogy and, knowledge and cultural production. 'Education,' as laudable or innocuous a didactic category as it might seem, is itself a 'market' in any capitalist system. This is apparently why some critics of the postcolonial deploy the language of business, high commerce and technology to describe 
contemporary Western education theory, praxis and function. The capitalist automation of the Western academy is easily captured in Gayatri Spivak's reference to Western pedagogy as a machine in Outside in the Teaching Machine (1993) and, in such expressions as 'critical industry,' 'alterity industry,' 'knowledge economy,' and so on.

The monetising of African school culture is exemplified in the 'product branding' phases of African literature and pedagogy. For example, the 1960s and 1970s coincided with what was constructed by global (capitalist) school culture as 'Commonwealth Studies,' in an era aptly described by Ibironke as the 'Commonwealth period of African literature" (African Writers and Heinemann 20). With gradual mutations in the geopolitics of global power, the eventual decline of the three worlds system (Dirlik et al History After the Three World System 2000), and the final ascendancy of America over Britain as lone superpower, Commonwealth Studies, in turn, became 'Postcolonial Studies' in the 1980s. Those pedagogic categories are epistemological, as well as being capitalist 'brands;' they are subtended by a market dynamic that transcends the imparting or production of knowledge just for its own sake. This is why Buxo suggests that: "African writing, like other so-called Postcolonial literature, is a category invented by the [capitalist] west for the west [sic]" (Development of African Literature 1). Knowledge and cultural production, acquisition, and dissemination is not an abstract, elevated practice, above the 'pettiness of money' but an economic activity across the board from the primary to the university level, at which point the figure of the educator is sustained as that of a 'businessman,' and that of the educated as 'client.' In between these two figures are of course, the conduits for the transmission of education - the publisher, the bookseller, the library, the government, school boards and so on. 
The transition from, or mutation of, Commonwealth Studies into Postcolonial Studies followed the publication of Edward Said's Orientalism in 1978. The appearance of The Empire Writes Back (1988) affirmed the paradigm shift and confirmed postcolonial studies as a new area in which Western critics and their migrant colleagues from the global South 'do business.' One needs to take note that Edward Said himself is one such migrant intellectual. Due to the discursive operations of capital and power the migrant scholar based in the metropolis and originally from the former colonies such as India, Africa, the Caribbean and Latin America, has become a native informant, reacting to the caprice of a wily capitalist system, for which the periphery and its intellectual and cultural resources is simply raw material. In tracing the growth of postcolonial studies in the West, Graham Huggan's observations of the development of the discipline "suggests that the emergent postcolonial critical and theoretical industry might be seen not altogether unreasonably as having taken over where the booming trade in 'explanatory' accounts of postmodernism, peaking in the late 1980s, had left off' (Postcolonial Exotic 225 my emphasis).

Paul Tiyambe Zeleza's extensive historical interests in the nature, scope and function of African Studies, with its literatures, particularly within the American Academe and within a general contemporary Western epistemological and hermeneutical tradition, has identified it as an 'Area Studies quota' (The Study of Africa Vol. 1 \& 2, 2006, 2007; "Challenges of Epistemic and Institutional Decolonization" 2009). African Studies is usually interpellated by the center as a sub-category of knowledge and cultural production and rendered muted and supine under the panopticist review of power/knowledge strategies. Such Strategies invariably emanate from desire for profit in 
literal and symbolic ways, and of course, for control.

Importantly the capital acquisition and territorial expansion which motivated Empire and sustained Euro-American publishing would not have been possible without the orchestrated and single-minded cultural programs initiated throughout Africa by British and French colonial and postcolonial, official and unofficial Western cultural bodies. The British Council and Alliance Française are two important examples. Their cultural agenda - cultural-linguistic, nationalist/imperialist and the creation of markets are supplemented by a Western private and corporate patronage system's literal and symbolic "prizing of otherness" (Postcolonial Exotic 225; 105ff). James F. English insists that "the investment of foreign symbolic capital in emergent symbolic markets [...is] a means of sustaining less overtly and directly the old patterns of imperial control over symbolic economies and hence over cultural practice itself" (Economy of Prestige, 2005: 298).

In the above respect such contemporary prizes are of urgent relevance in the cultural relationship between the North and South. Some of these awards are the Caine Prize for African Writing and the much more recent Penguin Prize for African Writing, both of which specifically targets third generation African writing. They are important because of their perpetuation of colonial cultural relationships and their continuing incorporation of Literature in 'english' into English Literature in the twenty first century. From the foregoing clearly the market, of which prizes are a tuning fork, plays an important role in literary valuation. Significant and apparent as the accumulation of capital is to the very idea of literary value, most contemporary critiques of canon 
formation mostly elide the market as a factor and couch discussions usually in terms of the equally important binary of power and ideology only.

However, metropolitan publishing establishment understands the significance of book sales as a facilitator and counter-weight to, or modifier of, ideology and power. This is reflected in the already mentioned example of Geoffrey Faber's ascription of value to Amos Tutuola's initially bewildering but exotic and thus profitable manuscript. Stec, in commenting on the self-interest of publishers, notes that "[c]anons ultimately have as much to do with profit as with "artistic worth"' ("Publishing and Canonicity" 140). To that one might add that sometimes profit might obliterate, modify or decide what 'artistic worth' actually is, as in the case of some self-anthropologising third generation novels. It can be argued that contemporary African writers' acquired artistic disposition as occasioned by prevailing metropolitan market forces shape their collective ideological hand, even if those forces are not the only factor at play. Most, if not all, globally successful contemporary third generation literary production are in the prose fiction form and written in the narrative ambience of the "anthropological exotic" (Postcolonial Exotic 32). That phenomenon needs a closer appraisal.

\section{African Literature and Anthropology}

Western anthropological reception, consumption and valuation of African literature are historical constants as detailed in the politics of representation sketched out in chapter one. While Western critical and reading habits cannot be entirely reduced to anthropology alone, without question it is foundational in metropolitan critical reception and lay or general readership of modern African literature. 
I reference originary Western Othering imperatives, such as anthropology, as an important factor in African literary history with a full awareness of the large percentage of anti-imperialist, anti-colonial and non-fetishsising African publishing undertaken by transnational houses like (Anglophone) Heinemann - especially in the 1960s. This is particularly true of Francophone Présence Africain in Paris during the heyday of Negritude and anti-colonialism. Although one cannot accurately describe that publishing concern as having ever been mainly a 'Western' establishment, its democratising program would however never have been possible without the support of the 'Western' Parisian Left of the day. Moreover metropolitan critical discourse and Africanist intellection have moved far beyond the narrow confines of classic anthropology since the 1960s when African literature was just emerging. It is therefore important to note that what is significant for my central claim - that third-generation novels self-anthropologise - is the 'trace' and residue of the fetishsised beginnings of African literature rather than a static and an undifferentiated Ur-anthropology.

In their more overarching studies of that idea of anthropological trace in postcolonial literatures Brouillette and Huggan agree on postcolonial writers' (un)conscious exotic self-positioning vis-à-vis the global market at the centre. The latter refers to postcolonial writers response as being occasioned by a "strategic exoticism" (Postcolonial Exotic 32) while the former echoes it by analysing the self-consciousness of Derek Walcott's travel motives, which negotiates a strategic "insider-outsider positioning" (Global Literary Marketplace 27) as a migrant Caribbean writer living in the USA. Huggan, referring to André lefevere (1983), proffers a very apt insight into the 
market logic of such positionings and the contradictions it involves, especially where African literature is concerned. He is worth quoting at length:

African writers are often caught between the desire to achieve recognition - and the financial rewards that come with it - with a wider audience and their awareness of the constraints this might place on their writing and the ways in which it is received. The danger exists, for example, of the edges of a certain, unmistakably politicised kind of writing becoming blunted by a coterie of publishers and other marketing agents anxious to exploit it for its 'exotic' appeal. (35)

To a considerable extent, I have described the distant contours of a contemporary anthropological trace in African literature in chapter one's discussion of the Western reception history of PWD. I will now elaborate upon that by juxtaposing PWD with a surprisingly earlier example, and two comparatively more recent variations, of anthropology in African literary texts. This will be in the background of that surprisingly contemporary - even if contested - critical validation of anthropology or ethnography by Christopher Miller in Theories of Africans.

There can be no doubt that it is precisely because of an anthropological trace that Christopher Miller insists, while acknowledging progressive changes in Western critical reading of African texts (Theory of Africans 2-5), that "a fair Western reading of African literature demands engagement with, and even dependence on anthropology" (4). Critics from Amuta, Quayson to Huggan have variously contested that assertion (see Postcolonial Exotic 2002: 37-39). Miller seems to re-appropriate a past era when the cultural imperialism of the colonial project stood at an ethnocentric distance from Africa 
as an anthropological object ${ }^{54}$ in which - in Johannes Fabian's temporal conception "the Other's empirical presence turns into his theoretical absence" (Time and the Other 1983:xi). That historical epistemological lacuna is the reasons for Miller's argument that "without some reliance on anthropological texts, Westerners will not be able to read African literatures in any adequate way" (21). According to him new African (especially Francophone) writers seem to have internalised that "anthropological rhetoric" (6) - a description of the devices "by which cultures are represented to each other" (6).

In highlighting the relationship between anthropology and literature Miller provides the example of explanatory and ethnographic endnotes, glossaries or in-text parenthesis, which might accompany texts and, provide the distant foreign reader useful "cultural information" (6). The investment of anthropology in literary production, consumption, and valuation, as it is understood in this dissertation, transcends Miller's acknowledgement of its conscious and merely 'explanatory' or didactic effects. I am concerned with anthropology as an unconscious discursive formation, a "structure of feeling," (Williams Culture and Society 1958: 39) which envelops the Western reader, some new African writers and their Western publishers - rather than a Western critical establishment, which has transcended the limitations of Ur-anthropology. While admitting to an anthropological trace in the consumption of African literature Huggan nevertheless strongly contest Miller's assertion that anthropology is indispensable and necessary for a western reading of contemporary of African literature (Postcolonial Exotic $38 \mathrm{ff}$ )

An anthropological trace, or a self-anthropologising narrative strategy, is

\footnotetext{
${ }^{54}$ In Johannes Fabian's formulation "Anthropology has been constructing its object - the Other - by employing various devices of temporal distancing, negating the coeval existence of the object and subject of its discourse" (1983:50).
} 
discernible in the subtexts of the novels produced by a cross-section of third generation African writers and in the type of works that attract metropolitan consecration through literary prizes and academic institutional validation. While it can be argued that Tutuola's work was not anthropological as far as authorial intent is concerned; that PWD merely displays the writer's honest linguistic limitation of an uneducated writer; and that he was simply consumed and marketed as anthropological due to metropolitan bias for primitivism, there is a clear case of an early and clearly self-anthropologising text. A review of the said work will establish that and exemplify the resilience of an anthropological trace in sundry contemporary third generation writing and in their reciprocal or enabling general metropolitan reading public's taste for the exotic. A selfanthropologising discursive impulse was already evident in the narrative strategy of the very 'first' African novel in English. Unlike Ethiopia Unbound (Casely-Hayford 1911), "which lacks a narrative structure and [where] the technique is discursive rather than aesthetic (Michelman "West African Novel" 1976:31), Love in Ebony, published in 1932 - twenty years before Tutuola's PWD - is structurally a novel, but one whose subtext was suffused with an anthropological impulse like PWD.

Frederic Michelman highlights foundational Western fetishsisation of African literature by drawing attention to Love in Ebony's self-anthropologising narrative strategy as a response to metropolitan patronage systems. He says of the author of the romance novel in question: "Karlee naturally writes from the point of view of a coastal AmericoLiberian $^{55}$ and seems to cater to Western appetites for exotica: woven into the narrative

${ }^{55}$ Robert July in "Didactic Writing" (in European Language Writing Gerard ed. 1982: 71ff) describes the Americo-Liberian as elitist $18^{\text {th }}$ century returnee American slaves placed higher up on the Sierra-Leonian social ladder than the indigene. The returnees identified with the metropolis and owed moral allegiance to the centre. Charles Cooper (born in 1896) is the real name of the author of Ebony in Love, who wrote under 
are descriptions of the secret Porrow cult, the festival following Ramadan, the Muslim month of fasting, and other anthropological material" (32).

Apart from the above, there is an added sense in which we can deduce that anthropology was coincident with the inception of African writing because Low's publication history of PWD notes that Tutuola's anthropological novel, with its staggering metropolitan success, "signified a certain commodifiable vision of Africanness - a virtue to cultivate or a vice to veer from" ("Natural Artist" 17). Although Low says that this metropolitan fascination was "for a brief period of time" (17) only, nevertheless it was the inspiration for Allan Hill's formation of the African Writers Series and, of course, that series is largely responsible for the internationalisation and initial token canonisation of African writing. The foundational modality for the Western valuation of African literature is as such anthropological in the main. Low is worth quoting at length at this point:

Hill's championing of Chinua Achebe, whose Things Fall Apart was published in 1958, can be read in part as a reaction to the style and content of African writing that was associated with Tutuola. Hill cast Achebe's work, and subsequently the creation and marketing of the African Writers Series, as a foil to the type of African writing that Tutuola personified for the publishing world. In contrast to Tutuola's "linguistic virtuosity or plain illiteracy," Hill wrote of Achebe's work that it seemed adept at rendering "traditional tribal society" in terms that "the Western-educated reader could understand" (121). (17)

The originary market logic of western publishing structures' anthropologising of African

the pseudonym, Varfelli Karlee (ibid. 101). Like Tutuola's work Cooper's romance novel is simple, perhaps for reasons other than a lack of education - Cooper studied at Liberia College and was a SierraLeonean diplomat in the UK (101). 
literature as described above is transmuted into an anthropological trace as it is displayed again in contemporary times through a metropolitan publishers' privileging of South African fiction depicting the black South African male as a sexual danger vis-à-vis the white South African woman. That stereotype recalls late "nineteenth and early twentieth century" (Graham "Rape in Coetzee's Disgrace" 2003: 432) discourse of the "the black peril" (433ff). The 'black peril' phenomenon captures a "period of social hysteria prevalent in South Africa from 1890 to 1914" [and] "reflected white anxieties in times of social and economic crisis" (453). J.M. Coatzee's Disgrace is the occasion for this example of anthropological trace.

The main plot of Disgrace involves three black men gang-raping a white woman on a South African farm, juxtaposed with a sub-plot in which Lurie, a white male university professor, violates one of his black female students. The first act of gang-rape is brutal, overwhelming, heavily racialised and evokes the black peril while the second act, while equally racialised, is narrated as an aberration - at least from Lurie's viewpoint as he defends it as consensual. The result is a textual authorial ambivalence, where one act of rape has an anthropological force and is more resonant than the other. White male rape of a black woman is understood by Graham as a deliberate authorial counterpoint for the black peril and read as the 'white peril.' But the emphasis here is on the depiction of a wayward, unrestrained and dangerous black sexuality represented as the gang rape of a white woman. Graham's reading of Laurie's 'consensual act' as an authorial genuflection to an equal 'white peril' is tame beside the brutality of the gang rape. This anthropological exotic of the sexual kind is reminiscent of a European representation of the black male as a "penis symbol" (Fanon Black Skin; White Mask 159; see also Zack 
1997: 153, Hyam Empire and Sexuality 204).

What is significant here is that the kind of sexual stereotype implicit in Disgrace, is intrinsic to the novel's market value. "Internationally, it would appear that 'black peril' representations have been highly marketable" ("Rape in Coetzee's Disgrace" 434). Graham supports that assertion with an important anecdote. "In 1950, Doris Lessing's New York publisher, Alfred Knopf, told Lessing they would consider 'The Grass is Singing' for publication if she would modify that manuscript to accommodate an explicit rape of the white female protagonist by Moses, a black man: 'in accordance', as the publishers put it, "with the mores of the country"' (435ff).

Even though Lessing objects to the racialised ideological prompt from her publishers, the house of Alfred Knopf nevertheless proceeded to publish the manuscript with a paperback graphics depicting images and symbols reminiscent of sexual 'danger' and the black peril. "When the novel came out in paperback, the writer was shocked to find on its front cover 'a lurid picture of a blond cowering terrified while a big buck nigger stood over her [the white heroine], threatening her with a panga' (436-437). Graham's conclusion that "in the minds of publishers at least, such 'porno-tropics' evidently made for lucrative publications" (437; my emphasis), once again, confirms the working of the anthropological exotic in contemporary Western literary valuation of African literature. She suggests that the huge metropolitan critical and commercial success of Disgrace when it came out "may be attributed to similar [anthropological] international appetite" (437).

Apart from publishers' literary valuation as mediated by the metropolitan reader's consumption of African literature, Western academic critique of African literature was 
originally founded on the anthropological. Critics of African literature as disparate in their approaches as the Marxist, Chidi Amuta (Theory of African Literature) ${ }^{56}$, the aforementioned anthropologist, Christopher Miller, postcolonial theorists, Ato Quayson (Strategic Transformations 1997: 2), an already much cited Graham Huggan, Sarah Brouillette (Global Literary Marketplace 2007), and African Americanist, Henry Louis Gates (Loose Canons 1992: 88) are all agreed on the foundational influence of anthropology in African literature. Even if they deploy different concepts - for example, "literary anthropology" (Strategic Transformations 2), or "cultural anthropological criticism" (Theory of African Literature 22) there is a general consensus on the influence of an anthropological trace or in Huggan's words, an 'anthropological exotic' or the "postcolonial exotic",57 in "the global literary marketplace" (Brouillette 2007).

Much earlier, in 1976, Wole Soyinka made the subject of a Western conflation of African literature with anthropology the backdrop of an elaborate exploration and affirmation of African poetics in relation to its traditional ritualistic and mythic

\footnotetext{
${ }^{56}$ In the wake of the IMF and corruption-induced destruction of the middle class in the early 1980 s into the 1990s, Amuta has since abandoned his Marxist leanings. Like many leftist intellectual of the day he joined forces with the reigning despot, infamously nicknamed in the local press as "the evil-genus," or "Maradona" for his political dribbles, Ibrahim Badamosi Babangida (IBB). (See a Reuters News report by Matthew Tostevin at <http://blogs.reuters.com/africanews/2010/04/12/nigeria-return-of-the$\% \mathrm{E} 2 \% 80 \% 9$ Cevil-genius $\% \mathrm{E} 2 \% 80 \% 9 \mathrm{D} />$. Accessed 5 October 2012). IBB made it a point to dribble a lot of the intellectual left by dangling positions and huge bribes in a time of austerity. Amuta first worked for the General, overseeing the Directorate of Food, Roads and Rural Infrastructure (DFFRI). Predictably he was fired 'for doing a bad job' (see Onome "IBB and Amuta have Run Out of Luck" $\mathrm{http}$ ://againstbabangida.com/Super-Bloggers/ibb-and-amuta-have-run-out-of-luck-by-mark-onome.html>. Accessed 14 September 2012). He lost class credibility the IBB way. We can conjecture that having broken ranks with his Marxist 'comrades,' and then been 'dribbled' into a fall by IBB, Amuta could not join the left anymore. He next wrote a glowing biography of the General, titled Prince of the Niger: The Babangida Years (Spectrum Books: 1992), and followed much later by IBB: A Heritage of Reform Vol. $1 \& 2$ - edited with Baba Yunus Mohammed. Other compromised intellectuals and their works are, according to Reuben Abati - writing before he, in turn, became compromised and joined Jonathan Goodluck's goverment as image maker - "Foundations of A New Nigeria by Sam Oyovbaire and Tunji Olagunju, and Transition to Democracy in Nigeria (1985-1993) by Tunji Olagunju, Adele Jinadu and Sam Oyovbaire (Spectrum, 1993)" (see Abati "IBB: What Heritage" at http://www.dawodu.com/ibb.htm>. Accessed September 12 2012).

${ }^{57}$ See also Simon Gikandi's essay in the volume edited by him, Reading the African Novel (1987: 149).
} 
imagination in Myth, Literature and the African World. An anecdote in that work's preface recounts Soyinka's experience of the Western Academy's foundational anthropological critical tendencies. While there was a bonafide African literature programme in 1973 at Sheffield University's department of English where Soyinka was a visiting professor at the same time as he was a Churchill Fellow at Cambridge, he discovered that a similar programme at the latter institution was considered an anathema. The Department of Social Anthropology proposed "[...] a series of lectures on Literature and society $[\ldots]$ in which the Department of English was, naturally, to participate. [...] The lectures were duly given, but they took place entirely in the Department of Social Anthropology. Casual probing after it was all over indicated that the Department of English [...] did not believe in any such mythical beast as 'African Literature'" (vii).

In the same connection Soyinka notes that one of his student's research on "mythopoeia in black literature" (vii) at Cambridge would have met with certain disapproval had he (Soyinka) not been around to provide supervision. It turns out that the student in question is Harvard University's Henry Louis Gates Jr. Wole Soyinka, according to Gates, whose doctoral work in literature was supervised by the former at Cambridge University, was "forced to take an appointment in social anthropology, of all things!" ("What is Black Literature" in Loose Canons 88). Gates' anecdote, in a similar strain, also mentions how the critic Emmanuel Obiechina had to carry out a doctoral research in African literature through the Department of Anthropology at Cambridge (88). Obviously Cambridge did not recognise African Literature as a legitimate area of study (Stec "Publishing and Canonicity" 1997: 142). 
This Cambridge example only exposes the more invisible institutional ethnographic policing of African literature specifically or African Studies generally through Western academic institutional arrest, labelling, regulation and control. This is a phenomenon Zeleza (The Study of Africa Vol. 2, 2007) describes as "the disciplining" (12) of African Studies by "the disciplines" (12). That regime of disciplinary 'accreditation' or 'ratification,' 'interdiction,' 'controlled' study and institutionalisation is mediated by a primordial Eurocentric anthropological and ethnocentric view of Africa. "In their encounters with Africa, the disciplines have travelled a considerable distance from their unadulterated Eurocentric origins, but many traces remain which continue to envelope Africa in the analytical shadows of difference and even derision" (12). Again it is that idea of 'trace' that is the bases for my insistence that anthropology still has a bearing in shaping metropolitan market demands for, and publishers' supply of, particular variants of contemporary African writing that is (therefore) self-anthropologising.

The hermeneutic 'waywarding' of Africa that Zeleza refers to in The Study of Africa as a "Eurocentric construction of African exceptionalism" (12) has an unconscious appeal for third generation writers, some of whom textually and discursively reproduce its attendant "commodification of African exoticism" ("Natural Artist" 21). Third generation writing ornamented with self-anthropologising tropes is likely to be consecrated at the centre and receive laurels like the Caine prize, which especially targets this group of writers. Consequently those new writers whose work conforms to selfanthropology are tokenly included into pedagogical and literary canons at the centre. Nevertheless such inclusion is carried out in terms that maintain the power structures of the global canon. According to Wail Hassan ("World Literature" 2000), "the selective 
inclusion of non-Western texts in critical and pedagogical cadres often reveals new configurations of power and domination" (38; see also Eaton "Imaginary Versus Pedagogical Canons" 308).

Canonical revision at the centre is carried out through "limited inclusion" ("Canon after Postcolonial Studies" 298). This is the incorporation of 'representative' minor literature, a predilection of a multicultural 'world literature' phase of postcolonial studies, which results in the "hypercanonization" (298) of a few postcolonial texts, such as Things Fall Apart, or in the case of the third generation African writer, Chimamanda Adichie's Half of a Yellow Sun or Tsitsi Dangaremgba's Nervous Conditions. This is all to the exclusion of a much larger library ${ }^{58}$.

\section{Global Canonical Exclusion and Thematic Shifts}

The result of the limiting global canonising dynamics that I have been discussing is that contemporary African writers self-position within a competitive field of global cultural production in such a manner as to allow themselves the greatest access to metropolitan publishing structure, that is, to print capital and possible global visibility.

While some of these new writers' narrative and ideological stances might be said conform to the whims of the market at the centre they are also ironically subversive and self-empowering. In other words, a narrative ambivalence is interwoven into the third generation's self-anthropologising rhetorical strategy. While third generation African writers appear to pander to the anthropological registers of global literary consumption, they manage to disturb and reorganise the power dynamics of the global canon through a token admission into it. The subtexts of the new novels manage to dismantle the Western

\footnotetext{
${ }^{58}$ For details see Sallah Dean Assaf Hassan (2001), Walli Hassan (2000), Gallagher (2001), Mark Eaton (2001)
} 
Othering imperatives, which make these writers seem to self-anthropologising in the first place. I will proffer an example of such narrative ambivalence in the subtext of Lola Shoneyin's The Secret Lives of Baba Segi's Wives below in chapter three. For now there is a need for an appraisal of the thematic divergences between the first and second generations of Nigerian writers and the third. This is to underscore reasons for the latter group's ideological and thematic shifts and its need for a self-anthropologising rhetoric.

There is an existential continuum between third generation Nigerian writing's self-anthropologising themes and narrative strategies and the thematic preoccupation of the previous two generations. In chapter one I have already reviewed a rather common knowledge in Africanist literary scholarship - that the major narrative preoccupation of the first wave of African writers took the form of an ideological 'writing-back' to the centre's historical interpellations of the periphery. Most second generation and postindependence first generation literary production was inspired or rather 'weighed down' by the disillusion attending independence. This disillusion has been inherited by the third generation.

Informally referred to as "the mourning after" ("Political Voices" 259), postindependence disappointment and "postcolonial atrophy" ("Contemporary Theorising" 106) have been sufficiently discussed in the social science and in sociological literary critiques like that by Onoge (1974), Laurence (1968) and Griswold (2000), for example. Rather than rehash that discussion the focus here should be on the new writers' literary responses to a postcolonial atrophy that is continuous with a colonial ethos from which they are immediately removed. Despite discursive, ideological and temporal distances, which have resulted in a different temperament and thematic engagements, the third 
generation is united with their predecessors in a common obsession with themes of postcolonial dystopia. Recalibrated and intensified as a strategic exoticism, that dystopia suits the Western publishing market's imperatives for access to print capital.

As enumerated in chapter one, after independence Anglophone and Francophone African Writers belonging to preceding generations - some of whom are still practising moved beyond ideologies of cultural nationalism and writing-back themes and became enamoured, like most second and third generation writers, with the failures and corruption of comprador postcolonial dictatorships as subject in their works ("Political Voices" 259). Nigerian examples of literary production suffused by themes of dystopia in the genres of poetry fiction, drama, and social criticism, are to be found in the oeuvre of Wole Soyinka, Chinua Achebe, J. P. Clark-Bekederemo, Christopher Okigbo, Femi Osofisan, Tanure Ojaide, Kole Omotosho, Festus Iyayi, Ben Okri or Kenule Beeson Saro-wiwa.

The above qualifications apart, most first generation Anglophone African writers - nurtured by decolonising activism and a subsequent postcolonial disillusion with the new African nations - went beyond the scribal and resorted to extra-textual political activism buoyed further by social commentary and scholarly critiques of the postcolonial state. In Nigeria, the public discourses of Wole Soyinka and Chinua Achebe are notable as verifiable in such titles as The Open Sore of a Continent (Soyinka 1997), or The Trouble with Nigeria (Achebe 1984) and the prison memoirs, The Man Died (Soyinka 1972), A Day and a Month (Saro-Wiwa 1995). Saro-Wiwa's textual exertions took on a very physical character in the environmental activist role that led to an orchestrated prosecution and his judicial murder by hanging at the hands of General Sani Abacha's 
governmental in 1995. Soyinka was incarcerated between 1967 and 1969 because of his anti civil-war activities, and has been severally exiled until very recently. The Man Died is his prison memoir about that incarceration. Okigbo died fighting on the Biafran side of the Nigerian civil war of 1967 to 1970 . Achebe's recent controversial memoir, There Was a Country (2012) revisits that war and takes postcolonial angst to a divisive extreme in its promotion of ethnic Igbo nationalism.

Although the postcolonial dystopia superseding decolonization is continuous between generations to varying degrees, nowhere is it more profound than in the third. The African political upheavals, presaged in the global turbulence of the 1960 s, which is broadly defined in the poetics of older generations foreshadow the transitional postcolonial politics, ethics, ideology and textual, survivalist narrative strategies and themes that would come to characterise the third generation beginning in the 1980 s. Those born in 1960 could, naturally, only begin their literary careers (beyond apprenticeship periods and unpublished juvenilia) with actual textual production and local publication in their early twenties.

The thematic departure between the new writers and their predecessors, especially the first generation, is marked chiefly by the former's ideological abandonment reminiscent of what Leela Ghandi has referred to as "postcolonial amnesia" (1998:4) - of any concern for the cultural nationalism of the latter. I understand postcolonial amnesia not as conscious break with a painful past, " "a will-to-forget' " (4), or as the postcolonial state's need to erase the "painful memories of a colonial past" (4) but as all of that combined with a tendency to repress and psychically disconnect from that past. This can be said to be due to a surpassing of the sociology of the first half of the twentieth century 
into the late 1970s. By the 1980s, when writers of the third generation came of age, that past invaded their present: a prevailing disillusion turned to despair in their work as a reflection of lived experience. "The applause [of independence] died down with the collapse of the first civilian government in 1966. For the next decade and a half, Nigerians staggered from one political nightmare to another: coup d'états, assassinations, tribal pogroms, secession, and civil war" (Baker "Lurching Towards Unity" 1976:70). The hope of continental political gains and the promise of statist wellbeing and economic prosperity that came with 'flag independence' quickly dissipated and became disillusion.

The third generation's disillusion with the modern Nigerian State and its crippling existential conditions under corruption and International Monetary Fund's (IMF's) economic structural adjustment is well represented in Nigerian poetry of the 1980 s (Voices from the Fringe 1988; "Ibadan and Memory" 24ff) into the 1990s. It is ever more strident in the work of those poets still writing in the continent at the moment, reflecting worsening existential and political conditions, considering poetry collections with such 'desperate' titles as The Man Lived (Zakama, 2004), Lovesong for my Wasteland (Raji, 2005), Poems on the Run (Bassey, 2004), Intercepted (Bassey 1998). A cursory look at the signal publication of the 1980s, the generation-defining Voice from the Fringe will reveal that collective angst. Beyond a few personal musings and the lone, 'idle' idylls, that canonical poetry anthology is sober and dystopic indeed. The same existential quality is to be found in the simultaneously published individual collections of six new (Update) 
poets. ${ }^{59}$ Together these works are representative of the third generation's arrival on the Nigerian literary scene. A few examples of the poets' offering will suffice.

Emman Usman Shehu's poem, "Serenade," captures the abuse of power, political flamboyance and neglect of civic responsibility:

Wail-wail

Wail-wail

Wail-wail...

The sirens loudly blare telling us that you are here, riding on wheels of power.

Sir, are you passing-by, or this time stopping-by to see the ghettohood? (Voices From the Fringe 69)

Existential angst resonates in Tonkate Chiddy Opara's "Cries of a Ghetto Dweller:" "If I die/ In this ghetto,/ If I die/ In this squalor,/ My ghost shall haunt/ Their Excellencies [...] (72); or in "Memories:" Memories,/ Memories linger on,/ Memories of squalid abode./ Of ghetto neighbourhood,/ They linger on. / Memories of hunger/ Of poverty/ Not as subject of discourse /But as reality [...] / Memories of war (72). The existential angst reaches fever pitch in Jite Mene's "To the Moment," which also directly invokes a prevalent ontological generational dilemma: "Do not think me hard/if I do not cry/Because a man died/ He is out of the fight/ I cry for the living/ Those who are witnesses/ To the moment/ I cry for you and me/ For our generation/ The by-product / Of their wasted generation" (79). In "History Lesson," Ogaga Amogo Ogocha's appeal to a romantic Nigerian past as juxtaposed with postcolonial disillusion is framed by a direct

${ }^{59}$ Theses poets, including Uche Nduka, Esiaba Irobi, Afam Akeh, Emman Usnam Shebu, were referred to as Update poets because they were all introduced for the first time under an imprint of the same house, Update publishers. 
invocation of colonialism. Each line is deeply connotative of a universal social malaise, requiring the full body of the poem here:

They say once upon a time The sky canopy was so low People reached up and plucked stars

To make necklaces for their lovers.

Then there was a war And when the clouds cleared The Liver of the world Was very sick with ancient malarias Which statesmen tried to purge With pills more bitter than nivaquine, Soon after which the canals Of the Global systems Were flooded with finances Into which fissiparous amoebae Found ways somehow, whence They periodically cause regional dysenteries.

They say the ailments here

Started when we entered the world Through colonial gates

Soon after which oil bombs shattered all myths about us

To cut the story short They say everyone then

Stopped breeding birds here

Because there was no more feed

As mother earth no more

Bred worms, maggots etceteras [sic]. (82)

The above poem is a short overview of colonial history, the global upheavals following decolonisation, the discovery of oil in Nigeria in the 1950s, with its attendant illusion of affluence, and the economic disillusion following the adoption of the IMF's 'structural adjustment' of lives after the oil burst of the 1980 s, by which time the country had unfortunately abandoned agriculture as its main Gross Domestic product. The poem carries an undertone of official corruption and fiscal mismanagement. 
Under the name, Godwin Ede, one of my own early poems titled "Song" in the same anthology, is more of a dirge: "In the beginning/Hope started boldly from every look/All lurking ghost scattered gold/ As bright day startled the bird/ The heart leapt with the promise/ Of song// In the beginning// When faces did not twist with violent denial/ When madness was not locked beneath all movement/ Before the psyche struck up its serpent head/ Before voice deserted bird and bard/ And silence steeped the mind in painful song/ Echoing sweet forgotten melodies (2). A preponderance of the dystopia under the economic depression and corrupt dictatorships during the poetic renaissance of the 1980s into the 1990s and thereafter is captured eloquently in some of the interviews with representative third generation and older Nigerian writers in Holger Ehling and Claus-Peter Holste Von-Mutius' edited volume (2001), No Condition is Permanent: Nigerian Writing and Struggle for Democracy.

In the 1990s, the thematic convergences between the third generation and its predecessors became very sharp departures - still dystopic but rather in a strategic exotic, self-anthropologising manner - in tune with global market requirements for global canonisation. That stylistic and thematic shift was exacerbated by a progressively deteriorating economy, which was already forcing the literary renaissance in the country "to migrate abroad" (Voices from the Fringe xv). The decision by the Association of Nigerian Authors (ANA) to harvest the rich poetic efflorescence taking place was arrived at partly due to the new writers' "increasing[...] frustration [because of the inability] to find publishing outlets for their works" (xv).

From the 1990s onwards the relevance of third generation literary production to global canonisation is that a complex of existential angst, lack of local publishing 
infrastructure, or access to global print capital resulted in increasing civic alienation, partial exile, and a strategic recourse to self-anthropologising themes which expanded beyond the structural, formal and discursive limits of the poetic genre, and required the dialogism of the novel form (Bahktin "Epic and the Novel" in Dialogic Imagination 1981). Besides, the existential, ideological and political concerns of the new writers needed the more expansive "heterogeneous stylistic unities" (262) of the novel form for full articulation. According to M. M. Bakhtin, "the novel as a whole is a phenomenon multiform in style and variform in speech and voice. In it the investigator is confronted with several heterogeneous stylistic unities, often located at different linguistic levels and subject to different stylistic controls" ("Discourse in the Novel" in Dialogic Imagination 261).

In the contexts here, I understand Bakhtin's 'investigator' to be the author, specifically the third generation African writer. New writers' gravitation to a more 'plastic' genre was discursive as well as a strategic and conscious choice due not only to stylistic and thematic urgencies, but also to an interwoven complex of concerns, which includes the need to access print capital, anxieties about the metropolitan readers' taste, desire to reach a global target audience, all predicated on the market value of the novel form vis-à-vis poetry or any other genre.

After the oil bust of the 1980 s the poetic form, usually not the most lucrative for publishers anywhere, was not likely to attract print capital either locally or globally. Locally it was not unusual for poets to pay for the publication of their own work. A new cottage industry sprang up to satisfy demand for vanity publishing. Steve Shaba's Kraft Books in Ibadan, established in the 1990s, led that new development. He published and 
still publishes chiefly poetry under its "Kraft Griots" imprint. In discussing the profitability of Tutuola's PWD for the house of Faber and Faber, Gail Low notes that "[t]he literary lists of companies like Faber, William Heinemann, Michael Joseph, Cape, and Andre Deustch were successful in keeping up the necessary turnover because variety and diversity helped subsidize their more narrowly literary output" ("Natural Artist" 20). 'More narrowly literary output' included poetry, which value inhered in their cultural capital only and did not make profits. The publishing structure in the metropolis, to which new African writes were turning in the search for print and cultural capital, favoured the novel form. Global canon forming imperatives thus dictated genre, theme, style, apart from speeding up the alienation of a third generation already removed from the ideological concerns of their predecessors.

Paradigm shifts in African writing are deeply embedded in a relatively long history for a nevertheless young literature and are continuous, as may be expected, with the vicissitudes of the continent's insertion into modernity. As mentioned earlier, Omafume. F. Onoge describes the psychic condition of African modernity succinctly as one predominantly of a "crisis of consciousness" (1974). "Usually, African writers have phrased the problem [of a crisis of consciousness] under the conceptual rubric of 'role,' 'responsibility' or 'commitment' of the writer to his society. While critics, African and foreign, have generally posed it in terms of the validity of the sociological character of the contents of the bulk of the literature" (386). And very importantly in literary production, metropolitan publishers, one might add, have internalised the African condition in terms of the stereotypical images of an embattled Africa that the average Western reader expects, and which is therefore marketable. This very critique, this 
dissertation in its queries, is also inevitably and ironically in the grip of, and a result of, that crisis of consciousness.

That crisis is uniform across all generations of African writing even if it suffuses the poetics of the first and second generations more thickly, that is, in a more realpolitical manner. We see the resilience and a resurgence of a crisis of consciousness in Achebe's aforementioned work, There was a Country, where he rarefies a moribund secessionist Biafra, and vilifies the Nigerian State via the person of Chief Obafemi Awolowo, who was in the opposing camp. The more subtle inflections and tonalities of a crisis of consciousness in third generation writing can be said to be due to contemporary writers' focus on the postcolonial state, rather than history, as the source of existential lack (Politics of the Belly 1993). Such redirection of literary ire upon a depersonalised African state is also a consequence of the new writers' alienation from and ambivalence towards that state. It is in that sense that these writers also direct their work at a metropolitan publishing structure and audience at the ideological expense of the postcolonial state.

The initial dominance of poetry in black aesthetics has a historical significance beyond immediate market dynamics. During the emergence of African writing in the Black Atlantic, and within the political ferment of black internationalism, the creative writing genre most suited to capturing a crisis of consciousness was poetry - although there were other forms such as theoretical and philosophical exegesis, apart from fiction, that formed the founding texts of African literature. Poetry's uniqueness resided in its capacity for urgency in tone and delivery - for example in capturing the immediacy of traumatic colonial or new world experiences. And here I am considering 'African 
writing' as emerging from a 'trans-modern' library beginning in the eighteenth century and based on the studies by Robert July (1968) and Jahnheinz Jahn (1968), Adam Potkay and Sandra Burr (1995), Henry Louis Gates Jr. (1987), Charles T. Davies and Henry Louis Gates Jr. (1985) ${ }^{60}$, Vincent Caretta and Philip Gould (2001), Henry Louis Gates Jr. and William L. Andrews (1998:82-180).

If we abide by William Wordsworth's definition of poetry as a sudden burst of "powerful emotions ("Preface" in Lyrical Ballads 1786), it should encompass the written as well as those verbal spontaneities that inspired and resulted in the former. It will include such sudden verbal outbursts like the work song, and dirge on the slave plantation or sugar cane field. These could not have been "recollected in tranquillity" - as the second part of Wordsworth's proposition defines poetry to be - but would have been the result of consistent psychic and mental agitation, deprived of the "backward scanning" (Goody 1977:128 qtd. in Ong "Orality and Literacy" in Mccleary and Finkelstein Book History Reader 2002: 115) of writing as a technology. This would then precede the 'tranquil recollection' and subversive stance insinuated in Phyllis Wheatley's textual as opposed to verbal/aural poetic contestation of modernity - contestation in the sense that her ability to write contradicts a central defence of slavery, namely that the slave had no cognition.

Phyllis Wheatley's 1773 poetry collection is a " 'reply' [to the] modern 'challenge' " (Dussel "World Systems," 2002: 221). By her appropriation of the western sign, Wheatley performs a political act, unwittingly disproves the Eurocentric conflation

\footnotetext{
${ }^{60}$ Henry Louis Gates Jr. and Charles T. Davies delimit the Slave Narrative as being only those writings about the slave's story "published before 1865" (1985: xii). Nevertheless the idea of a 'library' of countermodernity considers all works published in the black Atlantic as forming a library, as such, and includes works published after 1865 into the present.
} 
of writing with cognitive intelligence and superiority and unsettles part of the logic of slavery - that " black people cannot not write" (Gates "Race, Writing and Difference" 1993: 9) and are therefore less than human. She becomes, along with many other slaves, the distant precursor of that black " 'trans'-Modernity"61 (ibid 221) out of which African literature evolved. Wheatley foreshadowed the full-fledged black internationalist protest tradition through poetry - early twentieth century Parisian African Negritude poetry, Harlem Renaissance poetry in New York both in conversation with the poetry of indigeneism and Negrismo in Haiti and Cuba respectively (Jahn Neo-African Literature 1968: $214 \mathrm{ff})$.

Finally between the publication of Leopold Sedar Senghor's An Anthology of the New Negro and Malagasy Poetry in French in 1948 and the beginning of decolonisation on the African continent in 1957, the anti-colonial poetic pamphleteering of African politician-nationalists in the 1950 s and South African anti-apartheid poetry completed the reign of poetry as the dominant genre of modern African writing during a tumultuous period whose global disjuncture's and continuities is captured in Frederic Jameson's aforementioned "Periodizing the 60s." The reign of poetry as a genre of protest, alongside prose, lasted much longer in South Africa due to that country's longer anticolonial struggle far into the $20^{\text {th }}$ century until 1994 . The same is true for other parts of a larger Southern Africa such as Angola and Mozambique.

As I insinuate above, a crisis of consciousness in African literature begins properly in the new world despite Onoge's situating of it within the colonial period and beyond. As such poets as physically separated as Phyllis Wheatley in the Black Atlantic,

${ }^{61}$ See also Pius Adesanmi's "Redefining Paris: Trans-Modernity and the Francophone African Migritude Fiction" Modern Fiction Studies 51.4 (winter 20005): 958-975 for an elaboration of this phenomenon in African aesthetics. 
Countee Cullen or Langston Hughes of the Harlem Renaissance, Leopold Senghor, Gontran Damas and Aime Cessaire of the Negritude Movement, Dennis Brutus of antiapartheid South Africa, Augustino Neto in Mozambique, Reggie Ammatoe of Ghana, and Philippe Thoby-Marcelin and Luis Pales Matos, both members of the Haitian Indigénisme and Cuban/Puerto Rican Negrismo respectively (Neo-African Literature 215,220 ), are psychically united in various thematic preoccupation with a crisis of consciousness and through the poetic form.

While poetry was suitable for quickly capturing the trauma of a New World passage, arrival and dispersal, colonialism and anti-colonial/anti-apartheid agitation, the crisis of consciousness in African literature took on other tonalities with increasing temporal distance from the continent's most cataclysmic epochs. And the further away the continent moved from colonialism into flag independence, and a postcolonial dispensation, the more disparate the tonality in that crisis of consciousness as compared to its appearance in previous literary works. The third generation's temporal distance from colonialism has become far away enough for a 'postcolonial amnesia' to take hold of new writers and lead to a scribal strategy of (un)conscious ideological acquiescence with the demonic images of Africa, which earlier generations fought against (largely in verse and) in prose. New writers' ideological distance to the postcolonial state is a function of, and is seamlessly interwoven with, global publishing market dynamics, and its accompanying genre and thematic preferment.

It is important to note that in contemporary African writing, as in any literature, genre, theme and ideology are almost indistinguishably intermeshed in their operations and effects. This is because in the case of Nigeria's third generation Adesanmi and 
Dunton (2005: 10ff) ascribe a genre shift to "the phenomenal rise of three novelist" (10) - Helon Habila, Chris Abani, and Chimamanda Ngozi Adichie. In light of the arguments above, I submit that these successful new writers' international consecration and global acclaim cannot be independent of the conscious or unconscious strategic exoticism of their work. The next, and subsequent chapters will explore the phenomenon of the selfanthropologising novel and related concerns. 


\section{Chapter Three}

\section{Narrative Moment and the Self-Anthropologising Novel}

In responding to global publishing and market structures, canon forming institutional preferment and metropolitan consumption, a large number of new African writers invest in self-anthropologising themes and narrative strategies in the novel form as noted in chapter two. Strategic-exotic narratives, which unwittingly perpetuate demonic images of Africa, can be said to be a continuation of the crisis of consciousness in African literature. One aspect of that sustained crisis is the contemporary African writer's personal dilemma as a subject positioned historically to be powerless within the field of global cultural production. The writer's striving for literary consecration and global visibility then leads to the ironic problematic that he or she wittingly or unwittingly perpetuates stereotypes about the continent and its culture.

An ongoing related critical as opposed to literary variation of the crisis of consciousness exists in the global virtual public sphere where commentators in opposing camps quarrel over whether new literary works are merely realistic fictional 'documentations' of the 'unpleasant' facts of everyday life in Africa, or simply a philistinic ideological conformity to Western stereotypes of the continent. The latter view is often and most stridently the general consensus. The public intellectual and book reviewer, Ikhide Ikheloa, is a tireless proponent of that view. In the context of the annual heavily contested and already institutional British Caine Prize for African Writing he considers new African writers' self-positioning as a betrayal of the continent. His conclusion, in a review of the 2011 competition, is that "[ $[$ ]hey [the new writers] are 
viewing Africa through a very narrow prism, all in a bid to win the Caine Prize" ("How not to Write about Africa" Next Newspapers 2011) ${ }^{62}$.

The 'narrow prism' he refers to is those Western stereotypes, which new African writing seems to incessantly project every Caine prize award season. His essay echoes and alludes to a similar one, "How to Write About Africa," by Binyanwanga Wainaina published much earlier in 2005 in British Granta Magazine. Although Wainaina is himself a Caine Prize laureate, he is morally positioned to launch such a critique since his award-winning short story, "Discovering Home" (2001), cannot be said to be selfanthropologising. It is the story of a symbolic self-discovery couched in an internal exile's literal physical journey across Africa towards his roots. "Discovering Home" is an unusual ideological exception to the general strategic-exotic tendency of Caine-prizewinning stories.

Wainaina's essay is a satire on an age-old and still contemporaneous Western image and media representation of Africa. In a tongue-in-cheek manner he addresses the ideological fixity of the average Western tourist/commentator and advises the imaginary foreign chronicler on Africa to "[e]stablish early on that your liberalism is impeccable, and mention near the beginning how much you love Africa, how you fell in love with the place and can't live without her."63 One could say that Ikheloa's approach critiques the new African writers' 'complicity' with Wainaina's foreign chronicler. According to the former, "[t]he creation of a prize for 'African writing' may have created the unintended

\footnotetext{
${ }^{62}$ This article first appeared in the now defunct Nigerian Next Newspapers in May 2011. It is republished on Ikheloa's online blog at <http://xokigbo.wordpress.com/2012/03/11/the-2011-caine-prize-how-not-towrite-about-africa/>. Accessed 19 October 2012.

${ }^{63}$ First published in Granta 92 . See <http://www.granta.com/Archive/92/How-to-Write-about-Africa/Page1>. Accessed 19 October 2012.
} 
effect of breeding writers willing to stereotype Africa for glory" ("How not to Write About Africa").

The new African writer's self-anthropologising is so formulaic that Ikheloa could easily predict the winner out of five short-listed stories for the year 2011 ahead of the award announcement: "Medalie may not get the Caine Prize. His story is not African enough. No rapists, no murderers, no poverty [...]. Bulawayo would be my pick for the prize. She sure can write, unfortunately her muse insists on sniffing around Africa's sewers." And indeed NoViolet Bulawayo does go on to win the 2011 Caine prize. This is because, literary quality apart, her story is the most stereotypically demonising and selfanthropologising of the entries. "Zimbabwe's NoViolet Bulawayo has a fly-ridden piece, Hitting Budapest [sic], about a roaming band of urchins, one of them impregnated by her grandfather - at age ten" (ibid).

Although incest is imaginable in the domestic realm, its occurrence would be nevertheless very unnatural and occasioned by unique contexts deriving from psychological or psychoanalytic dysfunction. In her fictional world Bulawayo does not provide a context for that curious incidence of incest, the result of which, apart from being uncanny, is the impregnation of a ten-year-old child, Chipo. As the street urchins, and narration, get on their way, all we learn is the sensational declaration, "Chipo, $[\ldots]$ used to outrun everybody in Paradise but not anymore because her grandfather made her pregnant." While the narrative economy of "Hitting Budapest" (Boston Review 2010) is intrinsic to its aesthetic efficacy, this astringent, over-contraction could easily result in textual instability and render the work amenable to being interpreted as factual through a Western imaginary, which reads African fiction as windows onto the continent in what

${ }^{64}$ See <http://www.bostonreview.net/BR35.6/bulawayo.php>. Accessed $20^{\text {th }}$ October, 2012 
Graham Huggan, Ato Quayson and Simon Gikandi have all suggested to be an anthropological one-on-one correspondence as discussed earlier.

There is another aspect of the manifestation of the crisis of consciousness in African literature, which Ikheloa equally tirelessly critiques on Internet groups, listserves social media and on his blog. This is the extra-textual, wayward migrant identity politics which some of these new writers deploy in order to bolster the credibility of their selfanthropologising fictional creations, on the one hand, as well as to draw sympathy to their personal fortune as exiles, on the other. In a manner of speaking the fictional spills out of the pages of the novel and colours the writer's daily life as professional prop. The most successful and visible of the new generation of writers live in the literary capitals of the world due, more or less, to a previously discussed migrational impulse of the 1990s in search of publishing outlets amongst other existential reasons. "A significant proportion of [successful] third generation African writers are now located in Euro-America. Virtually every known producer of Francophone African fiction in the generation is based in Paris. Nigeria accounts for the highest rate of third generation exile [from] Anglophone Africa" ("Contemporary Theorising" 110).

The notable appearance of a younger generation of practising African writers in Western metropolises inflects the Euro-American critical rubrics for reading the new works being produced. As the old themes and styles give way to the new so do theoretical exertions seek to apprehend the developments. "[D]isplacement, deracination, exile, alienation, and diaspora have become the [Western] discursive categories with which the modalities of being" (106) of the third generation writer is interpellated. That transitional reading strategy is often not necessarily textual but literary-historical or extra textual and 
it insinuates itself to the migrant writer. The result is that some of these émigre writers 'novelise' their own lives and create personality cults around themselves.

Identity politics might take the form of a cultivated eccentricity, idiosyncrasy, and conscious self-gendering, or an assumed persona sometimes anchored upon and couched in pre-exilic, life-threatening real-political terms ${ }^{65}$. Some writers insinuate or directly lay claim to outlandish and fantastic tales of persecution and endangerment by the postcolonial state, consequent upon their 'fleeing' into exile. Given the all-too-familiar phenomenon of Africa's corrupt postcolonial dictator regimes and their repression of freedom of speech, such tales of persecution often go unquestioned (because they confirm the preconceived image of Africa) by Western literary patrons and audiences and make for brisk book sales. In other words in their self-anthropologising, some of these migrant and exiled writers do not only 'write blackness,' they perform it. While such performativity might take all kinds of unique forms or shapes, its one unifying characteristic is its bad faith (Sartre Being and Nothingness 1956). Simply put, some third generation émigré writers resurrect a historically familiar metropolitan black persona - the performing 'black face,' an indispensable figure of black internationalist Paris in the era of early-twentieth century black primitivism ${ }^{66}$.

\footnotetext{
${ }^{65}$ For example see Ikhide R. Ikheloa's accusations against Chris Abani in "The Trials Of Chris Abani And The Power Of Empty Words" at <http://saharareporters.com/article/trials-chris-abani-and-power-emptywords-ikhide-r-ikheloa>. Accessed 20 October 2012. See also "Chris Abani: Distorting Africa's History" at $<$ http://xokigbo.wordpress.com/2011/12/03/chris-abani-distorting-africas-history/>. Accessed 20 October 2012.

${ }^{66}$ This is exemplified in the symbolic figure of Josephine Baker on the Parisian stage as singer and celebrity in the 1920s and 1930s. She was nevertheless the subject of intense French public debate as to whether a black woman can be described as beautiful. While Baker performed blackness for an admiring French public, its ambivalence is nevertheless clear from such public questioning of her humanity, the topic of race and beauty being the entrée into questions about human equality. See Bennetta Jules-Rosette's Black Paris (1998) particularly the chapter, "The Dialogue between French anthropology and Black Paris."
} 
The combination of new textualities with self-anthropologising themes and sensational narrative strategies, further 'haloed' by extra-textual identity politics based on personal tales of dislocation has potent market value, a potential for attracting metropolitan prizes and its resultant consecration and canonical status. Observers like Ikheloa have wondered aloud at the seeming naivety of the metropolitan audience or at the new writers' 'calculation.' It should however not be forgotten that these actions and the metropolitan audiences' responses to them - even if both might seem conscious at some levels - are discursive and historically determined. While the third generation writer appears to be a native informant complicit in the demonisation of Africa, it is remarkable that his or her fictional creation is mostly based on real unpleasant facts of the African quotidian, even when heavily embellished and sensationalised. Moreover it should also be noted that, due to postcolonial amnesia, the new African writer does not have the ideological commitment of the first two generations nor feel or owe any real allegiance to the continent.

The cultural nationalism of the 1950 s and 1960 s has been overtaken by lethargy or numbness induced by the failure of the postcolonial state, the comprador antics of rogue regimes, and the subsequent fragmentation of the very idea of nationhood and belonging - in the case of Nigeria at the least. Besides, the new writers, in positioning themselves as agents within the field of cultural production, are responding to market forces shaped by the economic imperatives of postcolonial lack. Perhaps the ideological problematic of self-anthropologising texts consists in their overly simple, subjective narration of 'facts' without foregrounding fictional events in surrounding objective contexts, historical or otherwise - to do which would require ideological sensitivity and a 
comprehensive vision. It is, nevertheless, difficult to demand ideological commitment from a generation of writers, which is alienated from its founding history and from the idea of nation. That alienation is complicated by the condition of migrancy and exile, which circumscribes most successful third generation literary productions.

And no matter the seeming naivety of metropolitan audiences, these are very sophisticated readers, who are simply trapped in millennial perceptions about the dark continent.' This has created an African exceptionalism in the Western imaginary, which assumes that every fictional piece of African writing, particularly in so far as it is 'dark,' has to be an accurate rather than a fictional or a 'factional' depiction of the postcolony. The existential conditions in those fictional worlds, exaggerated or not, exist in the metropolis as well in certain degrees, nevertheless a 'global' reader would understand them as an exception not the rule - if they do occur in, say, an American, a British, or a German novel. Beyond or precisely because of foundational anthropological perception of the continent, African exceptionalism is made possible and sustained by a phenomenon I posit as 'narrative moment' - of which it is also a function.

A narrative moment consists of a 'narratable' event or events, and cultural phenomena, which take on the nature of 'event' as well. My concept of narrative moment (in both singular and plural senses) is simply one made up of a historical or contemporary event or series of events of large or small import in the public or private sphere, affecting individuals or collectives, which can inspire (especially) fictional or factional narratives or even the memoir or autobiography. It is important to note that events might have the potential for narration but that narrative moments yield their promise only when actually textualised. As suggested above narrative moments do not necessarily only result in 
fictional writing. Some lives constitute a narrative moment and attract textualisation. The life-writing conception of a narrative moment is one that contemplates it as standing out because of its remarkable nature. The hallmark of a narrative moment is its uniqueness or its being rendered as unique. Such events have nothing to do with ethics; they are simply events, which are remarkable for ill or good and which press upon the creative senses the need to be recorded as history or transformed as creative text or as artistic or cinematic work. In a manner of speaking, then, the real is a place suffused with such moments in different configurations and on periodic bases - daily, monthly, yearly, epochal or millennial.

We can find quick examples of narrative moments - the World Wars, slavery, the Jewish holocaust, and in terms of public figures whose lives constitute such moments historical personages who have had a massive impact in particular spheres - Adolf Hitler, Alexander the Great, Plato, Shakespeare etc. As an event in contemporary times the September 11, 2001 attack on the American World Trade Centre buildings - the Twin Towers - in New York, constitutes a narrative moment. So do recent tsunamis in Asia, which caused so much destruction and took so many lives. The ongoing political revolution in the Middle East, commonly referred to as the 'Arab spring,' is a very good example of a narrative moment should it be made the subject of literature or film. Of significance to the strategic-exotic in African literature is the intersection of narrative moments with stereotype and, hence, anthropology.

When a narrative moment recurs in a certain pattern within a given geographical space and becomes, through the force of repetition, the means or only way for (mis)understanding the character of that space, it exhibits tendencies of a negative 
anthropology and of stereotype. In teasing out the intersection between narrative moment, anthropology and stereotype, I will borrow Bakhtin's concept of the literary chronotope. In "Forms of Time and of the Chronotope in the Novel" (op cit 84ff), Bakhtin defines a chronotope as "the intrinsic connectedness of temporal and spatial relationships that are artistically expressed in literature" (84). His space-time equation, borrowed from Einstein's relativity theory, apprehends plot and its duration and/or trajectory - that is, its time of narration - as space and time respectively. Based on the relationship of those two categories and depending on genre, he exemplifies how both categories result in a unified and recurrent narrative and structural coherence in particular types of novels - for example, in the romance. In this structuralist way he shows that the essential difference between all romances or particular novels belonging to a similar genre is only a sum of the variation in their respective chronotopes; the essential features are repetitive and predictable. In my reading, that predictability is a kind of 'stereotype.'

A narrative moment, in its chronotopic consistence, shares something of 'predictability' through the force of its repetition. But it is only ideology, which renders that repetition as a negative stereotype in the way a romance novel beside one hundred other romance novels with similar chronotopes in different combinations is not stereotypical. That ideology is the force of an Othering anthropology as it is applied to African narrative moments. As discussed earlier we find this active in the ideology of the black peril in South African literature and how it anthropologically typecasts the black South African male in Coetzee's Disgrace, a novelisation of post-apartheid narrative moments of incessant rape. Beyond questions of race, that novel is not framed within 
larger historical socio-political, economic apartheid-era contexts as they relate to postapartheid social dysfunction, of which the problem of rape is just one aspect.

While the phenomenon of the narrative moment is neither geo-specific nor necessarily limited to Africa, its manifestations on the continent - in the form of, for example, corrupt governments - has been discursively and un-historically mapped in the Western media as Africa-essential. This African exceptionalism can also be attributed to the continent's eternal crisis of consciousness, which itself is informed by a series of permanent narrative moments in the global unconscious: in overarching terms - slavery, colonialism, modern dependency, internal strife, hunger, poverty, dictatorships ad infinitum. These diachronic 'narratable' accretions, reinforced by a decontextualised media representation, lead to synchronic Western internalisation of Africa as a place of ravages. It also results in Western stereotypical reading strategies, and a mimetic expectation, which the new ideologically non-committed writer uncritically represents artistically.

Third generation African writing's strategic-exotic responses to stereotypical narrative moments in the African socious fall into discernible patterns based on recurrent themes. In an exploration of the relationship between the global postcolonial literary market, audience and literary craft, Akin Adesokan highlights five general features typical - not just of new African novels but of recent global postcolonial fiction - which "have become so dominant as to be viewed as the gold standard, especially when that standard turns on the attractions of a big money prize or the bestseller list" ("New African Writing and the Question of Audience" 2012: 4). Such works "are mostly written by women; they are focalized from the perspectives of culturally innocent or 
marginal protagonists; they thematize the emotional consequences of familial or public upheavals; they are not too long, but if they are, they compensate for their length by being formally or linguistically nonexperimental; and they end happily, or at any rate, not too grimly" (ibid.).

Unlike Adesokan's identitarian and structural rubrics for categorising new postcolonial fiction, my typology for delineating self-anthropologising African novels due to their narrative specificity and paradigmatic nature - is based mostly on their thematic preoccupation. Nevertheless questions of authorial identity are germane in indirect, extra-textual ways as discussed briefly above and as will be further demonstrated. My invocation of narrative strategy will emphasise the sensationalising of already stereotypical African narrative moments, which might include but are not limited to continental events and themes such as hunger and famine, war, disease, corruption, environmental degradation, sexual abuse, the traffic in women and prostitution, and cultural events like polygamy, female genital mutilation, bride price and political dictatorships, amongst others.

It is important that, just like Adesokan's cautionary note about homogenisation, there are exceptions - like Teju Cole's Open City or Sefi Attah's Everything Good Will Come - to the self-anthropolgising novel. It is against this background that I will now proceed to attempt a close reading of major third generation novels in the selfanthropologising mode. For purposes of structural tidiness I will read those works with similar themes interactively and as a group due to their unifying narrative strategies and those that are wildly variegated, if any, as isolated examples of thematic divergence visà-vis the trend under focus. 
It is possible from the evidence of what has been published since the 1990 s when the novel became the ascendant genre for the third generation Anglophone or Francophone African writer to establish novels dealing with the following themes: war and child soldiers, crime and corruption, sexual trafficking and prostitution, sexual transgression, dystopia, incest, political anarchy, poverty - or a combination of any of those categories. This list is not necessarily exhaustive or final but is only a tentative working grid as derived from observable common themes of strategic exoticism.

At this juncture I will exemplify self-anthropology in practice through a close reading of some representative third generation texts invested in some of the previously listed themes. The limitation of this work, of course, does not allow for a more expansive engagement with each and every single theme as listed. Pointing to the semantic subtleties of one or two of these texts, I will exemplify how self-anthropolgy does not necessarily just pander to Western taste but is also an act of ironic and subversive agency for these writers.

\section{War and Child Soldiers}

In responding to the global market requirements of metropolitan publishing, some third generation Nigerian writing start out with ethnographically arresting titles such as Beast of no Nation (Iweala 2005), The Secret Lives of Baba Segi's Wives (2010), Half of a Yellow Sun (Adichie, 2006), I Do not Come to You by Chance (Nwuabani, 2009), Say you are One of Them (2008), On Black Sister Street (2009), or Doing Dangerously well (2010) and Prison Notes or Waiting for an Angel (2004) and so on.

The above titles do not all necessarily reveal the self-anthropologising proclivities of the works at a first glance, even if some of them give such indications. But a close 
reading of an example of such texts will reveal the predominance of images, tropes, subjects and themes, which conform to Western stereotypes about Africa. The argument can be made that the subject of these novels mimic the real accurately. As I have argued above it is not so much the narrative moments being fictionalised that is a problematic but the decontextualised and parochial manner of the fictionalisation.

The subject of war and the child soldier phenomenon are two of the beloved subjects of strategic exoticism, with their accompanying evocations of horror and human degradation. They have become so stereotypical and universal in the Western imaginary that a "Penguin anthology of contemporary African Writing" published in the USA as recently as 2009 is titled Gods and Soldiers (Spillman) in celebration of an Africa of ravages. The title is exaggerated, anthropologising and ironic - if only because none of the writings in the anthology, except an excerpt from Chimamanda Adichie's Half of a Yellow Sun, is about war or (child) soldiers.

The anthology is a collocation of writing by visible older writers and acclaimed or promising younger ones and does not really need the stereotype of that title to market it. Nevertheless habits of representation and patterns of the consumption of an exotic Africa in the West have clearly taken over. This is emphasised by a problematic structuring of content whereby much older writers like Chinua Achebe or Ngugi wa Thiong'o are juxtaposed with emergent ones in a work described as 'contemporary,' and where there is no definitive central organising rubric - in terms of theme, geography, or genre. It is a loose selection of writings from the essay to short fiction. What is remarkable about Gods and Soldiers, edited by someone who is not a trained critic or a specialist 'Africanist,' is that it makes expert claims - in its introduction and in its effort at scholarly 'design.' In 
the process it becomes just another allegory of a frozen image of primordial Africa in the Western imagination. Its anthropological imperatives become a genuflection to metropolitan literary establishments' market requirements.

A close reading of some third generation works invested in the war or child soldier subject will exemplify how exchange value dictates sensationalising narrative strategies. A quintessential work in this mode is Chimamanda Ngozi Adichie's Half of a Yellow Sun - quintessential because, from all appearances, it is a masterful prose of great moral force, merely concerned with re-enacting the tragedy of the injustice suffered by the Igbo during Nigeria's civil war. But its mastery conceals its self-anthropologising narrative strategy.

Half of a Yellow Sun (HYS) is a novel with the Nigeria-Biafra civil war as its ideological setting. The respective distant and immediate historical background ${ }^{67}$ to that war are the British imposition of nationhood on peoples with disparate cultures through the 1914 amalgamation decree and the threat of secession from this fragile union by one group, the Igbo of Eastern Nigerian, in 1966. The immediate catalyst of the war was a crisis around the transition of power. An anti-Igbo reprisal for the deaths of Northern Army officers felled in an abortive coup d'état, some of whose major actors where Igbo, resulted in the massacre of civilian Igbo in the North by Northern civilians. In protest the Igbo people decided to secede from the artificially yoked nation and declared the state of Biafra. The postcolonial Nigerian side made up of the major nation peoples - Yoruba, the avenging Hausa, and other smaller but significant nation groups - opposed such a

\footnotetext{
${ }^{67}$ Chidi Amuta provides a detailed historical and political background in "The Nigerian Civil War and the Evolution of Nigerian Literature." Jstor. Canadian Journal of African Literature (1983): 85-99.
} 
decision. The ensuing civil war, which lasted from 1967-1970, is one of the earliest narrative moments in the Nigerian state's young history.

While HYS is about war, it is also about love. The central theme of the injustice of the Nigerian war against Biafra is emphasised through the subject of the sacrifices and difficulties of love in an environment of war. The main characters, Odenigbo, a university professor, Olanna his lover, Richard the hesitant expatriate English man who desires the distant and enigmatic Kainene, Olanna sister, are all paired off in a love relationship where loyalties, endurance and personal strengths are strained and tested by the vicissitudes of war as Nigerian soldiers advance into the Igbo hinterland on the heels of the besieged lovers. The mysterious disappearance of Kainene at the end of the war and the pain of separation it brings for Olanna and Richard, sister and lover respectively, symbolises the irrecoverable losses and material dispossessions of that war.

An important subplot is the coming-of-age of Ugwu, Odenigbo's houseboy from the village. He develops from a rustic and sexually precocious almost pre-teen to an educated young man whose maturity and growing wisdom is measured at the end of the novel by the reader's sudden meta-fictional realisation that Ugwu is the omniscient narrator of HYS. It is a memorial he pens about the war and dedicates to his deceased 'Master,' Odenigbo, to whose social level he has now being elevated by this sheer intellectual achievement. A well-conceived and tightly woven narrative, the subtext of the work however displays a self-anthropologising narrative strategy which can be better highlighted when juxtaposed with War Games (WG), Dulue Mbachu's novel on the same subject of the Nigeria-Biafra war.

Like HYS, War Games' setting is the tumultuous Nigeria of 1967-1970. While 
HYS is a near-tragic story of love in a time of war with an omniscient and 'wise' narrator, WG, an Entwicklungsroman, is told from the perspective of a five-year old boy, Basil Chekwubechukwu Odukwe, also known as Cheche, whose innocence is a heartrending reminder of the tragedy of war. For the innocent child-narrator, war is a game adults indulge in - hence the title of the novel. War Games' understating of the NigeriaBiafra war only emphasises that conflict's tragedy and its serious dehumanising conditions. The child's narrative perspective adopted by Mbachu allows for a more objective representation of a harrowing historical event. For example Cheche recounts the prologue to the war with a child's non-judgemental observation: "[s]ections of Jos were often engulfed in riots, with reports that Hausa and other northerners were attacking and killing Igbos. Markets and businesses would close in panic and people would rush to the relative safety of their houses" (16-17). The innocent recounting of events is underscored in the child's bemusement at the inscrutable and senseless ways of adults:

I now realised I was Igbo and wondered what I had done to deserve such hatred. The adults said it was because the other tribes (sic) were envious of our success in commerce, the civil service and other fields. I wondered how they came to single out the Igbos as the common enemy. Did they hold a meeting somewhere to decide it? No one seemed ready to provide an answer. (17)

Narrating from the position of the kind of unsullied innocence displayed above, which makes Cheche and his friends play with bullets and grenades after the war to disastrous consequences (161), War Games, narrated as it is by an innocent child-protagonist, is objective in a tragic way. It does not sensationalise its historical setting, nor is it selfanthropologising - that is, the narration is not allegorical in the sense of narrating Africa 
as a stereotypical place of senseless ravages as it is the ideological tendency in HYS. For Cheche the Biafran war is a war like any other and just as senseless and catastrophic. WG's objectivity is emphasised by its humanising characterisation of the victorious 'enemy' Nigerian soldiers at the end of the war:

It was one full week after this incident when the first federal soldiers entered Amafor. We had heard they had set up camp at the Umunkwo Aiport. From there they moved into the surrounding towns and villages, where they conducted house-to-house searches. Many adults had anticipated this long before and had buried whatever weapons they had in the bush, mostly hunting guns and doublebarrelled rifles. To our surprise, and contrary to our fears, the federal soldiers were friendly. There were even reports they gave food and clothing to children in other places. Some adults were apprehensive and warned children not to accept their presents, that some of the items may have been poisoned. But I knew several children who took them and nothing happened. [...] Papa wasn't home but uncle Emeka led them from room to room where they searched every nook and cranny. And ordered drawers, cupboards and boxes to be opened. At one point, the sergeant saw two tins of Peak milk and said he wanted them. I was surprised that he should demonstrate such greed, having heard that the federal soldiers were the ones who had been giving things to the defeated people and not the other way around. $(167-168)$

Against the objectivity of War Games and its clinical prose HYS is emotive and powerful, rightly disgruntled with the prosecution of the war, its injustices, deprivations sufferings and the isolation of the Igbo. 
HYS' suppressed indignation is judiciously realised within the moral universe of the story. The nearness and imminent danger to, and possible extinction of, the Igbo is captured well in Olanna's nervous ruminations between Mrs Muokelu's glorification of the Igbo rebel army's war prowess, her taunting of the Nigerian army's ineptitude, and the intermittent wails of sirens (278-279): "The siren did not go off early in the morning, and so when the fierce wah-wah-wah sounds of the bombers appeared from nowhere, as Olanna dissolved corn flower to make Baby's pap, she knew somebody would die" (280).

The emotiveness of the prose is constantly underscored by passages such as the following in reference to Olanna's mental processes during a raid: "Death was the only thing that made any sense as she hunched underground, plucked some soil, rubbed it between her fingers, and waited for the bunker to explode" (280). Or in the same scenario: "[s]he was the first to climb out of the bunker. A woman had thrown herself down near the body of a child and was rolling around in the dirt, crying. 'Gowon, what have I done to you?'," Gowon being the incumbent Nigerian military head of state and chief antagonist of the Igbo. The narrative strategy of treating the Nigerian-Biafra civil war in powerful emotive prose, leads to an unstable text, namely one that is justified in excoriating the war but which simultaneously performs a blanket demonization of the rest of Nigeria, consisting of more than 250 nations peoples, as a undifferentiated group of 'vandals' $(280,281)$ or 'heathens' opposed to the Igbo.

HYS narrative strategy deliberately loses sight of the injustices and atrocities that might have been committed against minorities trapped between warring major nation groups - the aggressor Hausa rank and file and their political leaders, with Yoruba political rather than 'popular' support, against the Igbo. The binary opposition of evil 
versus good between Gowon, symbolising Nigeria, and Ojukwu as archetype for the Igbo respectively is emphasised by Olanna's pupil, Nkinuka, a school-girl-artist who, in drawing the two men, "shaded contours into the faces and, with a few strokes of her pencil, gave Gowon a snarl and His Excellency a grin [...] I want to kill all the vandals miss..." (281), Nkiruka proffers when she hands in her drawing. "[...] She was smiling the smile of a precocious child who knew she had said the right thing" (ibid.). In the rigid binary opposition between a monolithic and evil Nigeria and an innocent Biafra victim, the harrowing stories of the minority nations trapped between both groups disappear. HYS becomes a "single story" ${ }^{68, " ~(A d i c h i e ~ T E D T a l k ~ " T h e ~ D a n g e r ~ o f ~ a ~ S i n g l e ~ S t o r y " ~}$ 2009).

Although in "African Authenticity and the Biafran Experience," (2008) Adichie insists that she did not intend to romanticise the war. However, this is what the text of HYS does through unbalanced characterisation and a uni-dimensional narration:

But I wanted to write a novel. I had no interest in writing a polemic. I was aware that the book would in the end reflect my worldview - it would be a book concerned with the ordinary person, $a$ book with unapologetic Biafran sympathies, but also a book that would absolutely refuse to romanticize the war. I was very aware, as I wrote, of the problem that often comes with being a defeated people - and the Igbo are in many ways a defeated people. It is not only that you learn to bear a collective shame, but that you sometimes go to extremes of reaction. (50; My emphasis)

\footnotetext{
${ }^{68} \mathrm{See}<\mathrm{http}: / /$ www.mtls.ca/issue5/writings-essay-azuonye.php $>$ for Nnorom Azuonye's response - "What is Illuminating about Adichie's 'The Danger of a Single Story'?" - to Adichie's Tedtalk presentation about 'single stories.'
} 
The contradictions in the above passage when placed beside Half of Yellow Sun's narrative strategy only confirm the ambivalencies at the heart of postcolonial nationhood. Adichie narrates the nation from its fringes and performs an Igbocentric discourse in an age where Igbo nationalism, in self-distinction from the Nigerian, is ever more in ascendance (Nwakanma Narrative of the Nation, 2008). With the publication of Chinua Achebe's There was a Country (2012), a recumbent Igbo nationalism, cynicism, and alienation from the Nigerian state has been given renewed vigour. Achebe has deliberately pulled off the scab of old wounds about forty years after the event. Controversy and division is the result of renewed disaffection and sharpened antagonisms in the global public sphere due to a subjective text.

In fiction just as in Achebe's memoir, the narrative moment of that war is sensationalised and enlarged against a similar exaggeration in the characterisation of Ugwu. His unusual libidinal traits suggest the act of reading in HYS to be voyeuristic - at once a spectacle of unbridled black sexuality as refracted through Ugwu's phallic annunciation, and African barbarity in war. At a mere thirteen years old, Ugwu is obsessed with 'breasts and buttocks' when the story opens and throughout the major part of the novel. "They - her breasts - were the images saved for the last on the many nights when he touched himself, slowly at first and then vigorously until a muffled moan escaped him" (9): this, about an unsophisticated village boy new to the city as house-help to Odenigbo in the early 1960 s. This characterisation sensationalises black sexuality.

In Three Essays on Sexuality (2000), Freud elaborates on the autoerotic sexuality of infants and children during the latency period ( $42 \mathrm{ff}$ ), in which sexuality focuses on 'an object' in puberty (73). However, Uwgu's libidinal urges, indiscriminate at puberty or 
any other stage during his growth, are polymorphously perverse like that of Freud's toddler or prostitute; his objects change according to erotic possibilities. Even in the thick of the war, with fear of air raids and sudden death or conscription into the Biafran Army, his fantasy is forever engaged with several real and imagined sexual objects. This conforms to that Western stereotypes of an overactive black sexuality ${ }^{69}$ severally discussed by various critics (Fanon Black Skin; White Masks 1967:158-160; Zack Race and Sex 1997: 153; Hyam Empire and Sexuality 1992: 203, 205). In fact Ugwu is "uncanny" in this regard and more of a perverse adult than a teenager and the sexual economy of HYS serves other ideological purposes, which are aligned to the semiotics of Hollywood and the market demands of print capitalism. This becomes obvious if Ugwu were to be juxtaposed with the child narrator in War Games.

Although not obsessed with sex like Ugwu, when he is confronted with sexuality Cheche however reacts with excitement like any young boy might, but he also displays a confusion that is natural at his age unlike the former's polymorphously perverse sexual behaviour. Once in the family rural retreat from the epicentres of war, Cheche finds himself in a compromising position with older girls at the village stream.

When we were done with all the washing, and because we were there, the girls decided we should take our baths before going home. Apparently, they had no qualms about being naked in my presence, obviously considering me still underage. But seeing them naked, hot blood coursed through my veins and my heart beat harder as I gazed at their different and yet similar female forms. [...] Betty, by contrast, had sizeable breasts, an ample backside and fat thighs, all of

\footnotetext{
${ }^{69}$ See Jose Piedra's "The Black Stud's Spanish Birth" where the stereotype of the oversexed black male is discussed at length. Piedra memorably refers to the Western perception of the sexual Other as "darker phallic forces" 827 .
} 
which trembled, making me tremble in sympathy. [...] It was Maggie who first noticed me staring at them; she also noticed something else and pointed at my groin as she called the other girls to take a look. They all burst out laughing. [...] I looked down and saw my penis standing stiff at right angles to my body. I had felt a straining there as if I was pressed to urinate but I was shocked to see how stiff it had grown. I was embarrassed and tried to cover my erection, which made them even laugh more. I started crying hot tears of shame. (113)

The realistic narration of War Games is consistent throughout the novel while HYS's exaggerations are equally consistent. The differences might, in part, be ascribed to the fact that in spite of similar subject, theme and equal emotional investment by two Igbo writers, the question of location refracts such investments drastically when placed side by side.

Adichie was based in the USA - at the time of writing, at least - Mbachu has always lived in Nigeria. Adichie never experienced the war and wrote from research, folklore and personal emotional investment. Mbachu was a young boy growing up during the war ("Narrative of the Nation" 13) and has had more than 40 years of reflection. It is clear that HYS is a "return narrative," ("Contemporary Theorising" 111), filled with the earnestness of the arriviste, while Mbachu explores familiar (emotional and physical) terrain. More importantly, HYS is also a return narrative in that significant anthropological sense in which transitional Western criticism of contemporary third generation African writing as the "diasporic texts of migrant cultural agents, [as...] a peep into the postcolony by a cultural agent who has escaped its "ravages" (Ibid.; my emphasis). 
What is important here in terms of global canonical exclusion and canonisation is that the unwitting romantic and victimological imaginative treatment of the NigeriaBiafra war in HYS sensationalises it. This narrative moment that is the Nigeria-Biafra war is enlarged as 'uncanny' spectacle. It is not the representation of conflict as a normal aberration of human society, but as a anthropologised spectacle of barbarians (the Nigerian side) at war. A chronotope of savage Africa is re-enacted in HYS. This exoticism in HYS then feeds stereotypes of an Africa of ravages, which is anthropologically consumed by Western readership.

Predictably, HYS, with its self-anthopologising narration, wins an important international literary prize - the Orange prize - and is recruited into the global canon. Nevertheless, it should be noted that HYS is by all means masterful narration and a wellcrafted work executed at a great level of literary art; it is well worth its consecration. But its strategic exotic narration consolidates any consecrating impetus in metropolitan canonical terms, even while the work ideologically demonizes. WG, on the other hand, having been published in the periphery, and with its objectivity, has not travelled beyond the borders of Nigeria. It remains a 'hidden' text.

Other notable works with the war-cum-child soldier motif are Nzodinma Iweala's Beast of No Nation (BNN) and Helon Habila's Measuring Time. Uzodinma's selfanthropologising is particularly all-embracing because it extends the localized war setting in HYS to allegorical proportions in $\mathrm{BNN}$, incorporating the whole continent since there is no specific geographical setting in $\mathrm{BNN}$. The whole of Africa becomes a war zone and is symbolic of war - especially war at its most bestial, considering the ghoulish boynarrator's automatic, almost psychopathic killing instincts. This points to an important 
characteristic of strategic exoticism, namely that it is not the matter but the manner of narration, which performs demonization. Any subject is a legitimate province for art depending on narrative strategy and ideological positions; otherwise strategic exoticism easily reduces a particular work to an anthropological window into darkest Africa. BNN is such a window.

BNN is comparable to Joseph Conrad's Heart of Darkness in its demonization of Africa. Without elaborating on his very remarkable observation that the novel infantilises the young narrator, Agu, Obi Nwakanma glosses the former's imposed inarticulacy ("Narrative of the Nation" 13). But it is a similar phenomenon, namely the rendering of African characters speechless, as displayed in Conrad's novel, which is central to Achebe's polemical and much debated reference to Conrad as a "bloody racist" and his work as a patronising sentimentality ("An Image of Africa" in Massachusetts Review 1977). Through its protagonist, Agu, BNN replicates the inarticulacy of Conrad's African Characters in Heart of Darkness. Much like the latter Iweala's character is given a "babble of uncouth sounds" instead of proper speech. Of course it can be argued that any kind of characterisation in a novel serves merely to foreground its plot within a fictional context. Nevertheless the subtext of BNN suggests that its narrative strategy does not merely serve purposes of verisimilitude in the work, given the cultural context of the novel. Nigeria alone has over 250 languages, apart from the common uniting pidgin for the uneducated mass across indigenous language barriers. A Nigerian character who can barely speak any of those languages is hardly credible.

Agu's inarticulacy is symbolic of 'a return to origins,' since it is not explained by plot or yoked to any important narrative insight more than to the fact that this boy-solider 
is uneducated and even incapable of the simplest thought in clear pidgin, a language so universal that every child and most uneducated adults take refuge in it. Nor could Agu speak his own native tongue. Instead he descends into a Conradian incoherence, alleviated by a 'gerunding': "It is starting like this [...] I am opening my eyes and there is light all around me coming into the dark through hole in the roof, crossing like net above my body. Then I am feeling my body crunched up like one small mouse in the corner when the light is coming on" (my emphasis 1). All that even though he says: "I am learning how to read very early in my life from my mother and my father" (emphasis added 24). And this child-solider who sings soldier soldier /kill kill kill / that is how you livelthat is how you die in order to remind himself of his fate, motivate himself against remorse, does indeed know the difference between a verb and a gerund after all. Here the author interrupts the characterisation and breaks the illusion by reverting to almost proper English in 'that is how you die/ that is how you live.' It is clear that character is a sensationalised caricature, projecting the Western stereotype of a barbaric continent of brutish child soldiers. Agu's journey through life is much like Marlow's, travelling up the course of the Congo river through unmediated nightmarish human barbarity.

BNN deviates from HYS and WG through its 'direct' allegorising of Africa generally as a continent principally of child-soldiers and of war and pestilence; a good selling point for Western consumers of the Dark Continent ${ }^{70}$. The incessant brutality in this allegory exists for its own sake. The main character, a child-soldier, is not developed

\footnotetext{
${ }^{70}$ The danger of such politically unballanced "statements" as BNN is that their ideologically unaware authors then present themselves as the faces and voices of Africa in international circuits, who critique the West's exoticisation of the continent. This is exemplified in Uzodinma Iweala's (author of BNN) Washington Post displeasure over the 'western messianic complex.' After writing a book like BNN, providing stereotypical ammunition for such messianic imperatives, one would expect that he should not be the one to complain. See stop "Trying to Save Africa" at <http://www.washingtonpost.com/wpdyn/content/article/2007/07/13/AR2007071301714.html>. Accessed 10 April 2009.
} 
beyond his personification of something out of Dante's hell. It is "the horror, the horror!" all over again after Heart of Darkness.

Like the previous novels the subject of Measuring Time (MT) is war and to some degree the idea of the child soldier since Lamamo, the mostly absent protagonist, is still a boy when he runs off to war. Like HYS it is a well-crafted narrative but again like the previous novel it borders on and is prone to over-writing with its epic insistence. It is the story of two brothers, twins, who are separated by their increasingly different ambitions and strengths as they grow. The anaemic Mamo remains home to become the quiet intellectual while Lamamo, the would-be artist and adventure-seeker, runs off to become a mercenary, fighting all over the continent as far as Liberia.

Again, it is narrative strategy which declares MT as self-anthropologising. The setting seems to be deliberately rustic, as rural as Africa 'ought' to be. The insinuation of stereotype surfaces when Lamamo passes through the cities in his travels and there are no descriptions of those places. Africa in MT becomes one sprawling village stuck in the past. Perhaps Achebe could have written a Things Fall Apart in the 1950s with its rustic setting as an organic universe in its own right within its project of setting tradition against modernity. However in MT, set in contemporary Africa, there are no geographies of the "Capital" as against the detailed descriptions of the rustic setting of Keti village, in the background of war. Between Things Fall Apart and MT, time seems to have frozen. As such MT borrows the pastoral map of Things Fall Apart but merely promotes Western stereotypes of a rural Africa immobilized forever in time. The suspicion of a sensationalised, strategic-exotic narration is confirmed when Lamamo returns home from his domestic and foreign campaigns as a battle-hardened adult and is ironically killed the 
very next day in a mere village disturbance while leading a riot. Lamamo, who miraculously did not get injured or maimed in all his deadly domestic and foreign campaigns as a soldier since boyhood returns home, leads an on-going insurrection and is dead in less than forty-eight hours. Apparently the war had served its purpose - that of confirming Africa as a place of ravages 'alone' - and the shadow protagonist, whom the reader experiences only through his letters and his paintings of current environments during his travels as soldier of fortune is not really developed. He has served his selfanthropologising purpose, conveniently dies, and the novel ends shortly after. This anticlimatic denouement and melodrama reinforces an exotic narrative strategy.

\section{Crime and Corruption}

Adaobi Tricia Nwuabani's I Do Not Come to You is the story of Kingsley O. Ibe, an otherwise very honest but jobless graduate, who succumbs to crime due to economic pressures. A simple enough plot apparently. What is not so simple is the author's strategic choice of subject matter. Western media representation of general African official corruption, resultant impoverishment of the continent's masses, their forced migrations to Euro-America and sometimes recourse to global internet economic crimes, which has come to be synonymous with Nigeria, is a near-universal narrative moment in the global public sphere.

In such a scenario any writer who tackles as subject matter Nigerian Internet crime, known as the 419 scam after a sub-section of that country's local criminal code, positions himself or herself strategically within the field of global cultural production in terms of the market value of an already sensational subject. Depending on the narrative strategy adopted the resulting tale might easily devolve into self-anthropologising, further 
projecting the global stereotypes of the exceptional 'Nigerian criminal' opposed to a 'crimeless' global community. This is what occurs with Nwuabani's handling of the plot of I Do Not Come to You. A straightforward narration of a fraudulent group of Nigerians led by the kingpin, Cash Daddy, simplifies the complex psychology at work in a crime such as this.

Kingsley $\mathrm{O}$. Ibe becomes a reluctant but increasingly brazen and adept writer of scam letters to potential dupes at the end of the world. The title of the novel echoes one of the catchphrases in these electronic letters, with their persuasive and deterministic tone: 'I do not come to you by chance; it is fated.' Or 'fate has brought easy fortune your way.' The proposal usually follows a pattern, which has come to be aptly termed 'advance fee fraud' in global criminology. Typically the dupe is offered an equal or considerably large share of a staggering sum of money if he or she would help in laundering the total sum to a foreign account in the dupe's name. Usually the dupe is tempted and succumbs, agreeing to become an accomplice.

Although the protagonist, Kingsley $\mathrm{O}$. Ibe, raised as he is in a morally upright Christian home by religious parents, initially has attacks of conscience, he soon grows callous with the flow of ill-gotten cash into his pockets, an elevated and flamboyant lifestyle, and the conscience-deadening pragmatism of his boss and uncle, Cash Daddy. Ibe ruminates after one of his white dupes who just happens to be seriously ill, poor and in dire straights, empties out savings, borrows and scrapes to pay 'advance fees' on a 'deal,' even promising good naturedly, in a familiar and friendly letter to her faceless 'business partner,' to maintain confidentiality and even send more advance fees in spite of her privation: 
This note caused my heart to crack. The poor woman would find herself in a cauldron of debt and disaster when the money [her expected share of sum to be laundered] she was expecting did not show up. Who knows what comforts the couple had forfeited in saving up to buy a house? What if she was actually hoping to start IVF treatment? Here was a real life happening behind the curtains of an email address. It was a bit unrealistic refunding what we had already eaten so far, but I thought, at least, we could shred the job. I spoke with cash daddy about the unique problem on our hands. (183)

Cash Daddy deadens Ibe's conscience with a series of rhetorical questions (to which the latter can only respond with a 'no'), which are meant to show the absurdity of empathy in a criminal enterprise, and draws on race, historical evidence as witness to the superfluity of sympathy. The following dialogue ensues:

"Kings," he [Cash Daddy] said when I finished explaining.

I waited.

"Kings," he called again

"yes, Cash Daddy?"

"This woman... what's her name?"

"Her name is Mirabelle."

"No, no, no ... what's her full name? Her Surname?"

"Winfrey. Mirabelle Winfrey"

He sighed deeply and shook his head remorsefully.

"Kings."

"Yes, Cash Daddy?"

"Is she your sister?"

I did not reply.

"Go on ... answer me. Is she your sister?"

"No." 
"Is she your cousin?"

"No."

"Is she your brother's wife?"

"No."

"Is she your mother's sister?"

"I got your point."

"Go on ... answer me"

"No."

He shrugged. Then as an afterthought: "Is she from your village?"

"No."

"So why are you swallowing Panadol for another person's headache?"

"Cash Daddy," I persisted, "the woman borrowed the money she's been using to pay her bills. Her life is going to be ruined."

He laughed.

"Kings, with all the school you went $[\ldots]$ Over there their governments know how to take good care of them. They don't know anything about suffering. $(183-184)$

Cash Daddy informs Ibe of the social welfare system in Euro-America, which will cushion any of their victims. He finally brushes aside any other qualms Ibe might have with a sophist, trick statement:

I was not pacified. He must have seen it in my face.

"Ok," he continued "You, you went to school. Did they not teach you about slave trade?"

"They did."

"Who were the people behind it? And all the things they stole from Africa, have they paid us back?" (185)

And to King's further protestation a final benumbing of the conscience: 
"Kings, sometimes I get worried about you. Your attitude is not money-friendly at all. If you continue talking like this, soon, whenever money sees you coming into a room it will just jump out through the window." (185)

I have quoted at length because this is the stage in the plot where narration becomes stereotypical. The exchange exemplifies how self-anthropology functions discursively within the text.

While Ibe's appears to be the voice of conscience, the narrative strategy of conducting the above conversation in the comic mode mocks that conscience, cancels out the scammer's redemptive move as false, half-hearted, duplicitous, and only consolidates the heartlessness of advance fee fraud. Cash Daddy's logical but false and ludicrous sophistry confirms that. This clearly is not satire but comedy. In this way the Nigerian scam artist is portrayed as a perfect scoundrel, and scamming is given a Nigerian character. The stereotype is complete. The fact that such crimes occur in the real world and are simultaneous with the very act of writing the novel gives currency to the crime and that Nigerian Image; it imbues text and world with an anthropological one-on-one correspondence, such that with its own unfolding, the text unfolds the world outside the text and they become continuous.

A more insidious consequence of a narrative strategy which treats the subject in the comic mode while 'worlding' the text simultaneously is that an apparent absorption with the surface structure of the text and its direct engagement of the real occludes the story of the Western dupes, and their complicity in the crimes of which they are dupes. The reason is that a focus on the dupes at the level of plot would destabilise the discursive construction of the stereotypical Nigerian criminal. A narration of the criminal 
intent of the faceless white characters would jeopardise and unravel the selfanthropologising structure of the novel, and its sensationalising appeal.

I Do Not Come to You confirms 'the Nigerian Image,' which was once informally inscribed in Western publics by no less a personage than America's General Colin Powell. In an increasingly media-shrunken world the power of narrative moment as a phenomenon is emphasised when Powell proclaims in a New Yorker interview that Nigerians "tend not to be honest. Nigerians as a group, frankly, are marvelous scammers. I mean it is in their national culture" (Nuhu-Koko qtd. in The Chronicle October 3, $1995)^{71}$. A spate of outraged global Nigerian public response followed. ${ }^{72}$ Understanding the power of a baseless but nevertheless prejudicial comment, the Nigerian Nobel Laureate for literature, Wole Soyinka, publicly rebuffed Powell. Both public figures understood, if towards different ideological intents, the power of narrative moments in the public sphere.

The moral is that narrative moments have a tendency to deteriorate into such stereotypes and have a strong appeal, not dissimilar to that of the metropolitan gossip mill, for western readerships. As a result of its strategic-exotic acquiescence with the narrative and market demands of global canonical exclusion I Do Not Come to You, not surprisingly, won the Africa region Commonwealth Writers prize for Best First Book. Much more than a simple innocent act of consecrating literary value, the prize puts a seal on stereotypes about Nigeria, and Africa by extension, as a peripheral locus of global crime and corruption.

\footnotetext{
${ }^{71}$ see $<$ http://www.dukechronicle.com/article/powells-offensive-remarks-criticized $>$. Accessed on 26 October, 2012

${ }^{72}$ There is a particularly virulent response to Powell's statement by irate Nigerian online. See Femi Akomolafe's "Feeling Sorry for Nigerian Scammers" at http://www.swans.com/library/art15/femia08.html>. Accessed 26 October 2012.
} 
There is no stronger consolidation of that narrative moment than a Canadian writer's winning of the 2012 Scotia-Giller prize for fiction prize with Will Ferguson's novel, which is simply titled, 419 . But not so simple is that its central plot is based on the fraudulent Internet activities of a group of Nigerian scam artists based in Lagos, whose criminal activities resonate a continent away and cause the apparent suicide of a victim in Canada. '419,' as explained earlier, is a number denoting the legal sub-section of the Nigerian criminal code set up to specifically address the internet fraud phenomenon. Just like Gods and Soldiers, the novel, 419, ironically exploits those narrative moments, which some contemporary Nigerian writers themselves perpetuate globally.

\section{Tales of Polygamy and the Modern Domestic Realm}

During the development of Western anthropology, African marriage and kinship systems have been a fascinating area of ethnographic enquiry. In Western literary anthropology, literary works with a focus on the domestic realm have a tendency to be read as ethnographic material. For example Miller notes "French-language literature of subSaharan Africa emerged at the same time (op. cit 6) as the new body of ethnography on Africa; the two bodies of writing produced versions of Africa in tandem [...that] were inextricably interwoven" (op cit 6).

Freud's (Three Essays 2000) reduction of the traditional Western family unit to a nuclear and monogamous 'daddy-mommy-me' equation discountenances metropolitan incidences of the polyamorous and polyvalent (Jankowiak and Mixson "American Spouse Exchange Community" in Jankowiak Intimacies 1983: 245) - or even of polyandry in other cultures like that of the Himalayas (Tiwari "Marriage in a Polyandrous Society" in Jankowiak Intimacies 1983: 122ff). Although critics like Deleuze and 
Guattari (Anti-Oedipus 1983) and Robert Young (Colonial Desire 1995) have critiqued Freud's concept of the Oedipus complex as a modern social/capitalist construct, its stabilising filial 'holy trinity' is still perceived in the Western imagination as 'normative,' while discrepancies are 'projected' (Adams Multicultural Imagination 1996: 166ff; in Fanon Black Skin, White Mask 1967:189ff) unto the periphery as the locus of polygamy. Usually occluded in this cultural narrative moment is the fact that kinship systems are occasioned by different modes of production, one capitalist and the other, agrarian.

A Western African exceptionalism imagines Africa as a place of sexual excess at the level of polygyny, amongst others indicators, despite major and radical changes in the continent's mode of production and a progressive departure from traditional marriage forms due to modernity. Narratives with polygamy as subject are then, of course, likely to have a fascinating exoticism for a metropolitan readership. Karin-King Aribisala's Our Wife and Other Stories (1990) is one of the earliest examples of third generation novels which engage polygamy. It duly received metropolitan consecration through the British Commonwealth Writers prize as mentioned in the introductory part of this dissertation.

Beyond the 1990s and after Aribisala's polygamist tale, Chimamanda Ngozi Adichie's first work, Purple Hibiscus (2003) is probably the next major third generation Nigerian novel about a modern African domestic realm - rather than about polygamy per se. Since the setting of this work is the African domestic realm, predictably it deploys a self-anthropologising narrative strategy as a gesture at 'verisimilitude,' perhaps. Purple Hibiscus is about the patriarchal excesses of 'papa' as terror in a Christian home he rules over with an iron hand. The work foreshadows a literary mastery confirmed in Adichie's 
second novel, Half of a Yellow Sun. As a work of literary art it is exemplary with its attention to detail, well-developed characters and a sustained narrative energy.

However what should simply remain a great novel becomes a great selfanthropologising novel due to narrative excess. This is because of papa's ironic barbarity - he is an anti-corruption crusader and fights for human rights in the public sphere and, as a Newspaper publisher, defends his employee-editors against torture by government agents. However within the domestic realm he becomes the torturer, a self-righteous Christian bigot, who pours boiling water over her daughter's feet because he is unhappy with her supposed poor grades. This figure hardly has any redeeming feature at home, but is a saint in the community. While such a characters might well be plausible, it is arguable that this extreme depiction of Papa has the strategic exotic goal of presenting an authentic modern African patriarch.

Adichie's descriptive strength is also what compromises the work and confirms its strategic exoticism. The figure of Eugene or 'papa,' the overbearing family man and ogre is so finely realised as a character that, at the same time, he borders on the fantastic or caricature. There is not one redeeming quality in this brutish cave man in the modern domestic realm, with his exaggerated Christian piety, who so harasses his family that his children, Kambili and Jaja, flee from him in terror; that his wife eventually poisons him; that his son, Jaja, had no choice but to redeem a long-suffering mother and falsely claim responsibility for his father's murder. The tragedy is completed with Jaja going to prison for a crime he did not commit. The narrative strategy of overstatement exposes the selfanthropologising subtexts of the novel. 
Lola Shoneyin's The Secret Lives of Baba Segi's Wives (2010) is a story about polygamy within the domestic realm. While the domestic setting in Purple Hibiscus is modern, middle class and non-polygamous, Secret Lives' setting is traditional and polygamous. However, like Purple Hibiscus, it is also a tale about patriarchy, domestic subjugation and female emasculation - apparently. Unlike Purple Hibiscus, Secret Lives is also about conjugal jealousy and intrigue within its polygamous context. But the women share a very dark secret, an unholy conspiracy, whose eventual revelation is the climax of the story; it sharply undermines the whole idea of maleness or patriarchal power.

Baba Segi, as patriarch of the realm, has four wives, Iya Segi being the first and Iya Tope, Iya Femi and Bolanle in that order. The first three are a group of conspirators sharing a most damaging secret between them. Apparently all four compete and vie for their husband's emotional and conjugal attention. The plot of the novel is built on the resulting intrigues between and amongst them. This is strongly undergirded by the aforementioned life of dark secrets - from marital infidelity to rape - which the three conspirators as a group and the youngest wife respectively carry in their hearts. There is a never-ending plot between the first three against the youngest wife, Bolanle. As the youngest, most beautiful and the only educated spouse, and not being included in the conspiracy between the other wives, she is considered an interloper and a threat to be expelled.

The main plot concerns Baba Segi's unhappiness about, and his obsession with finding a medical cure for, Bolanle's childlessness. This is in spite of his having already fathered seven children with his other three wives. His persistence leads to endless 
medical checks over a long period. Finally the suspicious gynaecologist, Dr. Dibia, request an interview with Baba Segi's most senior wife, lya Segi, who has already given birth to a girl and a boy in that order. Upon the doctor querying her in the presence of her husband about her past pregnancies, Iya Segi's reveals that, having noted Baba Segi's sterility early in their marriage, she allowed herself an extra-marital affair just to conceive. Dr Dibia, meaning to get to the bottom of the matter probed further:

"Are you saying your husband is not the biological father of your first child?" Dr Dibia asked. Eureka!

"Not my first, not my second."

$[\ldots]$

"And the other wives? What about their children?" Dr. Dibia asked. [...]

"I misled them. Perhaps if I had not shown the second one my way, this shame would have come out sooner. But you see, they were so desperate to be fruitful. They knew that my husband valued children above all things, so when I saw their desperation, I took pity on them and shared my secret. They followed the same path" (245).

Listening through the above conversation a dazed Baba Segi discovers for the first time that, after purportedly 'siring' seven children, he is actually sterile. The conspiring women have subverted and upended his secure patriarchal world.

While the narrative content of Secret Lives does indeed project the image of a stereotypical polygamous, poly-amorous, traditional domestic African realm made up of a harem of emasculated wives and an all-powerful patriarch, the subtext of the work displays a subversion of that domestic realm, the empowerment of women, who take control over their own bodies and reproductive organs and have agency. Ironically it is 
Baba Segi, several times a cuckold, whose masculinity is emasculated, who is robbed of agency due to his chauvinist worldview. The subtext of that novel displays a narrative ambivalence, which contradicts a mere pandering to Western exotic consumption even though Secret Lives' plot strategically succumbs to that perennial narrative moment of a static traditional African domestic order in which women are uniformly powerless under an unremitting patriarchal dominance.

Most self-anthropologising third generation novels perform the kind of subversive agency displayed in Secret Lives by appealing to the metropolitan market requirements of global canonisation, while at the same time upsetting the power dynamic within it, and powerfully positioning the writer vis-à-vis Western agents of consecration. Predictably Secret Lives was long-listed for the British Orange prize for women's writing in 2011 just as Purple Hibiscus, with the similar thematic concerns, was shortlisted for the same prize in 2004. That last work's self-anthopologising rhetoric is so powerful and overwhelmingly resonant that it was also longlisted for the Booker prize, won the Commonwealth Writers Prize in two major categories - first best book for the Africa region and overall best first book. This is apart from the cross-continental debut fiction Hurston-Wright Legacy Award in the USA for 2004. 


\section{Chapter Four}

\section{The Nigerian Canon and Cultural Identity}

He wants to divide the soul of Nigerian Literature, dictate where I can stay to do my writing, and outlaw good writing because it was not produced in his ghetto. ${ }^{73}$ (Ofeimun "The NLNG Literature Prize Controversy: Before The Nigerian Prize", Nigerian Guardian, 28 November 2004).

Preceding discussions clearly indicate that Western consecration of contemporary African literature through metropolitan literary prizes is central to its canonisation globally or locally. It is therefore pertinent to ask: 'in how far do local prizes perform a similar function?' This concern needs to be couched in terms of the very public identity politics of a recent initial exclusion of migrant Nigerian writers from participating in one such local literary competition, the NLNG Literature prize, which is referenced in the epigraph at the beginning of this chapter. There is a close relationship between that event and questions about citizenship, cultural identity and national literature, and about what constitutes a Nigerian canon. Reflecting on that last but overarching concern will make it clear that local literary politics result in a local canonical exclusion with enduring transnational effects.

Livinus Nwadiuto Odozor's (Contemporary Nigerian literature 2004) discussion of the 'Nigerian canon' identifies a shared national (even if heterogeneous) "cultural narrative" (59) at its core. Irrespective of cultural differences amongst constituent nation groups and regions he believes that: "the boundaries of the [artificial] state become the

${ }^{73}$ Ofeimun is referring here to the incumbent President of the Association of Nigerian Authors, Olu Obafemi, who as a member of the inaugural advisory board, helped midwife the agreement and terms of the NLNG Literature Prize. For an example of responses to Ofeimun see Nduka Otiono's "Fiction as a Rhetorical Device" (Nigerian Guardian, Dec. 15, 2004). And for other general commentary, see Chiedu Ezeanah and Richard Mammah's "NLNG, ANA and The State of Nigerian Literature" (Nigerian Guardian, Nov. 28, 2004). 
boundaries of Nigerian literature" (62). In other words, even though Nigeria is a politically imagined community (Anderson op cit 1991) it has developed a "narrative idiolect" (61) in its literature, which can be identified as uniquely Nigerian. That idiolect is ironically a result of the complexities involved in a difficult political union and is informed by those "values which [...] are a product of the social, economic and political forces which have formed Nigerian history and culture" (102).

That perennial language debate in African literature, which goes back to the 1960 s, is also central in considerations of questions of a national canon. Joanna Sullivan ("National Literature," 2001) argues that "the issue of language represents, perhaps, the most salient and distressing impediment hindering the definition of a national literature" (74) in a multi-lingual Nigeria. While - and precisely because - he considers works produced either in indigenous languages or (and particularly) in English as belonging to a Nigerian canon, Odozor however discountenances "post-structuralist obsessions" (op cit 63) aimed at cancelling the category of nation in literary matters due to the globalisation of English. He considers such efforts as a universalising, suspicious gambit, which seeks "the obliteration of third world national narratives and the appropriation of these narratives in the course of a post-industrial quest for a global, undifferentiated and guiltfree discourse" (48).

Odozor's rejection of a tendency towards hyperglobalisation (Held et al, Global Transformations 1999: $3 \mathrm{ff}$ ) in local canon formation is ideologically in consonance with arguments for a multilingual, all-embracing view or representation of Nigerian national culture (Sullivan op cit 74ff). Clearly both Sullivan and Odozor do not consider a linguistic criterion, particularly English, alone as sufficient for a work's inclusion within 
the Nigerian canon. This is understandable since "English is but one of the many languages in which Nigerians choose to express themselves" (ibid. 82).

Odozor's 'Nigerian narrative idiolect' is in tandem with Sullivan's reading of Damion Opata's understanding of a Nigerian national literature as one that embraces "the use of national types, myths, themes, and sentiments" ("National Literature" 79). Sullivan critiques Opata as being prescriptive because the latter seems to assume that "such national categories pre-date a national literature" (79). However any delimitation of a Nigerian canon is likely to be prescriptive considering that it is a recent modern development and an unfinished and growing corpus subject to departures and convergences - especially due to exile, diaspora, migration or cosmopolitanism. These categories are socio-political and psychic forces that escape the boundaries of the nation. While the above nationalistic, linguistic and general cultural yardsticks for describing a 'Nigerian' canon are valid, in most cases they become inadequate or problematic when measured against work produced by a third generation Nigerian Diaspora consisting of such writers as Diran Adebayo, Helen Oyeyemi, Jackie Kay, Shade Adeniran, Segun Afolabi, Carole Enahoro or Daniel Evans.

The aforementioned authors are second generation Nigerians (that is, the children of immigrants) living in the Diaspora. Their self-apprehension might not be as complicated as that of the self-exiled Ben Okri of In Arcadia (2002) - an example of the New-Age phase in his writing. Nevertheless their lived experiences and cultural identities are likely to be more complex compared to that of writers who never left Nigeria such as Tricia Nwuabani or migrants such as Chika Unigwe, Chimamanda Ngozi Adichie, or Sefi Attah. A proof of this can be gleaned from a text's 'cultural atmosphere.' Barring self- 
exile, texts whose writers have a relatively intimate identification or ideological affiliation with, and experience of, the postcolony are more likely to represent that space more urgently and with familiarity in subject, tone, local colour, characterisation and in geographical and temporal settings.

For example, even though she lives in the USA as a migrant writer, Sefi Attah's Entwicklungsroman, Everything Good will Come (2008), is the story of a young Yoruba girl, Enitan, growing up in a Nigeria that the writer describes with fondness and a keen familiarity. The author's closeness to that culture is reflected in one of the childhood games which most Nigerian children growing up in the late 1960s and 1970s are familiar with. "At an age when other Nigerian girls were masters at ten-ten, the game in which we stamped our feet in rhythm and tried to outwit partners with sudden knee jerks, my favourite moments were spent sitting on a jetty pretending to fish" (7). Only a writer with a good memory and an intimate knowledge of a Nigerian childhood would remember, or even describe, "ten-ten" with such familiarity. The geographical setting, with the Lagos lagoon as backdrop, consolidates that intimacy. The hallmark of the work's pervasive Nigerian narrative idiolect is the unfolding of events with echoes of the Nigerian Civil war in its narrative background.

The complexity of cultural identity in the temporal and emotional distance of Diaspora is reflected quickly in the themes which engages, for example, Helen Oyeyemi, who was relocated to the UK at the age of four and has never left. Oyeyemi's first two novels grapple with questions of race, immigrant identity in the metropolis, alienation and the borders between sanity and insanity. What might be said to reflect a Nigerian idiolect is her stylistics. The fantasy mode she deploys in Icarus Girl (2005) and in The 
Opposite House (2007) are reminiscent of the animist materialism - rather than magical realism $^{74}$ - of Amos Tutuola and Ben Okri, which goes further back to the esoteric recreation of the Yoruba worldview in D. O. Fagunwa's phantasmagoric Yoruba language novels. In other words, stylistic allusion is the major signal of a Nigerian idiolect in Oyeyemi, apart from occasional deployment of Yoruba names for characters such as Kayode - in Opposite House. She also evokes diasporic versions of (rather than) continental Yoruba religious mythology. In her hands the Yoruba goddess of the sea, Yemoja, becomes the Diasporic Cuban version Yemaja, of whom the Cuban émigré protagonist of similar name, Yemaya Saramagua, is an incarnation. Most of her characters are, like herself, diasporic cosmopolitans. To underscore degrees of cultural self-identification based on emotional closeness to, or distance from, the postcolony one could compare a migrant and at the same time cosmopolitan Teju Cole to a distant and disaporic Oyeyemi.

A reading of Cole's two novels so far, Everyday is for the Thief (2007) and Open City (2011), against Oyeyemi's diasporic thematic preoccupations and cosmopolitan narrative mise en scène will establish the dynamic relationship between authorial global citizenship, cultural identity and the need for an open-ended Nigerian canon. Born in the USA in $1975^{75}$, Cole was immediately removed to Nigeria as a child. He grew up in Lagos and lived there till the age of seventeen before retuning to America. His first work, Everyday is for the Thief is a pseudo-autobiographical return narrative - a nostalgic account of the challenges of life in a chaotic and corrupt Lagos, which the nameless

\footnotetext{
${ }^{74}$ Despite some critics' and commentators' tendency to conflate animist materialism with magical realism, Harry Garuba's seminal essay, "Explorations in Animist Materialism" (2003) on the subject has made the distinction clear. 'Animist realism' is the proper terminology to describe texts whose extra-worldly scenes, events, characters are rooted in an esoteric African cosmogony, which is traditionally animist.

${ }^{75}$ see author website at <http://www.tejucole.com/about-2/> Accessed 22 January, 2013.
} 
protagonist - who is apparently the author's alter ego - has to rediscover after many years of absence. This is a protagonist who returns to familiar and yet strange terrain, smells and scenes, and to old but distant acquaintances. However the illusion of 'homecoming' is broken for the protagonist when he is (mis)recognised as an outsider due to his, perhaps, New York inflected accent, in a Tejuosho market scene. His proud sense of belonging and cultural identity is jarred:

[w]hen I start speaking Yoruba, the man I've been haggling with over a carved mask laughs nervously. 'Ah, Oga, he says, I didn't know you knew the language, I took you for an Oyinbo or an Ibo man!' I'm irritated. What subtle flaws of dress or body language, have again, given me away. This kind of thing didn't happen when I lived here" (48)

It can be safely assumed that Cole, like his alter ego, identifies as Yoruba and as Nigerian. The title of the work itself is a translation of a common Yoruba maxim: "Ojo gbogbo'n t'ole." The author's 'note' at the beginning of the work is self-conscious: "The unnamed narrator of the story is similar to me in certain ways, and different in other ways." The mimetic distance sought in that statement is undermined and rendered ironic in an obvious manner by the concluding and juxtaposed disclaimer: "But he and I are not the same person."

Cole's arriviste protagonist practically apologises for being a migrant in his selfconsciously Nigerian, and indeed rather 'Lagosian,' narrative idiolect, emphasised by a heavy sprinkling of local colour - Yoruba character names, detailed description of Lagos streets with their appropriate names and, the depiction of typical Nigerian official chaos and ineptitude at the Lagos "Consulate," (1) rather than 'passport office,' where he 
sought to renew an expiring Nigerian passport. The work successfully captures the usual hustle and bustle of that maddening postcolonial city. This realist, 'documentary' approach is embellished with a rather avant-garde style for a novel - the image of a typical Lagos building as frontispiece, and the interspersing of the text with photographs of local scenes, figures or objects throughout the chapters or pages. In short, Everyday is for a Thief, in its realism, announces itself as a Nigerian novel written by a migrant writer, who seems to insist that he belongs, that he is not simply just a member of a New York Diaspora. Cole's courting of the postcolony is sustained in Open City but in a relatively subtle and complex fashion.

Although Open City is much more cosmopolitan in characterisation, setting, tone and general ambience than Everyday is for the Thief, it also clearly escapes the aesthetic and moral distance from the postcolony typical of distinctively disaporic writing like that of Oyeyemi. Cole's protagonist, Julius, a seasoned New Yorker, traverses the city in search of self, solitude and companionship. Although the novel begins with an initially nameless protagonist informing us that: "[...] I began to go on evening walks last fall" (3), as he meanders through a very familiar 'open' New York City, his thoughts and his immigrant identity unfold along the way. We get a direct hint of the protagonist's African immigrant roots when he claims, on seeing a satiric movie, The Last King of Scotland, about that African dictator, that "I knew Idi Amin well [...] because he'd been an indelible part of my childhood mythology" (29). He muses on Yoruba creation myth with familiarity (25) in the same breath as he talks about European music, literature or art. The mise en scene is a rich postcolonial cosmopolitanism. 
Nevertheless and unlike Everyday is for the Thief, which insists on its affinities with the postcolony, Open City celebrates cosmopolitanism. This is emphasised by the surreptitious unveiling of Julius's real identity as he walks a faceless, expansive and anonymous New York peopled with crowds of colourful marathoners from all over the world. That cosmopolitanism is further embellished by an eclectic immigrant characterisation in the person of the elderly Japanese, professor Saito and his nurse, Mary, from St. Lucia; a Liberian ex-convict and a Haitian shoe shiner. His immediate neighbours are also immigrants. Hints about the protagonist's general African immigrant persona finally assumes a solid and specific Nigerian identity through the flashback about his school days in chapter six. In spite of his mixed parentage - half-Nigerian and halfGerman - and his English name, Julius finally identifies as Nigerian. We learn that, "[m]y attending NMS, the Nigerian Military school in Zaria, was my father's idea" (76). Then follows the narration of a typical Nigerian high school experience, replete with Nigerian characters and the usual high school bullies made up of older boys in senior classes.

The import here is that prescriptive and traditional notions about the Nigerian canon based on nationalism ought to embrace the extra-nationalistic. Moreover the question of ancestry or roots, even in the face of adoptive citizenship, migrancy, Diaspora or exile, ought to be germane to formulations about national canons - irrespective of writers' ideological predilections. For example T. S. Eliot's adoption of British citizenship cannot erase the fact of his also having being an American. It is with the foregoing thoughts as background that I will now discuss the recent denationalisation of 
migrant Nigerian writers - due to their dislocation - when it came to competing for a newly established local literary award, the NLNG Literature prize.

\section{The NLNG and Local Literary Politics}

The epigraph at the beginning of this chapter recalls one of many responses to the decision to limit the awarding of a newly endowed literature prize to only Nigerian writers who live in that country. The Nigerian Liquefied Natural Gas Cooperation (NLNG) instituted the Nigerian prize in Science and Literature respectively on the $9^{\text {th }}$ of February 2004. Each award was worth a staggering 20,000 American dollars ${ }^{76}$. In officially registering the literature section of the prize, what had been, during conception, the 'NLNG Literature Prize' suddenly metamorphosed into "The 'Nigerian' Literature Prize," even while it incorporated a residency clause that excluded a very active and sizeable community of migrant Nigerian writers. This resulted in a controversy in national and transnational public spheres ${ }^{77}$ spearheaded by the Nigerian second generation poet and gadfly, Odia Ofeimun. In a derisive tone and temper, he couched the debate in tropes of drilling - this is especially significant in an oil-rich but ironically impoverished country. Writers were 'onshore' or 'offshore,' each term describing those who were on the ground in the country or those who were 'lost at sea' like oilrigs.

At stake in the debate were questions of institutional validation, literary consecration and promotion, dissemination and that local and global visibility and canonisation consequent upon these. This was why the NLNG's initial exclusionary

\footnotetext{
${ }^{76}$ That amount has since been increased to 50,000 dollars. The 2008 prize money, which went to Kaine Agari for her debut novel, Yellow-yellow, was 50,000 dollars. The prize money is now at the very generous amount of 100,000 dollars.

${ }^{77}$ This controversy - which began with Ofeimun's critique in the Nigerian news media and the responses it drew - spread to artist-cum-advocacy groups such as the Committee for Relevant Arts, CORA; to writers' groups such as the Association of Nigerian Authors (ANA) at the national and state levels in Nigeria; to online articles, blogs, and discussion groups like, Wordsbody, Krazitivity and JosAna.
} 
clause, apart from its local literary self-deprecation, marginalised Nigerian writing on a transnational scale, especially in view of a more complex metropolitan exclusion of the same corpus that has been the subject of this dissertation. The complication of a larger global limitation on Nigerian writing was very significant if we consider that the NLNG Literature Prize is the only first substantial material reward for literary creativity towards the encouragement of dedicated literary production ${ }^{78}$ and has potential for boosting Nigerian writing's global cultural capital.

At the time the NLNG prize was initiated, there already existed a string of largely honorific Association of Nigerian Authors annual literary prizes. These are, on the one hand, stipends sponsored by private businesses like Cadbury or Spectrum Books for publicity but on the other, such prizes defeat literary consecration due to a lowering of standards in the process of their being awarded. That is exemplified in the fact that, in a bid to make up for the lack of literary patronage from the State and for the difficulties experienced by new writers in finding publication outlets (Garuba 1988 op cit xv), manuscripts were sometimes awarded the ANA prizes. This contradicts global standards where prize entries must be professionally published books, which have passed through rigorous editorial vetting and peer review. The one prize which met all the vetting standards - the All Africa Christopher Okigbo Prize for Literature - was defunct. Generally, the local Nigerian literary prize does not fulfil the usual goals of global visibility through active media promotions of winners and remains a local phenomenon. Those facts made the initial exclusionary clause of a potentially more media-savvy

\footnotetext{
${ }^{78}$ Ofeimun notes this in his essay "Against a Ghetto Prize for Writers (Nigerian Guardian, May 10, 2004). According to him: "Before the announcement of the NLNG Prize, the literary prizes awarded, mainly by the Association of Nigerian Authors, were generally less than pocket monies for the winning writers. The prizes were also dogged by what writers like to call the 'abiku' syndrome, arising from poor funding that created fears ... whether any prize would last."
} 
NLNG literary institution more problematic since the prize is a first real opportunity for local literary projection of Nigerian literature onto the global. That is in terms of the NLNG's astronomical monetary value (at its current 100, 000 dollars) and its powerful organisational structure and media reach.

However, the inaugural advisory board ${ }^{79}$ of the NLNG award, through its erstwhile promotion of an identity politics, ironically managed to localise and thereby 'short-change' an otherwise generous and potentially internationally consecrating and allembracing prize. This is why Ofeimun refered to the award as a "ghetto prize" 80 ("Against a Ghetto Prize" Nigerian Guardian, May 10, 2004) which seeks to "fractionise the soul of Nigerian Literature" ("Do not Ban" Nigerian Guardian, May 13, 2004: 1) by pitting Nigerian writers at home against those abroad. Ofeimun hints at a rationale of corruption behind NLNG's politics.

Underlying the Nigerian literary establishment's obsession with location, translocation or 'dislocation,' and its legitimising of home or delegitimation of exile, is a political instinct and socio-economic calculations which invariably recalls what, in describing modern African statecraft, Bayart (1993) refers to as a "politics of the belly" ( $x, 242 \mathrm{ff}$ ) - in this case the onshore (as distinct from the offshore) writer's belly ${ }^{81}$ rather

\footnotetext{
${ }^{79}$ This initial board consisted, amongst others, of some eminent scholars and respected writers, amongst others, like professors Femi Osofisan, Ayo Banjo, Dan Izevbaye, Theo Vincent, Charles Nnolim; the publisher Joop Berkhout, and Association of Nigerian Author's (ANA) high officials in - surprisingly 'unofficial' capacities. Ofeimun queries the houseboy role of ANA in this panel as represented by Nduka Otiono and Olu Obefemi, General Secretary and President respectively (see "The NLNG Literature Prize Controversy," Nigerian Guardian, Nov 28, 2004). The process was so politicized and fraught with infighting that the NLNG organizers eventually marginalized some of these people, including the 'unofficial' representatives of the writers' body.

${ }^{80} \mathrm{He}$ argues that the localization of the Nigerian Prize in Science or Literature is, ironically, an obstacle to its targeted excellence.

${ }^{81}$ Ofeimun insinuates as much without really stating it in his "The NLNG Literature Prize Controversy." op. cit.). In a response to Prof. Femi Osofisan's having been reported to have seen the Gas company's actions - especially its hijack of a 'Nigerian Literature Prize' - as being in order, Ofeimun queries and comments: "Is it for crumbs that we are now amoral? I ask this question because a member of the NLNG
} 
than the politician's. A politics of the belly is one characterized by personal selfenrichment and a brazen looting and sharing of government treasury and public funds ${ }^{82}$. The (im)moral compass of the NLNG's exclusionary clause is insinuated in Ofeimun's public interventions and re-echoed more specifically by other commentators.

Obi Nwakanma ("What is Nigerian Literature," The Vanguard 2005) for example, suggests that the prize is a political diversion. He highlights the dubious business connection between the gas company and a discredited Halliburton in the USA, and links the former to a long history of environmental pollution in the Niger delta, and to the Nigerian Government's 1995 judicial murder of environmental rights activist and writer, Ken Saro-Wiwa. All of those points buttress the fact that the prize is meant to be a local affair and a means for 'pacifying' one of the most vociferous groups in society - writers. "It seemed that the managers of the NLNG quickly enacted [sic] an orchestra to deflect questions from itself by announcing 'mouth[-]watering' prizes to the most vocal and certainly the most impoverished of the Nigerian elite: the intellectuals, especially the writers" (ibid. 4; my emphasis).

Literature Panel, Professor Femi Osofisan, has been quoted to the effect that there is nothing the matter with the Gas Company registering The Nigerian Prize for Literature. To him it is just a matter of one company outsmarting others by jumping first. Does this say that we are all now mere handmaidens of a smart multinational which can choose to mis-define and misdirect our literature if it pleases? This is what I call selling national patrimony for a mess of pottage" (4).

${ }^{82}$ That is the case, even if Bayart, in an effort at political correctness, tries to normalise it as an "African Way of Politics" (242), or simplify it as a historical symptom of postcoloniality. Widespread as this practice is in Africa south of the Sahara, Nigeria has a particularly brazen variation of it and has turned corruption into a morbid art form. An example is the scandalous case of official corruption in high places between the contract-seeking multinational, Halliburton, and several Nigerian past presidents over years.

Bayart provides copious examples of popular discourse, usually couched in euphemistic terms, which refers to the phenomenon of official bribery and corruption all over the continent - in Nigeria it is euphemistically referred to as the sharing of the 'national cake.' (See http://www.guardian.co.uk/world/2010/dec/02/dickcheney-halliburton-nigeria-corruption-charges> and <http://blogs.wsj.com/corruptioncurrents $/ 2010 / 12 / 21 /$ halliburton-says-it-will-pay-35-million-to-settle-nigeria-bribery-charges $/>$. Accessed June 20, 2010). 
Nwakanma echoes that urgent political dimension which was first insinuated in, and emphasised by, Ofeimun - reaching a crescendo in the latter's "Do not Ban Writers Abroad" (op. cit.) - a year and several essays earlier. Moreover, even if the literary establishment appears to be engaged in an exercise of simple literary patronage, there is more at stake. Apart from moral queries, the important question of literary value and what constitutes a Nigerian canon is at the centre of the NLNG debate. Canon-formation, the NLNG's unwitting province, is central to the vigour of any national literature. "The Literature Prize especially damages its own credence because it underestimates the nature of prizes as the basis of canon formation" (ibid. 5).

A casual but observant visitor to Nigeria today will quickly find answers to the official need for the corrupting of a home grown intellectual class by the political one. It bears repeating that this is done through a government proxy - the NLNG, overly privileged and powerful as it is in its multinational affiliations and dominance over an oilbased economy. As part of my research, I had to visit Nigeria after an absence of some fifteen years to re-familiarise myself with the 'field.' Many years of reading about urban decay and failure in the African socious from exile, and previous familiarity with a benign form of it, did not quite prepare me for the Nigerian example of an almost

\footnotetext{
${ }^{83}$ Abiola Irele in "The African Imagination" (Research in African Literatures, Vol. 21.1 (1990): 49-67) has argued against the description 'national literature' where any African writing is concerned since such writing is not readily accessible to everyone within the nation through one single universal 'indigenous' language, especially in the background of the perennial language debate in Africanist discourse going back to the 1960s and with Obi Wali's seminal essay, "The Dead End of African Literature" (Transition: 1963) and as recently as Ngugi Wa Thiongo's "Europhonism" (2000) or Pius Adesnmi's response to it in "How Not to Talk of the Future of African Literature" (2002). But it can be argued that since European languages have become the adopted official languages and the language of modern global African writing, the literatures produced in them may be termed national literatures. Nevertheless this is not to be confused with Frederic Jameson's polemical description of all 'Third World' Literature as "national allegories." Aijaz Ahmad has sufficiently critiqued Jameson's position.
} 
continent-wide retrogression, and a progressive socio-political and economic chaos. First experiences are, of course, impressionistic, visual and (un)scenic.

Public facilities, infrastructure and institutions are broken-down and dilapidated. This is attended by an equally rapid collapse of utility services; basic amenities such as regular water or power supply are erratic in urban centres and non-existent in the rural areas. During three weeks of stay in Lagos, an important economic heart of the country, there was electric power supply for only about four or six hours. As such citizens have to provide such basic amenities for themselves through their own ingenuity. Personal power generating plants proliferate for business and private use; there is noise pollution thereby - throughout the night especially. This is attended, of course, by the resultant air pollution from the carbon mono-oxide produced by these electric power generators and lead to health hazards.

On closer inspection of this chaotic situation, I discover that those services normally provided by any fiscally responsible government are either non-existent or have been largely privatised in an unofficial sense. These include, apart from electricity, primary, secondary and tertiary education, the airline industry, effective security, even banking - to some extent: the black or 'parallel' money market competes successfully with the official one ${ }^{84}$.

The economy, since the 1970s oil-boom, has not been diversified and is more oil dependent than ever. Nevertheless the country cannot refine its own oil but relies heavily on external labour and actually imports processed petroleum for local consumption. There is hardly any production of original goods; most consumer products are imported.

\footnotetext{
${ }^{84}$ In a system based on official looting, of course, it is necessary to have an auxiliary financial operation on the streets, useful for money laundering.
} 
The result of this, coupled with an intolerable level of corruption in government, is a high inflation and the destruction of any semblance of a middle class. As a matter of fact there is no class structure to be spoken of beyond 'the haves' and 'the have-nots' - that is, the 'bourgeoisie' and the 'proletariat' - according to Karl Marx's formulation in The Communist Manifesto $(1967: 131)^{85}$. The intellectual class ${ }^{86}$ in Nigeria, as represented by the onshore writer, belongs to the latter group as Nwakanma suggests above and has been unwittingly co-opted into the corrupt postcolonial order of things. It is worth dwelling on that postcolonial arrangement for a while, the better to anchor cultural production within a framework of continental socio-political and economic forces.

In his seminal essay, "Colonialism and the Two Publics in Africa" (1975) Peter Ekeh rightly locates contemporary African political praxis, with its contradictions, challenges and imperfections, within an immediate colonial root and rot. The link or symbiosis between colonial and postcolonial administrative structures is common knowledge. It has led to that dysfunction in the African State, which is the subject of

\footnotetext{
${ }^{85}$ According to Marx, "[b]y bourgeoisie is meant the class of modern capitalists, owners of the means of social production and employers of wage labour" (Communist Manifesto 1967: 131). The Nigerian bourgeoisie, at variance with that classic Marxist conception of that class, do not produce anything in any direct sense - even if they do own capital. Such capital is appropriated from public funds and then invested in "secondary production," that is the production of goods or services that are a copy from elsewhere rather than anything innovative. Marxist formulations of labour, class and capital need a reworking in the African case. Nevertheless the idea of the proletariat as "the class of modern wage labourers, who having no means of production of their own, are reduced to selling their labour power in order to live" (ibid. 131) would fit the Nigerian situation but with the exception that an adoption of this Marxist concept needs a reformulation. Labour can be sold only if there is a market for it or if the economy is large enough to make demand for labour universal. The army of beggars, urchins, and jobless all over the country either do not have skills to sell or their skills are not needed. Moreover to refer to writers as part of the 'proletariat' might seem a bit disingenuous from a traditional Marxist perspective. Nevertheless the intellectual class in the West cannot be compared to that in the developing world. Writers usually have other jobs and are never full time writers. As such they belong to the army of the downtrodden masses. They work of course as organic intellectuals or as professors at universities.

${ }^{86}$ This class which would normally be referred to as elites in other social formations, cannot be regarded as elite, according to Peter Ekeh (1975: 94), in the Nigerian or in most African social situations since these kinds of 'elite' groups do not form theirs ideas free of ideology. This due to direct coercion (as in censorship) by the "repressive state apparatus" or by the "ideological state apparatus," that is, religion, law, etc (Althuser, Lenin and Philosophy 1971: 142ff).
} 
other studies such as that mentioned earlier - Jean-Franscois Bayart's The State in Africa: Politics of the Belly (op. cit.) - or Patrick Chabal and Jean Pascal Daloz's Africa Works: Disorder as Political Instrument (1999) ${ }^{87}$. Ekeh locates the perplexity of the African State as being due to its personality split between two publics - the primordial and the civic respectively. The former arises from traditional structures and ties while the latter is an inheritance from colonial "civil structures: the military, the civil service, police, etc" (op cit 92). These blurring distinction between the private and the public spheres is further complicated by the moral dissonance of these publics in their politics, and relation to the private sphere: "The primordial public is moral and operates on the same moral imperatives as the private realm.[...] The civic public in Africa is amoral and lacks the generalized moral imperatives operative in the private realm and in the primordial public" (92; original emphasis). The systemic failure in African politics is then a result of "[t]he dialectical relationship between the two publics" (93). It can be argued that the moral primordial public has collapsed into its more cancerous twin, the amoral civic public, which has become a kind of "rapidly expanding public sphere that [is] simultaneously privatized by kickbacks and subsidies" (Apter, "Oil Money and Spectacle in Nigeria" 1996: 453; my emphasis). The expression, 'rapidly expanding' is significant because its effect is to constrict the traditional primordial public, even with its filiations and affiliations, to a point of disappearance. At the same time, all civic structures, institutions, duties, responsibilities and indeed the social body itself, is sucked into a

\footnotetext{
${ }^{87}$ Due to an exaggerated overcompensation for Eurocentrism in past studies of Africa, these critics, writing as late as the 1990s after Ekeh, normalised failure as co-terminus with the African state rather than being the symptom of a historical complex of slavery and colonialism complicated by present-day comprador leadership. They fall into the trap of that "cultural relativism" and "African exceptionalism" which Jemima Pierre ("The Race for/of Africa" in Zeleza, 2006: 44ff) in, explains as still being a strong essentialising impulse in Ethnography and anthropological accounts about Africa. She zeroes in particularly on Michael Apter's otherwise analytically factual but anthropologically othering analysis of Nigeria's cultural spectacle, Festac 77.
} 
corrupt public sphere, which is amorphous, without boundaries and invisible because it has no civic responsibilities, nor any relationship to an already amoral civic public, which it completely annihilates. In the social imaginary of oil capitalism there is of course the semblance of a civic public but in the real it is an illusion. The result is systemic chaos economic and fiscal, political and governmental, civic and structural, environmental, cultural, moral, spiritual and existential.

In such a socio-political and economic dispensation the ideological state apparatus (Althusser op cit 1971) commodifies and hijacks cultural production as a tool for the legitimation of this postcolonial (dis)order through its "culture-brokers" (Apter op cit 450) - for example, the NLNG. In other words literary form is given a value and converted into oil-money form while, by the same token, the authorities seem to be 'promoting' literature ${ }^{88}$. Literary opposition is staunched by petro-dollar. A dissimulating intellectual class becomes quiescent. The NLNG, due to its vast resources from the proceeds of the oil industry and in spite of itself, suddenly becomes a powerful local canon-forming institution even though that company is not a literary organisation.

Although the NLNG was forced by negative criticism to rescind its exclusionary clause for the literature prize, it can be argued that it still merely promotes a literature of the (post)colonial status-quo. Ekeh (op. cit.) notes that the transition from colonialism to independence and post-coloniality necessarily involved the replacing of a conquering foreign colonial bourgeoisie with an indigenous African one. The latter was legitimised initially through anti-colonial ideologies, which supplanted colonial ideologies (93ff). It is significant that the same structures of feeling inform the colonial and the contemporary

\footnotetext{
${ }^{88}$ The lie is given to that impression by the unchecked creation of a 'censorship board' by Nigeria's Northern states, which function within the legal principles of the Islamic Sharia in the same one country. This is a symptom of the schizophrenia of oil capitalism.
} 
postcolonial. African governmentality is in-dependence to colonial rule and ruse, such that the former is a parody of the latter. Chief amongst the ruses deployed by foreign rule was colonial pacification through ideology. It worked on the psyche rather than the colonial body, which then policed itself ${ }^{89}$. The NLNG has incorporated the intelligentsia into the primordial public, of which the latter is a core member, by way of a postcolonial pacification through the ideology $y^{90}$ of cultural promotion.

As mentioned above the NLNG's exiling of offshore Nigerian writers, naturally resulted in queries about the existence of a local canonical exclusion, which privileged the writer's physical presence in Nigeria, beyond questions of literary value, in deciding which writers should belong to the national canon. The magic realist quality that identity politics can assume in the postcolony is exemplified in an event during the fierce political competition of the Second Republic in the late 1970s. Abdurrahman Shugaba Darman of the Great Nigeria People Party (GNDPP) was a charismatic Northern political figure and therefore a threat to the ruling National Party of Nigeria (NPN) government (Fasua "How Shugaba was deported" Daily Mirror, January 13, 2013) led by Shehu Shagari. Shugaba, as he is popularly known, was declared a foreigner by the ruling government, physically removed from his house and deported to the neighbouring country of Chad republic "on January 24 1980" (ibid.).

Another aspect of NLNG's local literary politics is that the lowering of standards and suspected lack of transparency in the awarding of the older ANA Prizes was carried

\footnotetext{
${ }^{89}$ The effect of this self-policing is similar to that which obtains within the original model prison where inmates self-police ceaselessly due to the all-seeing eye of the Panopticon - Jeremy Bentham's architectural surveillance machine, which is the basis of Michel Foucault's theorising of the relationship between power, penology and self-coercion in Discipline and Punish: The Birth of the Prison (1975).

${ }^{90}$ Ideology here is used in Peter Ekeh's sense in his essay "Colonialism and Two publics" (1975) as falsification of intent and a desire to hide the truth.
} 
into the NLNG awards. In the aftermath of the Ogoni problem and the difficult relationship between the entire Niger Delta region and Nigerian Oil industry (Na'Allah Ogoni's Agonies 1998), of which NLNG is a unit, a writer from that part of the country was destined to win the award. In other words, the exclusionary clause against migrant writers is further sealed through a domestication of that prize as form of national Affirmative Action. This explains why Kaine Agary, who is an indigene of the Niger Delta region, won in 2008 (Akubuiro "NLNG Prize" The Sun, October 15, 2011).

Yellow Yellow (2006), Agary's winning novel, is a story set partly in the oilpolluted backwaters of the Niger Delta. "During my second to last year in secondary school, one of the crude oil pipes that ran through my village broke and spilled oil over several hectares of land, my mother's farm included" (3). In that emotive fashion Agary's sets the geo-political tone of a story about a young woman, Yellow Yellow, who moves from her village to the city of Port Harcourt in search of self and, the Golden Fleece. The language of the novel announces it as popular fiction, a genre sufficient in itself but not usually the object of consecration with expensive literary awards: "my second to last year in secondary school" (3) is just one example of the awkward colloquial writing. Another is: “I wish I could talk to Lolo, but she was going through her own issues with Kamal (160). Moreover, the novel is also self-published ${ }^{91}$ and as such is technicaly deficient - poor print and binding quality, for example.

In awarding Yellow Yellow the Nigerian Literature Prize the usual literary global requirements of professional peer reviewed and published work was short-circuited by the politics of oil. It can be argued that the work's 'consecration' was a local variation of an Affirmative Action and an acknowledgment of its content or message - its theme of

\footnotetext{
${ }^{91}$ The author told me this herself during my field trip to Nigeria.
} 
environmental pollution - rather than its literary quality. While it is itself a politicising gambit, NLNG's exclusionary clause further enabled more ideological limitations of the consecrating power of the prize. Limiting clauses would be irrelevant if emphasis were to be placed back on literary quality, subjective as even that is. Focusing on literary quality would render a writer's migrant condition or local habitation irrelevant, as it is the case now with the eventual withdrawal of the limiting clause.

Moreover, it should be noted that onshore location - as the singular case of Helon Habila's success and eventual translocation reflects - does not necessarily seal the homebased writer's fate one way or the other. Nor is offshore domicile a guarantee of success if we are to consider the myriad of those whose voices have become disembodied and 'disclocated' in exile. Fledgling poets such as Denrele Ogunwa or Funmi Adewole, who both relocated to the UK in the late 1980 s and early 1990 s, have practically stopped writing. Sola Osofisan, a very promising member of the third generation, has not realised his full potential since he relocated to the USA in the 1990s. He won both the Association of Nigerian Authors's poetry and prose prizes in the same year - 1990 - for Darksongs (1991) and The Living and the Dead (1991) respectively. Sanya Osha's 1992 ANA award-winning novel manuscript, with the ironic title, Serving Time, has never been published, even though he now lives in South Africa. And if it has been brought out at all it must have been issued as Naked Light and Blind Eye only as recently as 2010. Nor has Biyi-Bandele-Thomas, although relatively prolific in England, achieved the kind of international literary respectability he justly deserves.

In the light of the above, the NLNG's initial exiling of migrant Nigerian writers defeated what ought to be the goal of the prize, that is, the local and global promotion of 
Nigerian writing. Although this residency clause as a limiting criterion has been removed since $2010^{92}$ after the barrage of criticism against it as discussed above, it can still be said that the Nigerian Literature Prize, rather than promoting Nigerian writing to a global audience, is still a local affair. This is because, due to the NLNG's institutional (self)limitations and subordination to similar metropolitan structures, the prize does not yet translate into global visibility for a winning entry.

In the new post-residency-clause dispensation where a migrant writer like Chika Unigwe wins the Nigerian Literature prize in 2012, it can be argued that there is not much value added to the work itself. Unigwe's On Black Sister Street, published in London in 2009, already had global visibility before being entered for the NLNG prize in 2012. This novel then probably does more in promoting the prize than the other way around. It is an ironic situation where participation by formerly excluded migrant writers already acclaimed in the metropolis - say Teju Cole, or Chris Abani, apart from Unigwe - might end up raising the value of the NLNG Prize itself, consecrating it and imbuing it with global relevance.

\section{The Retrieval Canon}

The consequence of a nation-bound canon, local literary politics and a lowering of literary awards standards is the proliferation of what I refer to as a 'retrieval canon.' A retrieval cannon exists when literary value is reduced to the lowest common denominator, the better to indiscriminately consider all written material as 'literary.' Although it can be argued that $18^{\text {th }}$ century England had this all-inclusive approach to what literature is before the romantic period (Eagleton Literary Theory 1983), nevertheless we are in a

\footnotetext{
${ }^{92}$ See interview with the Public Relations Manager of the NLNG, Ifeanyi Mbanefo at $<$ http://www.ynaija.com/from-the-magazine-our-agenda-is-a-better-nigeria-ifeanyi-mbanefo-nlngcommunication-pr-boss/>. Accessed February 3, 2013.
} 
different age. In as much as literary value will always be ideological to varying degrees (Eagleton ibid. 22; Herrnstein-Smith "Contingencies of Value" 1983), there are still some objective standards by which what is literary can be separated from the mundane or ordinary. One such criterion is elevated language as opposed to the banal and the colloquial or trite - all within specific contexts, of course. The colloquial, within limits, would be admissible in characterisation - to give an example.

A retrieval canon is built when obvious and globally accepted standards of literary quality are removed and all works are 'retrieved' as literary. This nation-bound and 'retrieval' approach to the conception of a Nigerian canon is rooted in the sociological, anthropological and literary-historiographical approach of foundational Western critics of African literature. Critics like Bernth Lindfors (1982, 1995) James Booth (1981), Albert Gerard (European Language Writing in Sub-Saharan Africa 1986), Charles Larson (Emergence of African Fiction 1972; Onitsha Market Pamphlets 1947), Janheinz Jahn (Neo-African Literature 1968) and latterly, Wendy Griswold (2000) all have a sociological understanding of an African literary canon. They approach it as a collocation of the aggregate modern African literary production in Europhone languages. This is clearly due to the fact that African literature as an object is a relatively new phenomenon that needs to be, well, retrieved - tabulated, counted and classified.

The result of a socio-historical and ethnographic conception of a retrieval canon is that it posits an all-inclusive, non-discriminating understanding of African writing. For example, Griswold's discussions of Nigerian literature is invariably a matter-of-fact sociology of the literary field, while Lindfors' in Early Nigerian Literature (1982:5) and 
Long Drums and Canon (1995: 50, 54ff, 58, 71), proceeds by tabulating publishing statistics as a fact of total or aggregate literary production between particular periods.

The above critics treat the popular as part of the general sociology of literary production. Only Emmanuel Obiechina, in the introduction to his groundbreaking Onitsha Market Literature (1975), establishes an unequivocal distinction between the popular and the literary. He declares that he is engaging pulp material or popular literature as a form legitimate in itself. Even some contemporary continental African and Africanist critics located in the Western academy employ the same 'sociological list' paradigm when discussing the African canon.

The retrieval canon in its ethnographic and sociological approach was most likely encouraged by the work of foundational Western cultural anthropologists such as Placide Tempels, Marcel Griaule, Alexis Kagame or Leo Frobenius (see Irele African Imagination, 2001:3). Naturally an anthropological or ethnographic view of African literature would seek to capture an 'African essence.' This is similar to what Edward Blyden, in a different pan-Africanist context, has famously described as the 'African personality' (see July Modern African thought 208ff). That is, an African 'essence' or a collective vision as refracted through literature - or through art in other instances - so that "it may be possible to speak of one African culture" (Bhola, "Literacy in SubSaharan Africa" 1990:6) irrespective of its being also variegated. Abiola Irele refers to a similar essence when discussing the black experience as understood through literature. His is an idea of a universal African 'tonality,' which he conceptualises as 'African imagination,' evident in the experiences captured in African literary works or in black literature generally. In his words: "African imagination [is] to be taken $[\ldots]$ as referring 
to a conjunction of impulses that have been given a unified expression in a body of literary texts. From these impulses, grounded both in common experience and in common cultural references, Black texts have come to assume a particular significance [...]" (4).

Beyond its foundational historical beginnings the retrieval canon was entrenched as a critical methodology - in Nigeria at least, and most certainly across the continent due to the transnational literary establishment's glorification of Africa's arrival into Euromodernity as exemplified in the case of Amos Tutuola above. Beginning in the 1980s the retrieval mentality took permanent root and became normalized due to the economic and existential difficulties of a post oil boom Nigerian nation, and its attendant unfavourable material condition of cultural production.

It bears repeating that the beginnings of a contemporary Nigerian retrieval canon cannot be divorced from the economic collapse of the 1980s. The social production of African literature - like any other literature - has the political, economic, existential, psychic and ideological as catalysing forces ("Crises of Consciousness" 1974; Bearing Witness 2000; Bernth Lindfors 1982; Field of Cultural Production 1993). In the Nigerian instance the overriding catalyst around which other factors cohered towards restraining literary production was the oil bust of that period (Watts "From Boom to Bust" 1984), the resulting IMF-inspired Structural Adjustment Program, related local currency devaluation and the progressive economic depression attending them. In Bearing Witness Wendy Griswold details the debilitating impact of Nigeria 1980s economic gloom on publishing infrastructure (2000: $37,69 \mathrm{ff})$, the decline in quality of production, especially as exacerbated by the proliferation of the small and vanity press, which resorted to the 'printing' of popular literature and cheap romance novels for survival. It is within that 
Unterhaltungsliteratur complex, which echoes an antecedent Onitsha market 'literature' and was bolstered by an eroded publishing infrastructure, that the retrieval canon has its immediate contemporary foundation. Griswold captures that economic environment succinctly and is worth quoting at length:

Nigerian Publishing had always been beset with problems obtaining material ink, film, chemicals, plates, and most of all paper - as a result of the high customs duties on imports and scarce and foreign exchange. With only three paper mills, newsprint was both insufficient and expensive. And the expenses involved in importing foreign books added to the costs incurred by local booksellers, schools, and libraries. [...] With the end of the oil boom and the economic collapse that followed, capped by the Structural Adjustment Programme (SAP) of 1986 and the second Tier Foreign Exchange Market (SFEM) that devalued the naira, the Nigerian market for books, especially trade fiction, evaporated. (Bearing Witness 69)

The above then were the material conditions of literary production into which third generation writers were thrust in the 1980s (Larson Ordeal of the African Writer 1980).

Publishing standards suffered in the kind of socio-economic and existential context detailed above even as local subsidiaries of withdrawing multi-nationals became nationalised, while some reputable small presses and a myriad of vanity presses proliferated (Bearing Witness 70) and have since mushroomed. I posit that the foregoing scenarios could only further aid the exclusion of Nigerian literature in the metropolis.

One of the general ways in which the local retrieval canon bolsters global literary exclusion is that it produces an excess of creative writing in the popular mode to such an 
extent that works of value disappear amongst the pile as 'hidden texts' due to the disabling and 'invisible context' of an avalanche of 'vernacular literature' - as distinct from literature "in the vernacular ${ }^{93}$. In such a case the negative literary provenance of a retrieval cannon would most likely discourage local or metropolitan literary agents, publishers or publishers' representative. It complicates canonical exclusion by distancing serious metropolitan literary/scholarly or research interests (except for sociological purposes only). ${ }^{94}$ Transnational critical efforts are then limited to third generation migrant texts that already circulate in Euro-American publics and academic circuits.

In concrete terms, invisible contexts may be conceptualised as those disarticulating local material conditions of production and dissemination - transhistorical, technical-editorial, technological, cultural, institutional, genre-specific, conceptual and paradigmatic (i.e. as represented in the retrieval canon itself) - which directly or indirectly contribute to the global marginalisation of African texts by rendering them 'invisible' or 'hidden.' Specifically, such material processes might include, but are not limited to, publication by virtually unknown local or global small or vanity presses, poor editorial quality, questions of a literary or merely verbal language, poor press work and packaging, ineffective dissemination and relative exclusion from metropolitan academic or readers' club lists ${ }^{95}$, lack of local consecrating mechanisms with a global reach, the ironically double-edged alienating effect of metropolitan prizes

\footnotetext{
${ }^{93}$ For example a work like Ken Saro-Wiwa's Sozaboy is written in a vernacular pidgin English but is not necessarily 'vernacular' in the sense of a 'popular' literature. It is a text, which engages serious social issues in a language that, even if not standard English, is rich and evocative within its own peculiar morphology.

${ }^{94}$ Some examples are works by Bernth Lindfors.

${ }^{95}$ The Western reading club phenomenon has been made important through the Oprah Winfrey Book Club, which by its mere selection of an author's work for public presentation on global television, lends a general public consecration to such works and draws the attention of the academy to them. In an unprecedented example, Winfrey featured the Nigerian third generation writer Uwem Akpan's novel, Say you are one of Them, turning him into a global celebrity overnight.
} 
because of their tokenism, and the lack of global critical reception in peer-reviewed journals for otherwise excellent local publications.

The managing of the margins which global canonical exclusion performs from the centre and at a distance is aided, ironically, in the periphery by the local retrieval canon. While the retrieval canon helps to re-inscribe the margin as symbolising an aesthetic economy of waste (Lincoln 2008) due to its plenitude of apparent pseudo-literature, a parasitical centre nevertheless re-figures, and colonises that abjection (Kristeva Powers of Horror 1982) as literary resource generally. It salvages material of 'readable' or relatively good literary quality, but predominantly of the self-anthropologising kind, for its own self-constitution. This necessitates the complete 'excretion' of other works of equal or greater merit but which do not conform to the centre's ideological requirements that such work 'self-denigrate' - in conforming to accustomed stereotypical, sensational, exotic Western perceptions of Africa.

While the argument that the retrieval canon functions as abjection in relationship to the global canon - which it sustains - has been established, it is useful to note that this abjection is achieved through a trans-historical and complicated manner. External global historical erosions and exigencies - due to the subordination of culture to Culture (Eagleton Idea of Culture 2002, Williams Culture and Society 1958) - resulted in retrieval, in the first instance, in the background of a more immediate perpetuation of that historical lack through a contemporary and local lowering of standards in literary, editorial and technical terms.

That retrogression in standards is heightened by the irony that the historically subordinating centre still has to consecrate a cross-section of the local retrieval canon, 
whose only merit might be their subject matter rather than literary quality. This it does through international literary prizes, which consecration further simulates historical lack because it canonically excludes more than it includes. It consolidates retrieval by perpetuating the anthropological demotic terms of a festishized history through its promotion of mainly self-anthropologising themes in third generation writing. Teju Cole's novel is an excellent example of a third generation literary work, which is totally at variance with a self-anthropologising narrative but still achieves great literary worth. Examples of canonically excluded locally or trans-nationally published works of literary merit are Roots in the Sky (Adesokan, 2004), Invisible Chapters (Nwosu, 2001) War Games (Mbachu 2005), A squatter's Tale (Oguine 2000) and Arrows of Rain (Ndibe 2000). Like Teju Cole's work, the foregoing are not self-anthropologising in any conscious way; unlike Cole's novel, all but two were not published in a literary capital or by a prestigious house like Random.

The above examples of novels confined to the retrieval canon are, of course, not an exhaustive list. Since canonical exclusion involves mainly the novel form, hardly any third generation poetry or drama receives canon-forming attention in the metropolis. This increases the bulk of works of literary value buried within a local or migrant retrieval canon, which of course does not preclude third generation work published in the metropolis - hence a 'migrant' retrieval canon. Vanity presses also do abound in the metropolis. Unoma Azuah's Sky-high Flames (2009), Ubaka Ogbogu's Bread and Blood Tonics (2005) both 'printed' by Publish America, a vanity press in the USA, Nnorom Azuonye's Letter to God and Other Poems (2003), self-published in the UK, are examples of the third generation work in the retrieval mode. 
Apart from genre preferment, place of publication, the institutional position of a publisher in the metropolis and - as such - the effectiveness of its protocols of illumination, also have important ramifications for global canonical inclusion or exclusion. In other words, it is important to emphasise and echo the argument in chapter three that the self-anthropologising subject or ideological mood of a third generation text is not the only determinant of its entrance into the global circulation of world literature. Place of publication - emphasised in the importance Casanova places on literary capitals - is vital in how far a book travels from its point of 'origination.'

The limiting effects of the retrieval canon as previously detailed, which should not be understood in any prescribed order, or which are not necessarily exhaustive and can incorporate any complex of unforeseen restrictions, simply function as a disarticulating matrix. The farther away a work's point of origination is from a 'literary capital' the poorer or non-existent is its representation on global library holdings. It becomes 'hidden' by those disabling invisible contexts of retrieval, 'hidden' and 'invisible' being here understood in literal as well as figurative senses.

The correlation between publication in literary capitals and the distance travelled by a book can be empirically ascertained. But first, it is common knowledge that there are different kinds of libraries - research libraries, public libraries, subscriptions libraries and so on. These are the public and market consciousness of the global literary canon. That such depositories are crucial to dissemination is underscored by their globalisation through new electronic media in the form of virtual data banks accessible from any point on the planet with the right resources. 
It is arguable that the institution of the global library, physical or virtual, is central to practically all metropolitan apparatuses of dissemination as a centrifuge for global dissemination, and closely allied to other alternative metropolitan agents of dissemination - publishers, prize awards institutions, the metropolitan academic curriculum, virtual and physical readers clubs, and importantly, the metropolitan bookseller in analogue or digital environments. These related 'holding' apparatuses function as what I will refer to as 'non-traditional' libraries in the sense that while they are non-permanent repositories they still do 'hold' books, and are conduits of dissemination, even if their depository functions are mediated by exchange value, symbolic and otherwise, rather than use value. Use value here refers to literacy or knowledge goals, that is, the need to expand knowledge economies, and cultural capital typical of traditional, subscription or research libraries within national or transnational school cultures and amongst different kinds of publics. These non-traditional libraries add to the aggregate 'currency' of a global library. Particular examples are Amazon, Barnes and Nobles and other online chains, or even readers' clubs, public-cum-private, like the Oprah reading club. African literature's insertion into these aggregate libraries is central to and a function of the global canon's canonical inclusion or exclusion. Those third generation works that are canonized at the centre are invariably listed or held by these non-traditional depositories as well as by the traditional library, their representation on such holdings being a marker of their global canonical stature.

The infrastructure of the traditional and non-traditional library is preponderant in the metropolis. So are the general social and material conditions, cultivated readership, literary market, and, importantly, buying power necessary for the survival of the book 
trade. This returns focus to the significance of place of publication in canon formation. Pascal Casanova emphasises the significance of place in her pregnant term 'literary capital.' His mapping of global literary space into geo-spatial hierarchies of literary capitals in figurative and literal terms within a "world republic of letters" is very lucid and logical.

The literary capitals of the world are London, New York, Paris, Belgium, and Toronto, Frankfurt - not necessarily Berlin - as so on. In an increasingly virtual world what has not been emphasised by Casanova is that the significance of place, 'literary space' or 'literary capital' vis-à-vis publication in his analyses should transcend mere physical location and incorporate the virtual - especially when thinking of "literary capital' in terms of ease of dissemination and consecration. This is because literary space or capital and its literal and symbolic permutations are repeated by virtual representation of such spaces or capitals as they congeal into virtual book-paths - data banks, book depositories, online bookstores, all imprinted in a centralized archive system called the Online Computer Library Centre (OCLC) initiated in 1967 as Ohio College Library Centre. Since its initial launch, OCLC is now made up of a network of other international and national libraries, all organised online as an archive referred to as 'world catalogue.' Other non-traditional online libraries - or depositories since these are sales outlets mentioned before, like Amazon and Barnes and Noble, feed that catalogue.

The importance and impact of the aggregate global library, virtual and physical, to dissemination is easily verifiable through the virtual data bank OCLC as a simple empiric experiment can establish by entering a search for sample third generation works published anywhere in the world into the online catalogue. The statistics reflected will 
corroborate my arguments about the significance of the global library to dissemination, canonicity and global canonical exclusion. In early 2012 when I first measured velocity of dissemination, 671 physical libraries worldwide held New-York-based and migrant Teju Cole's novel, Open City, published by Random House in New York only as recently as February 2011. In contrast Akin Adesokan's Roots in the Sky (2004) shows 21 worldwide library holdings despite its being published more than half a decade earlier. In February 2013 when I returned to the OCLC, Cole's work is held by 1101 libraries while global holding for Adesokan's work was at 20 , having reduced by 1 . One can safely assume that that disparity will keep widening at an arithmetic progression in the favour Cole's work.

The spatial distance - in terms of mileage travelled - between both works underscores the importance of the 'literary capital' in that poignant and double denotative and connotative sense in which Casanova deploys it. Cole is published in the literary capital of New York by a publisher who is globally visible, imbued with prestige and has a vast apparatus of dissemination. His work therefore has 'literary capital.' Adesokan is published by Festac Books, an unknown in international terms, whose mode of dissemination is relatively not as organised or targeted as that of the transnational corporation, Random House. The former publisher's circulation reach can be said to be dependent on accident, or 'good fortune' rather than conscious design. Adesokan's book therefore does not enjoy the 'literary capital' of an Open City - in terms, at least, of global visibility. Roots in the Sky is a hidden text, due to its being buried in the invisible context of the local retrieval canon in Lagos, although it also has literary merit. 
Nevertheless its fate represents that of a simple case of a potential classic being hidden to readership, to the curriculum and to scholarly critique due to literary 'ill fortune.'

The factors responsible for the disabling environment of the retrieval canon as discussed so far should not be understood as exhaustive but represent the most obvious; sometimes they overlap and reinforce each other and in combination aid in rendering a text 'invisible' or 'hidden.' I refer to the complex of those various factors and their interrelationship as 'total production'. The effect of a negative total production, which is engendered in the first place by an initial overarching retrieval canon, is that it is also the condition for an overarching enabling environment toward disabling and invisible contexts of literary production in the vernacular mode, resulting in hidden texts. This means that the operation of global canonical exclusion is enlarged by the disabling and invisible contexts of the local retrieval canon. The phenomenon of the hidden text is, of course, local as well as global due to the fluid and porous boundaries between writers and their location, between local literary production and global publishing and between local literary fashions, habits, traits, conditions and their transparent metropolitan re-inscription through a global school culture and its critical literary praxis.

The 'retrieval canon' has infiltrated the criticism of contemporary third generation writing to such an extent that those novels, which are at the intersections of the popular romance tradition of Onitsha market literature, Ibadan's Pacesetter Series, or the flashy and popular soft-sell Lagos magazines such as Hints, Classic or Prime People magazines of the late 1980 s and 1990 s, are read by aforementioned foundational critics like Bernth Lindfors, Charles Larson, or Wendy Griswold as part of the canon of new writing. The same can be said of third generation poetry, which urgent dystopic tones reduce them to 
the level of strident and flowery declamations. They are reminiscent of the staid political pamphleteering of early twentieth century Nigerian nationalists like Nnamdi Azikiwe or Denis Osadebey, which Obi Nwakanma retrieves as belonging to the first generation of serious modern Nigerian poetry ahead of Wole Soyinka, Christopher Okigbo or John Pepper Clark ("Narratives of the Nation" 2008). In noting the propagandist writing misrecognised as poetry by Nwakanma, I have referred elsewhere to those nationalists and politicians as "the Bandung poets"" (Ede, "The Bandung Poets" Sentinel \# 55, July 2007).

Some of the third generation novels and collections of stories - mere Unterhaltungsliteratur - belonging to a retrieval canon based either on their language, subject matter, plot, structure and a tendency for the sensational or on a combination of these include Toni Kan's Night of the Creaking Bed (2008) Unoma Azuah's Whistles in the Wind (2001), Kaine Agari's aforementioned Yellow Yellow (2006), Eghosa Imasuen's To Saint Patrick with Love (2008) and Abimbola Adunni Adelakun's Under the Brown Rusted Roofs (2008). That list is, of course, tentative and not exhaustive but simply highlights the most remarkable of the new writing in the retrieval mode.

Common to these works is the fact they are produced by the new generation of vanity presses that came into existence in the 1980 s and whose editorial review processes and technical quality are most of the time sub-standard. The novels or story collections are usually poorly produced popular fiction presented as 'literary works.' Their language is most of the time plain as exemplified previously with Yellow Yellow, their subject matter is pedestrian, the plot is contrived to make for a quick thrill, in other words, some of these works tend towards the popular thriller. This is signalled sometimes by a

\footnotetext{
${ }^{96}<$ See http://www.sentinelpoetry.org.uk/0707/editorial.htm>. Accessed February 7, 2013.
} 
narrative structure built on a 'cliff hanger' prologue as in Under the Brown Rusted Roofs. Again, as with Yellow Yellow, it is easy to exemplify the demerits of most of the works on the level of language, which is immediately striking in all of them.

After its prologue Adelakun's novel begins thus: "Afusa felt the first pangs of pain in her abdomen and she sat up from the clothes she was washing. She held her belly as she winced but the pain was only too brief. She resumed her work, throwing out the dirty water she had used in the direction of two blue dyed hens that quickly scampered away" (10). This is plain prose or everyday verbal usage and adequate in conveying what it seeks to. Beyond that there is nothing exceptionally 'literary' about that language or about the relationship of the parts of the sentences to each other. And Imasuen proceeds: "Chei, I hate rain, thought Superintendent of Police Ayo Nwanze of the Homicide Department, Benin Provincial Command, South-south Regional Police, as he got out of his unmarked Wazobia 306 saloon" (13). This is, again, simple straightforward telling.

Although the inadequate publishing infrastructure in the postcolony since the 1980s and the need to maintain reasonable costs might be an excusable rationale, the fact still remains that the works in question are unprofessionally printed. They are bound together by unusually thick paperbacks restraining mostly poor quality paper glued together roughly. Some of the publications have prelims containing unusually verbose acknowledgements - in Kan and Adelakun's case about a full page each of greetings. The commonplace and, often, sensational stories can be exemplified by Kan's work. The sexual innuendo of his title is already symptomatic of the sensational narration in that collection of stories. 
While Kan's plots and stories might have an appeal for certain audiences, their popular thrill is obvious on the level of language. Night of the Creaking Bed reveals a consistent stylistic preoccupation with suspense and the sensational, which is signified in a near-pornographic title embossed over an equally risqué cover image of a almost totally nude supine body of indistinct gender. The novel's modes of narration and dissemination - via the lurid paperback - is typical of the thriller stories and sexually suggestive graphics of Hints Magazine, where he happens to have started a scribal career. It is remarkable that Helon Habila, who like Kan, had his formative years at Hints magazine ${ }^{97}$ has transcended the limitations of such a shaky early formation to produce some of the most important works of the third generation like the recent Waiting for an Angel (2002) or Measuring Time (2007).

In the genre of poetry the retrieval canon is too numerous to count. Its incidence can be traced back to the urgent, existentially charged poetry of the 1980s. The following are some of their contemporary examples. I am memory (Verisimo 2008), Gentle Giants (Azubike 2008), $U$ are a Poet (Ayeni-Tsvende's 2007), Fossils (Maiwada 2008), Intercepted and Poems on the Run (Bassey, 1998, 1995). Before going back into the 1980s for foundational examples, I will like to review some contemporary incidence of the retrieval mode in third generation poetry.

The same careless writing observed in his fiction is evident in Kan's verse. A tendency for the pedestrian is emphasised in his poetry with its prosaic language and tired metaphors. Here is an example from "We sit in the Kitchen and Eat Chicken" in Songs of Absence and Despair (2009):

\footnotetext{
${ }^{97}$ See biographical notes on Helon Habila's online author website at $<$ http://www.helonhabila.com/About.html >. Assessed 8 February 2013.
} 
We sit in the kitchen and eat chicken

My mother smiles with sadness

Her smile is bright but her eyes are sad

The edges are coloured black with pain

And the remembrance of things past (10)

The highly charged and defamiliarised language of poetry is missing in the above, while the last two stanzas repeat the same prosaic diction. The echoing of a Marcel Proust (1913) allusion to Shakespeare in the line 'the remembrance of things past' fails to give the attempted poetic weight to the previous lines and merely emphasise the overall cumulative weakness of that first stanza.

It might be useful to focus on a poet who still personifies the stylistics of the inadequate variation of Nigerian Poetry of the 1980s, the better to show the linkage to the past and the continuation of poetry as message and angst due to the deteriorating existential conditions of the postcolony. Nimmo Bassey's Poems on the Run and Intercepted, both published in the 1990s, derive from the poet's ordeal at the hands of the Sani Abacha dictatorship. They are collections whose significance inheres in their urgent existential messages. "Gunrules" begins by directly addressing the former dictator, Sani Abacha, who is known to wear dark glasses at all times:

We saw you the other day

You stole, you looted, you didn't pay

Your teeth once gold, now gone purple

You hid your face behind dark goggles

When you 're gone we'll sure miss

What you'll agree is your death-kiss

We peeped behind your eyes

To break the ice 
You think you are cool

But your are just a fool (46)

This straightforward versified prose is sustained in most of the poems in that collection and continued in the other one. The one-stanza-poem, "Cops" in Intercepted is the same existentially urgent address:

When I behold a cop

I see a gun, a baton, a dark shirt

When I behold the teeth of a cop

I see no smile, no friendship no kinship

When the cop is your friend

I circle your shadow like

A shark embraces a loaded boat

When a pat lands on my back from the palm of a cop

I rush out bowls to collect my blood

When a cop traces a path

I pray may ours ne'er meet $(60)$

The rhetorical device of repetition in the above poem does not achieve its usual purposes of imbuing gravity upon lines. It becomes mere tautology. This sustenance of a retrieval canon in poetry that began when third generation poets came on the scene can be exemplified in the signal publication, Voices From the Fringe and in some simultaneous poetry collections announcing the birth of the new crop of writers.

In Raji's historiography of the 1980s literary renaissance in Nigeria, "From the Poetry Club to the premier Circle" (English in Africa 2005: 21-35) some of the poems proffered as examples of the Ibadan Poetry Club's chapbook production are better described as juvenilia. The critic does not make this qualification and gives us such examples as the one by Godwin Erapi:

Our leaders came,

To see us die, Then they left, To continue their merriment, And their globetrotting, 
Even the Chief Security Officer,

Went to see the leader off.

We in the blazing inferno

Gave your indulgence

With our last breath

Please this message take to all Nigerians

"We who are about to die,

Salute you all." (Poetry Club 1983, 6 quoted in English in Africa, 2005: 24)

Apart from the punctuational rashes of the above lines, which does not further meaning or poetic effect, their prosaicness is exposed and emphasised by the forced, selfconscious inversion, 'please this message take to all Nigerians' - as if the writer realises the flatness of his lines at last and tries to inject 'poetry' into that versified prose. There are other examples of this sort proffered by Raji.

The retrieval approach to new writing is evident in Harry Garuba's discussion of third generation poetry in the same journal, where he exemplifies the 1980s efflorescence of new Nigerian poetry with examples from the poetry of the period. An example from Emman Usman Shehu's "Folkland" in his first collection, Questions for Big Brother, will suffice:

please tell mister don lee

I wont change my name

NO

I wont change my name

I remain the same

CONTRADICTION

I am what I am (quoted in English in Africa, 2005: 62)

Again the lines are prosaic, weak and forced. The false energy in "Folkland" is announced in the capitalised, and bold, 'NO', which seeks to assert the writer's defiance, but in so unnatural a manner that it requires the help of capitalisation and a bold point size. The second capitalization in the same stanza, 'CONTRADICTION', confirms that 
weakness, even as the poem seeks to assert the poet persona's defiance to some imaginary authority figure, "mister don lee." The overall effect of this work is that of being contrived. Another poem from the same collection, as quoted by Garuba (ibid. 63), will confirm this:

Peter pan peter pan

Catch me if you can

I don't want to know

How to be a Nigerian

The nursery rhyme appeal of that first quatrain above robs the eventual entire poem of the heightened speech of poetry. Poetry of course can be simple but it should be in such a manner that its simplicity of diction and phrasing is only an artifice to emphasise the strength of the whole utterance. There is a good example in the first generation poet, John Pepper Clark's, "Stream Side Exchange" between a bird and a child:

Child:

River bird, river bird,

Sitting all day long

On hook over grass,

River bird, river bird,

Sing to me a song

Of all that pass

And say,

Will mother come back today?

Bird:

You cannot know

And should not bother;

Tide and market come and go

And so shall your mother 
In the above poem, the sing-song nursery-rhyme-like exchange is nevertheless a powerful invocation of the anxieties of human beings over the future through the evocative imagery, the punctuational restraint suggesting the child's anxieties, and the finality of the last two lines, "tide and market come and go/ And so shall your mother", which echo the child's concerns over the future, the cumulative power of the poem and emphasises the theme of the inevitability of change.

The reality of the critical tendency to merely record what is produced or is being produced by Nigeria's third generation as elaborated above does not preclude the fact that these critics also acknowledge the truly inspiring. Critics of the third generation's oeuvre, some of whom are creative writers themselves, are cognisant of which works make the bulk of a truly literary canon. Perhaps the sense of a renaissance in the third generation relative to the previous two, predispose them to ignoring the shortcomings of some of the new writing.

While the above-named critics could be described as generous in their validation of a retrieval canon, the aforementioned Obi Nwakanma is a scholar whose version of the retrieval canon appears to be shaped by ethnic filiations if we consider his partisan critical submissions for revising the Nigerian canon. That ethnic criticism is implicit when he, being Igbo, avers that Nigerian writers "of 'Igbo extraction' are significantly more present in the emerging picture of the Nigerian canon" ("Narrative of the Nation" 4). He then recalibrates the generally agreed generational divide in Nigerian literature to extend further back and incorporate those nationalist politicians discussed earlier. His partisan calculation swells the ranks of writers of 'Igbo extraction' in order to legitimize his probing of a (vexed) Igbo nationalism in Nigerian literature. He configures a "third 
and fourth generation" (4), the better to retrieve Dennis Osadebey and Nnamdi Azikiwe, who are Igbo, as part of the first generation of Nigerian writers. This then seems to rationalise his re-conceptualisation of Nigerian literary generations. "Modern Nigerian literature can now be categorized in three to four movements, or generations, starting with the Azikiwe/Osadebe generation of nationalist poets [...]" (1). In this programmatically ethnic view of a Nigerian canon he does not give the rationale for displacing the already critically accepted generational markers, with colonialism as a dividing line, between the first two generations and a third and contemporary one in a special issue of the journal, English in Africa (2005).

It appears that one of Nnwakanma's goals is to clear the ground for ethnic criticism and retrieve pre-independence political pamphleteering as examples of first generation Nigerian poetry. While those anti-colonial politicians of the pre-independence era may be referred to as pioneers in the sense that they set down their political thoughts in ink through the medium of a new technology of writing (Ong "Orality and literacy" in Book History Reader Finkelstein and McCleery. 2002: 105-117), they certainly cannot be referred to as novelists or poets but as 'writers' or authors in a generic sense. Nwakanma conscripts and seriously considers for canonisation nationalist politicians like Dennis Osadebay and Nnamdi Azikiwe ahead of Chinua Achebe, Wole Soyinka, John Bekederemo Clark or Christopher Okigbo, Amos Tutuola et al as belonging to the first generation of modern Nigerian letters. This, yet again, probes the relationship between the idea of nation and identity within the Nigerian canon. These questions are complicated into urgent psychic displacements of subjects, nation, narration and, 
belonging when couched in terms of a literary Diaspora as distinct from the exilic and the hitherto NLNG-de-nationalised-migrant Nigerian writer.

Matters of Diaspora, identity and the Nigerian canon are enlarged when they relate to writers of the Black Atlantic like Oluadah Equiano, who is usually 'retrieved' not necessarily in a derogatory canonical sense - without much qualification as Nigerian, and in extreme and ethnic cases, as an Igbo writer (Acholonu The Igbo Roots of Oluadah Equiano c.1989; Egude No Roots Here 1989). His metropolitan transformation as Gustavus Vassa, is occluded in such retrieval canons. There is a sense in which a temporally distant Equiano could easily be argued to be as much a Black British writer as are members of a more recent Diaspora like Helen Oyeyemi, Diran Adebayo, Jackie Kay, Sade Adeniran, Segun Afolabi, Carole Enahoro or Diana Evans.

The above diasporic rather than migrant, exiled, or local Nigerian writers function at the intersections of globalisation and nationality. As such the aesthetic, thematic and value categories inherent in the idea of nation as a literary geo-political space, and its physical boundedness - enlarged in the suffocating pseudo-nativism of a Chinweizu et al (Towards the Decolonization of African Literature 1983) - needs to be more open ended and embrace disaporic cleavages. It is towards such a purpose that Irele's (2001) idea of an 'African imagination' incorporates the unpredictability and instabilities of the travelling, travelled, migrant, exiled, and especially diasporic text in a larger black world.

The sociological approach to the idea of a Nigerian retrieval canon - especially in its negative aesthetic appearance - might be tenable within the logic of a literature that is recent and relatively new, still extending its parameters and which needs to be 'retrieved' in all its variables. Nevertheless my understanding of a Nigerian canon - especially as 
juxtaposed with an exclusive global canon - is represented by that corpus of works in English which have symbolic capital as recognized by local or global literary validation. Indigenous language literatures are hardly ever going to be in consideration for global canonisation in the foreseeable future. They are peripheral, in more sense than one, to the business of modern global culture.

Even if the prevalent diachronic, socio-chronological approach to Nigerian literary canons particularly and the African generally, is tenable as a form of retrieval, there is a need to synchronically discriminate between the popular, trivia or the purely literary, especially in relation to the aesthetic requirements of world literature and a exclusive global canon. Nevertheless, the question of what is literary, as implicated in judgements about value, is shown by critics from different discursive approaches as not being completely disinterested; nor is value itself totally value-free (Sartre What is Literature 1965: 113-116). Besides tastes and value do change with time as elaborated in Eagleton's Marxist conclusions about the changes in literary fashion from preference for writings in Latin to those in 'vernacular' English or French in accordance with fluctuating class formations in eighteenth-century England (Literary Theory 16ff, Eagleton The Event of Literature 2012:19ff; 59ff). However it is still possible for the honest lay reader to immediately recognise it when they are in the presence of the literary; this is even more so for the trained literary critic. Although, as suggested above, class and ethnic nationalism do sometimes intervene in contemporary formulations about the Nigerian canon considering that the very act of criticism itself is "not an innocent discipline and never has been" (Eagleton, Criticism and Ideology 1976: 17) there still ought to be a clearly demarcated measure of standard in contemporary Nigerian writing 
consonant with prevalent and common sense notions of what constitutes the literary. This is possible if criticism as a discipline becomes self-reflexive (Ibid.17). Irrespective of its politics and problematic, and sometimes lack of disinterestedness, the literary prize, local or global, as a fact in itself, is one of the markers of that standard.

\section{Local Literary Promotion and Global Canonical Exclusion}

The retrieval canon has important ramifications for global canonical exclusion in the sense that it restricts an already marginalised body of literature due to its refusal to critically midwife works of clear literary worth and separate these from the popular, the trite and mediocre and from Unterhaltungsliteratur. The moral of the dilution possible due to a lowering of standards is reflected in Bernth Lindfors' (Early Nigerian Literature 1982) discussion of late 1950s local Nigerian critics' dissatisfaction with an expanding British publishing industry's indiscriminate sourcing of manuscripts of dubious literary quality. Lindfors reports an irate critic as having exclaimed that: "[t]hird and fourth rate writers in the country of the blind then acquire the fame and standing of first rate writers in more enlightened countries" (7).

That complaint by an unnamed critic will readily apply to the local situation in contemporary Nigerian literary circles. In this case it is local small presses, trade publishers, literary clubs, writers' bodies, and the over-generous critic who celebrate substandard writing in a bid to promote literature. While these efforts help to nurture good writing at some level they also devolve into the production of an unwitting local retrieval canon. One notable example of these promotional efforts is the 9 Writers; 4 Cities: The Book Tour in $2009^{98}$. It included local writers Igoni Barret (the organiser)

\footnotetext{
${ }^{98}$ See Sumaila Isa Umaisha's blog on the subject at $<$ http://everythinliterature.blogspot.ca/2009/04/9writers-4-cities-book-tour.html>. Assessed 11 February 2013.
} 
Toni Kan Onwordi, Jumoke Verissimo, Odia Ofeimun, Abimbola Adelakun, Eghosa Imasuen and others. Certainly it is a mixed crowd of the best of writers and some cultural producers of Unterhaltungsliteratur. Odia Ofeimun is a second generation writer of acclaim, who won the Fonlon-Nicols Award of the African Literature Association based in the USA in 2010 for his immense contribution to African literature as a seasoned poet.

Another of such promotional efforts is the monthly BookJam reading series ${ }^{99}$ begun in Lagos in 2010 and organised, again, by Igoni Barret in collaboration with, and sponsorsed by the corporate body, Silverbirds Lifestyle Media (Jani "Latest Book Jam" Books Live blog 07 May, 2010) ${ }^{100}$. While it took off with the highest of literary developmental goals and a roster of seasoned local writers, the series has been taken over by the sponsoring corporate body, Silverbird. It is arguable that this transfer has not been good for the series, whose quality has become suspect due to its being expanded to incorporate those writers who should still be honing their craft, some of whom also participated in the 9 writers; 4 cities book tour.

The argument is not that such public readings are not important for the development of Nigerian literature - especially writing by local talents, but rather that such talents should first complete periods of apprenticeship, formal and informal - such as provided by the creative writing workshops organised by Chimanda Ngozi Adichie in collaboration with Fidelity Bank PLC, who sponsors it, and which began in $2007^{101}$

\footnotetext{
${ }^{99}$ See Molara Wood's blog at < http://wordsbody.blogspot.ca/2010/05/bookjam-4.html>. Assessed 11 February, 2013.

${ }^{100}$ See < http://bookslive.co.za/blog/2010/05/07/notes-from-the-latest-bookjam-silverbird-in-lagos/>. Assessed 11 February, 2013

${ }^{101}$ see "Watershed in Community Relations" at

$<$ http://www.fidelitybankplc.com/newsdetail.asp?newsid=30>. Assessed 11 February 2013. See also
} 
(Kanu "Interview with Chimamanda Adichie" Nigerian Village Square 08 August $2007)^{102}$ It set high literary goals and has featured acclaimed third generation writers like Helon Habila, Chimamanda Ngozi Adichie, and other equally inspiring international cultural producers like the Kenyan, British, Zimbawean and Canadian writers Binyavanga Wainaina, Michela Wong, Tsitsi Dangaremgba and Madeleine Thien respectively.

Despite the kind of efforts detailed above and even when local writers are willing to apply themselves to learning the craft, corporate literary promotion becomes problematic due to the sponsors' interference and overzealousness. All too often Nigerian corporations invest in literary promotion for public relations or other business benefits as with every other business concern globally. The difference between international sponsors and Nigerian corporate bodies is that the latter, laudable as their efforts are, are either not satisfied with mere sponsorship and insist on sitting on boards and administering or want to have complete control and overall stewardship. This has been the case with the BookJam reading series ${ }^{103}$ as well as the Fidelity Bank creative writing workshop, whose original respective inspiration, Igoni Barret and Chimamanda Ngozi Adichie, have departed. The result of such mis-collaborations is a lack of continuity, a lowering of standards and the proliferation of a retrieval canon.

When discordant literary promotion combines with self- or vanity publishing, unprofessional literary production - in the form of non-existent or careless peer review

\footnotetext{
${ }^{102}<$ http://nigeriavillagesquare.com/articles/ahaoma-kanu/interview-this-is-not-just-my-prize-but-our-prizechimamanda-adichie.html >. Assessed on 11 February, 2013

103 see Olushola Ojikutu's "BookJam Changes Hands" at http://234next.com/csp/cms/sites/Next/ArtsandCulture/Books/5600240-147/story.csp >. Assessed February $18,2011$.
} 
processes, poor editing, poor pre-press and press work (wrong typeface, careless typography, and bad choice of paper and ink etc) and poor finishing - the result is an explosion of a retrieval canon that now proliferates. While, in rare instances, vanity publishing could result in a work of literary merit, clear aesthetic value and competent production, the usual case is that the activities of the small press result in the opposite.

While the increased involvement of Nigerian businesses in literary patronage over-emphasise corporate self-promotion and literary activity as entertainment to the detriment of literature as serious vocational engagement, the proliferation of the small or vanity press, with mostly shoddy editorial and production quality, exacerbates a local retrieval canon. The combined impact of self-serving literary promotion, unprofessional small presses, and the retrieval canon of writing they produce resulted in such distaste in the literary community that the judges of the 2009 NLNG prize for literature refused to award its poetry prize, citing poor literary and publishing quality as justification (Sule "After the Storm" African Writer 2 December, 2009) ${ }^{104}$. While there are informal discussion about the poor state of literature and publishing in Nigeria, the arrowhead of a formal critique has been, notably, Charles Nnolim in "Contemplating Contemporary Nigerian Fiction" (Nigerian Guardian, 5 August 2005). Despite a prescriptive, moralising tone, the central argument of his critique, namely that the local literary production of the third generation writer is substandard, is still valid in degrees. It is such a situation that the local Nigerian literary prize is supposed to curtail. In how far has the promise of local consecration raised literary quality?

\footnotetext{
${ }^{104} \mathrm{See}$ article at $<\mathrm{http}: / / \mathrm{www}$.africanwriter.com/after-the-storm-nlng-poetry-prizes-report-and-mattersarising/>. Assessed 11 February 2013.
} 
The literary prize, whatever its inconsistencies, is one certain avenue for the consecration of authors and the formation of canons ${ }^{105}$ in any literary space (Economy of Prestige 2005). Beyond the school and university curriculum as a quasi-official local canon-forming instrument ${ }^{106}$, contemporary Nigerian writing has included the literary prize as an alternative and more visible canon forming mechanism since the $1980 \mathrm{~s}$. In the prevailing economic collapse of that period and its devastating effect on an already struggling publishing industry (Bearing Witness 69; Osha "Writing in a Continent Under Siege" 1998:776), Chinua Achebe founded the Association of Nigerian Authors (ANA) in 1981, with the stated goals of giving Nigerian writing a much needed fillip. Its objectives were "the promotion of Nigerian literature, written and oral; the enhancement of the well-being of Nigerian writers and protection of their rights; the stimulation and development of indigenous talents, skill and intellectual powers; and the promotion and development of the book culture" ("Writers' Burden" 137). It is significant that the beginning of the Association coincided with the emergence of new writers within the Nigerian literary field. On the one hand, it was a response to the restless energy and creative ferment of these new writers, and on the other, an institutional support for harvesting the nascent literary renaissance, which was in full flower by the mid-1980s.

\footnotetext{
${ }^{105}$ Perhaps Odozor does not give attention to literary prizes or any other canon forming process like the school curriculum because for a young literature, literary prizes are equally a new phenomenon. Perhaps the newness is precisely what warrants a discussion of prizes in a scholarly work focussing on canon, whether as merely a list of books or not. Besides he does not mention any of the newer writers, even though his work is described with the word, 'contemporary Nigerian Writing.' Most of his primary literature is made up of work written by the first and second generation of Nigerian writers. As far as prizes go there has always been some canon forming instruments such as informal 'prizes' as a form of communal consecration or acceptance or rejection, even for indigenous oral literature.

${ }^{106}$ In Long Drums and Canons Bernth Lindfors bases his yardstick for deciding what work of African literature is deemed canonical on the empiric frequency of their appearance on school or university reading lists.
} 
The establishment of ANA meant that writers' clubs and literary coteries around the country sprinkled mostly about the South and East of the country in a literary geospatial configuration now referred to as the Lagos-Ibadan and Nsukka axes respectively ("Children of the Anthill" 37) came together under a single umbrella body. It resulted in increased literary production and lack of publishing outlets for the restless young writers (Voices from the Fringe xv).

The result of the restiveness of the third generation writer was ANA's sponsoring of the publication of six individual debut poetry collections from third generation writers' manuscripts, which had won the body's poetry prizes at different times. At the same time the generation-defining poetry anthology, Voices from the Fringe in 1988 ("Children of the Anthill" 37; "Third Generation" 9; "Ibadan and Memory" 21) was also published ${ }^{107}$. This publishing effort was an initiative by ANA in cooperation with corporate sponsorship. Although the association established prizes in all the major genres as mentioned earlier, the prospects of consecration, rather than result in careful production by the new writers, nevertheless had the strange effect of driving them into careless writing - one reason being that, as discussed earlier, ANA initially accepted the entry of unpublished manuscripts for its prizes due to scarce publishing infrastructure. The new writers then rushed out manuscripts.

The growth of a retrieval canon in contemporary writing can then be said to have emerged concurrently with the third generation in the 1980s. Voices from the Fringe began this tradition in its effort to assuage very limited publication outlets, and retrieve material that had no other possibility of dissemination. A cursory reading of the poems

\footnotetext{
${ }^{107}$ See Harry Garuba's introduction to his edited Voice from the Fringe for a full account of the conditions surrounding the publication of this seminal poetry anthology of the third generation.
} 
collected in the volume will show that poets who still had to go through proper apprenticeship were published along with those who had promise far ahead of their peers. This compromise probably was in the hope that an appearance in a book form would encourage self-application in those budding poets. Indications of a burgeoning retrieval canon were announced by the gradual politicisation of ANA - as with most human endeavours - by controversies over the quality of winning entries and by the new crop of writers' loud protestations whenever older writers won prizes in a row, suggesting the veterans' dominance might be a result of inbreeding.

I have dwelt a while on poetry because this was the dominant genre of the third generation ("Third Generation" 8-9), over and above the novel or drama, when it came into prominence. A couple of socio-economic and institutional factors were responsible for this. One of them was economic, as I have been arguing. It can be said that in the prevailing economic depression following president Ibrahim Babangida's IMF-induced Structural Adjustment Program, it was economically viable to write poetry, where conditions did not allow for the luxury of works which required long periods of planning, conceptualisation and preparation.

The dominant themes of the period were quite expectedly ones of dystopia as elaborated upon in chapter two above. The young poet did not have the emotional quietude, the financial means, or the publishing outlet to concentrate on long sustained works like the novel as suggested. In the introduction to this dissertation I remarked that the only serious novel published from the mid-1980s to early 1990 s was Omowunmi Segun's The Third Dimple (1992). Other prose works were Karen King Aribisala' Our Wife and Other Stories (1990) and Sola Osofisan's short story collection, The Living and 
the Dead (1991). The urgent economic, political, existential and psychic distractions of the postcolony, attracted the urgency of poetry as with most urgent literary periods - for example this was the case in post-war Europe, during African decolonisation and in apartheid-era South Africa.

In the midst of economic uncertainties, a lack of adequate publishing infrastructure and a proliferation of hurriedly prepared and shoddy manuscripts, substandard material was allowed to compete for and did win the ANA literary prizes. This was mainly due to satisfy a hankering by new writers for literary visibility and possibly more publishing outlets. This lowering of standards brought the laudable intention of consecration into the retrieval mode of canon formation. Apart from other metropolitan factors, the consequences of a politicisation of the literary field and a foundational critical generosity by the local Nigerian academy and literary establishment, has proven to be that the potential flow of third generation Nigerian writing into an already restrictive global canonical has become a trickle.

It is nevertheless legitimate to claim that there is literature of comparable metropolitan standard being produced in the country if we consider Helon Habila's Prison Notes, self-published in Nigeria ironically, and which went on to win the British Caine prize for African writing. That launched his literary career globally. Nevertheless the canonical inclusion of Habila, necessarily suggests the exclusion of other equally world-class literary production (such as Maik Nwosu's Invisible Chapters), which have been swamped and are lost within a local retrieval canon. Even where a local work of global literary standard wins a Nigerian literary prize, the lack of proper dissemination of such prize-winning publication, confines it to the borders of the country. It is pertinent at 
this point to take a closer look at the dynamic between the transnational retrieval canon and global canon formation. 


\section{Chapter Five}

\section{Navigating the Retrieval Canon}

The central argument in the preceding sections of this dissertation is that an ideological inequality and a critical bias circumscribe the metropolitan institutional valuation of African literature resulting, by and large, in its marginalisation. The present chapter posits that critical predisposition as having become normalised - not only due to the resilience of global canonical exclusion but also because of the centre's control and overwhelming of the symbolic economy of the periphery to such an extent that local imagination unconsciously over-valorises consecration from that centre, upon which it sometimes relies too heavily for self-validation.

So far the arguments in this dissertation have been couched largely in terms of a delineation of a metropolitan management of the margins. This approach has been necessary due to the historical overwhelming globalising force of an ideological and a value-forming core as such. Loreta Stec underscores the near fixity of that core despite twentieth century's relative rise of the postcolonial novel. In spite of serious political challenges to the British canon, old hierarchies are maintained due to "centripetal forces [economic and otherwise] that push book lists of publishers toward a center" $(1997: 141)$ where some grounds may be yielded but in which old orders are eventually reestablished. Stec buttresses her assertion about the centrifugal tendencies of the global canon by referencing Gayatri Spivak's convictions in "Scattered Speculation on the Question of Value" that:

the deconstructive impulse attempts to decenter the desire for the canon $[\ldots]$ Yet $[\ldots]$ it is a truism that a full undoing of the canon-apocrypha 
opposition, like the undoing of any opposition, is impossible [...]When we [are] moved by a desire for alternative canon-formations, we work with varieties of and variations upon the old standards. (1988: 154 qtd in Stec 141)

While Spivak's observation above as quoted by Stec might be qualified by saying that decentring the centre is impossible precisely because of the historically-constructed geopolitical power configurations in the world, it is still an incontrovertible validation of the overwhelming of the margins by the centre in cultural matters. Culture is so intertwined with the political that a change in canonical hierarchies would require a change in the geo-political dynamic of power.

Of immediate significance here is that the spectre of impossibility in Spivak's commentary above arises precisely because the global canon's ideological and aesthetic inequalities are paradoxically sustained in the periphery through that literary space's historical cultural subordination to the centre in the first instance. That cultural dependency is enlarged by local economic, aesthetic and critical constraints on literary production resulting in the burgeoning of a retrieval canon, which further complicates the restrictive effect of global canonical exclusion.

It is therefore pertinent to ask: how do third generation Nigerian writers navigate, in practical terms, the disabling invisible context of local retrieval in preparation for their self-positioning within a larger metropolitan field of cultural production and its canonforming apparatus? Particular examples will prove that, through authorial design rather than by accident, some valued writing by local Nigerian writers does escape the contamination of a local retrieval canon and arrive within metropolitan canon formation 
as consecrated texts enjoying wide dissemination, and sometimes inclusion in the canon of world literature, even if in token canonical terms as I have argued consistently.

\section{Escaping Local Retrieval}

The centrifugal repelling force of global canonical exclusion is so overwhelming that third generation writers of fiction try to circumvent the prospect of their work's disappearance within Nigeria's local retrieval canon as hidden texts by courting international agents, or publishers of print material and online journals to get closer to the canon forming process of the centre. Those who, by inclination and temperament are poets, experiment with fiction - as is the case with Lola Shoneyin and Toyin AdewaleGabriel - since fiction, rather then poetry or drama, is the preferred genre for global canonical considerations, and the one most likely to bring international recognition. Some third generation fiction writers try to influence the incorporation of their work into school cultures, national and international, through contacts in the academic field, and by personally seeing to it that representative agents and publishers enter their work ${ }^{108}$ for international literary prizes. This is especially because local prizes preclude the extensive reach of metropolitan dissemination, which can propel a text beyond the borders of the country. An example is Adaobi Tricia Nwuabani's I Do Not Come to You. She wrote the manuscript in Nigeria, deliberately ${ }^{109}$ sourced it out through a foreign agent to a

\footnotetext{
${ }^{108}$ It is normal that some of these writers, as is their right, do solicit the publisher to enter their work for international prizes from my personal experience as editor of the Maple Tree literary supplement.

${ }^{109}$ In an interview I conducted with the author, she says: "My book, I Do Not Come to You by Chance, was first published in 2009. Prior to that, I hadn't left Nigeria-not even to Ghana-since 2005. It all started with my literary agent, Daniel Lazar. I found him online, after a Google search led me to a website called agentquery.com. Before signing with Mr. Lazar, I had sent my manuscript to dozens of agents in the UK. To get round the tortuous process of mailing thick envelopes with my query letter and first three chapters in them all the way from Nigeria to the UK (meanwhile, you and I know that the Nigerian Postal Service might very well have decided to let my parcels sit in their offices for decades), I asked various friends who lived in the UK for assistance. Each friend received my first three chapters and a query letter, and a different agent's address to mail their package to. Mr. Lazar was one of the very few agents I encountered
} 
metropolitan publisher. The manuscript was published in the literary capital of New York to metropolitan acclaim.

As discussed in chapter three, the subsequent canonisation of I Do Not Come to You as part of world literature cannot be dissociated from its self-anthropologising subject of Nigerian advance fee fraud - (in)famously named after the Nigerian Criminal Code, subsection 419 as ' 419 scam' - coupled with the manuscript's strategic placement with Hyperion, an imprint of Walt Disney. This is an international publishing conglomerate with an extensive media network for dissemination. The publisher apparently seized on the work's self-anthologising mode as a promotional strength. It is noteworthy that Hyperion is better known for general interest books and popular fiction, which better describes Nwaubani's work even if it ironically goes on to win an international prize. While it can be argued that literary tastes do change over time as Terry Eagleton argues eloquently in Literary Theory (1983), such changes are not yet so universal that I Do Not Come to You may be considered as mainly a 'literary' effort. Nevertheless the novel eventually won Britain's Africa region Commonwealth Writers Prize for Best First Book, completing its journey into the canon of world literature. So overpowering is the stereotypical image of Nigeria, and Africa, that it wittingly or unwittingly projects.

In extreme cases local writers assume the additional role of publisher and distributor in order to escape the strictures of the retrieval canon as empowered by the

online, who stated that they were happy to receive email queries. Most insisted on snail mail. And so it was that; even before the many agents my friends had sent out to had the time to receive, read and send rejections; Mr. Lazar had read my manuscript and offered me a contract. After about six weeks of back and forth editing, Mr. Lazar then went on to sell I Do Not Come to You by Chance to the US, later to the UK, France, Germany ... I've never met him. All our interaction, so far, has been virtual." See also her advise and commentary on publishing to young Nigerian writers in "You don't have to Swim Across the Atlantic" at <http://234next.com/csp/cms/sites/Next/ArtsandCulture/Books/5421062-147/story.csp>. Accessed 6 June 2010. 
vanity or small press. Although some quality fiction, poetry or drama might be issued by vanity presses or through self-publishing it is common that such efforts simply shortcircuit peer review and editorial processes and publish 'authorised' but substandard material. They are hardly ever successful in local literary terms or in global canonical effect. Nevertheless, it is ironic that in the rare case of the potential world class writer, who is self-critical and conscious of literary standards but trapped in the invisible working contexts of local retrieval, it is one of those conduits of retrieval - selfpublishing - which becomes the exit trajectory out of that suffocation. Such a scenario is one in which the excellent material that would otherwise end up as a hidden text gets salvaged from the invisible context of retrieval by direct authorial intervention.

Helon Habila's prompt salvage effort with regard to the manuscript of his work that later became the metropolitan award-winning Waiting for an Angel (WFA) (2002) is a very good instance. The publication history of that work is reflective of Pierre Bourdieu's dramatic cultural producer as an agent who strategically self-positions within the field of cultural production towards particular consecrating goals. According to Habila ${ }^{110}$ he simply registered a publishing company in Lagos, Epik Books, secured an ISBN and hired a local printer to carry out presswork. The bound book carried the original title, Prison Stories and was issued in 2001. He then wrote an introductory letter as publisher of his own work, entering one of the stories in the collection for the British Caine prize, which it happened to have duly won. Hamish Hamilton in London, who issued it as WFA, acquired Prison Stories in an extended form. The result went on to win the British Commonwealth Writers Prize in the Best First Book category for the Africa

\footnotetext{
${ }^{110}$ The writer, who happens to be a personal friend and fellow member of the third generation, confirmed this to me in a phone conversation.
} 
region. In this way Habila was ushered into the canon of World Literature and has sustained his initial success with Measuring Time (2007), and Oil on Water (2010), which was shortlisted for the Commonwealth fiction prize in 2011.

The significance of Habila's self-positioning with his work in relation to the field is that he exemplifies how the agent's disposition is often circumscribed by metanarratives of literary production which enhance his position, put him at a vantage point and at one remove from the goal of consecration and canonisation. While such metanarratives are paratextual social relations of production influencing actual technologies of production and dissemination to the advantage of the agent, they can also be ultra-textual in the sense of a physical self-awareness of the text itself - elegance of style, elevated diction, or the kind of textual self-parody displayed in Habila's WFA to such an extent that the physical act of writing itself becomes a commentary on writing as a liberating political tool, and a self-reflexive therapeutic act for the protagonist, Lomba, who in the story "Love Poems" at the beginning of the collection, deliberately sets out to write a diary as a kind of survival tactic.

While the interlinked collection of stories in WFA screams its overall ultratextuality by insistently directing the reader's imagination to general extra-textual narrative compliments in the physical world, this meta-narrative ambience is particularly emphasised by the comingling of real life members of the political opposition - Nigeria's literati - and fictional ones as characters in the story titled 'James' within the collection. Odia Ofeimun, Chiedu Ezeanah, Maik Nwosu, Nduka Otiono, Mike Jimoh, Obi Nwakanma, Akin Adesokan, Ogaga Ifowodo are not only flesh-and-blood actors in Nigeria's literary circle but also fictionalised characters in WFA alongside fictitious 
protagonist, Lomba and James, the former's boss and, newspaper editor. These two are easily archetypes for the many beleaguered editorial staff of real life publications such as Tell Magazine, Tempo and so on. Two notable examples are the Journalists, Kunle Ajibade (Jailed for Life 2003) and Chris N. Anyanwu (Days of Terror 2002). The fictional world created is one of writers and journalists working (together) in a country "under siege" (Osha 1998), and doubling as think-tank, as a moral force and as activists representing the national conscience. They meet to plan strategies, get drunk, flirt, read poems of defiance and solidarise as artists, citizens, and fighters for justice. The metanarrative brio reaches fever pitch as the author is fictionalised in his own story as himself, Helon Habila:

"Someone rushes out and leans over the rails and throws up.

"Hi, he says to Lomba, wiping his mouth with his hand, I am Helon

Habila." Another one follows almost immediately; he vomits and introduces himself, "Hi, I am Toni Kan."

They keep coming

"Hi, Chiedu,"

"Hi Otiono,"

"Hi Maik"

"Hi Nwakanma"

"Hi Mike Jimoh" (215-216).

All the above first names are of contemporary writers practising in Nigeria at the time the author was writing the novel. 
The meeting of journalists and writers - real and imagined - in James' home is the occasion for a solidarity reading for "two young poets who were arrested yesterday. Akin and Ogaga" (211). Both 'Akin' and 'Ogaga' are the author's contemporaries and friends, one a novelist, and journalist with "The News," the other a poet. They are traumatised in the real and fictional world of the work and are archetypes for Everyman jailed by General Sanni Abacha, whose uncanny barbarity is described by Wole Soyinka" as "stone age despotism" (see Adebanwi Trials and Triumphs 2008: 108).

In the opening story of WFA, "Love Poems," the protagonist, Lomba's incarceration and struggle for survival is simultaneous with the imagined prison travails of fictionalised but real-life figures like the aforementioned Akin Adesokan and Ogaga Ifowodo, and non-fictionalised but other equally jailed writers and journalists or activists like the Kunle Ajibade and Chris Anyanwu above, or Nimmo Bassey. Other factual political upheavals are represented either with a fictional slant or exactly as they happened to actors in the real world - like the political assassination of the journalist, Dele Giwa of Tell Magazine, by parcel bomb $(196-197,203)$, the 1995 judicial murder of Ken Saro-Wiwa (228), writer and environmental rights activist, by the Sanni Abacha regime; the "Abiola riots" in Lagos, where fictionalised southerner and Yoruba man "was burnt to death in his car [because the mob thought] he was a northerner" (145), emphasising the complication, group disaffections and antagonism even within a prevailing dystopia.

Habila's invocation of the name, 'Abiola,' recalls unanswered national political questions due to the incumbent president, Ibrahim Babangida's, annulment of a free and fair presidential election in Nigeria on June 12, 1993. The democratically elected winner,

${ }^{111}$ Soyinka caricatures Abacha as dictator protagonist of the play, King Baabu. 
Moshood Abiola, was barred from holding office. While faction as a literary technique is commonplace enough in itself, what is unique in WFA is the suspension of that temporal backward scanning typical in historical narration for an urgency in the time of narration. Here events in the fictional world are often simultaneous and continuous with those in the real. In other words Habila's subject - the brutality and precariousness of life under military dictatorship in Nigeria - is narrated as it happens and is framed in tandem with its unfolding. The factionalised events are contemporaneous with similar occurrences in the real such that the distinction between fiction and fact are blurred more than usual. This journalistic component of WFA - which nevertheless escapes mere journalese underscores the raw urgency of a state of political emergency in the country at the moment of writing.

In terms of global canonical exclusion what WFA's narrative technique does is to draw global critical attention to the work itself as a piece of realistic fiction steeped in the harsh realities of a repressive Nigeria against a global political zeitgeist of freedom and democratic governance, willy-nilly confirming the perennial stereotypes of Africa as a place of crisis and of ravages. As such the effect of self-anthropologising in WFA is pervasive, since the narrative directly mirrors the dystopic world unfolding immediately outside the text: extra-judicial murder, mass incarceration, repression and global political alienation.

That anthropological imperative is emphasised when James as mentor and editor persuades Lomba, his reporter and journalist, to cover a potentially dangerous prodemocracy demonstration and protest event. James' argument is that the atmosphere of un-freedom in the country nullifies the existence or relevance of Lomba, who is an 
aspiring novelist, if the latter cannot publish his prospective work locally due to the economic depressions attending misrule, or because of being barred from international publication or competitions as well due to the alienation of Nigeria from the global political community:

You won't find a publisher in this country because it'd be economically unwise for any publisher to waste his scarce paper to publish a novel which nobody would buy, because the people are too poor, too illiterate, and too busy trying to stay out of the way of the police and the army to read. And of course you know why paper is scarce and expensive - because of the economic sanctions placed on our country. But forget all that. Say you found an indulgent publisher to publish your book, someone who believes in this great book as much as you do; and because you are sure your book is good, you'd want to enter it for a competition - and what is the most obvious competition for someone from a commonwealth country? Of course, the Commonwealth Literary Prize. But you can't do that. (192)

Following James' sober and disillusioning monologue, a disquieted Lomba demands to know why he would not be able to enter his prospective novel for an international literary prize, and James adds a final, devastating dénouement: "Because Nigeria was thrown out of the Commonwealth earlier this morning. It was on the BBC" (192).

The political urgency of the moment, of the impossibility of inaction, is heavily underscored by James' apologetic but apt, sober and concluding understatement: "you can't write with chains on your hands" (193). Those metaphorical chains foreshadow the possibility of real chains as exemplified in the metal paraphernalia of slavery, which 
James points out to Lomba at the Slavery Museum in Badagry where he takes his ward for a harsh lesson in history, and social responsibility. The message was clear: political inaction would be tantamount to slavery under the corrupt and repressive dispensation.

While the theme of WFA is self-anthopologising and aligns with the exotic parameters for global canonical consecration of African literature, it is simply an honest depiction of a political moment, even if that moment confirms the general Western public's stereotypes about Africa as uniformly symbolising crisis. Nevertheless from a close reading of the work I argue that it entered the global canon for literary merit in the main, even if its anthropologising aspects enhance its flow into the circulation of world literature. An example of Habila's nuanced verbal skills and narrative dexterity are evident in the short story, "The Angel," from which the UK edition of the book derives its title.

That story describes an encounter between a citizen-protagonist, who had been foretold his death, and agents of the brutal state - soldiers - during a curfew. The suicidal willingness with which the protagonist anticipates and actually seeks his death symbolises the hopelessness of life in Nigeria under military dictatorship. The overall premonition of doom foreshadowed in the story's terse opening - "today is the last day of my life. I knew it when I woke up in the morning to find a crow croaking on my window ledge" (37) - reaches its climatic resolution as soldiers in a bar attack him later. It is the magic realist rendering of his assumed demise, which highlights an experienced writer at work:

My movement is too fast for the soldier because he isn't expecting it. In one motion I shove the table at him; the edge catches him in the stomach, knocking 
the gun out of his hands [...]. I made a desperate run for the door but before I reach it I hear a warning bark: stop or I shoot. It is the other soldier. But when I turn it is not a soldier standing there. It is an angel. It opens its enormous wings and closes them again in a clapping motion. The air from the wings lifts me up and carries me out through the door. I land with a splash on the wet street. I am bleeding from the chest. I feel life draining out of me - through the haze I make out a huge bird shape flying out of the bar and ascending with the sound of a thousand wings. Then it is gone. (44)

In order to distinguish it from texts which pander to the exotic, it is important to emphasise that WFA is an example of a text of great literary merit. In terms of its literary language as exemplified above it can be said to be worthy of being canonized as world literature based on that literary value alone, irrespective of its unwitting selfanthropologising qualities. These are clearly in evidence, and especially underscored by Nigeria's narrative moment of political crisis.

Specifically the narrative moment I refer to - in that extra-textual world overtly emphasised by WFA - is that of Nigeria's global disgrace within, and isolation from, the international community in the 1990 s due to the incumbent head of state, Sanni Abacha's, authoritarian and despotic regime. The dystopic world created by that government enlarged the stereotypes of an Africa of ravages and crisis in the global media and public. For a Western imaginary saturated with negatively unbalanced images of Africa on a daily basis, WFA simply confirms stereotypes about the continent generally and Nigeria specifically - even if the novel's realism is simply true to a particular narrative moment. Moreover that narrative moment is intensified by WFA's 
dexterous manipulation of the time of narration through a mostly first person point of view heightened in places with the simple present tense, all emphasised by a deliberate concluding social commentary at the end of the novel as postscript. It stridently underlines the urgency of the dystopia in the postcolony.

WFA's narrative comingling of fact and fiction results in a time of narration coincident with one of Nigeria's narrative moments as reflected in recurrent simultaneity with events unfolding in extra-textual calendrical clock time in the real. This is so palpable that 'momentary' dystopia is trapped as a perennial existential condition especially in the Western imaginary - to such an extent that a fictional 'once-upon a time,' or 'then,' implicit in reader response is suspended for a very urgent and immediate 'a minute ago,' 'right now' or 'simultaneously' (in text and world). This is the kind of narrative moment typical of strategic exoticism, and it ironically helps WFA escape the suffocation of the local retrieval canon vis-à-vis global canonisation, unlike other equally well-written texts, which even if also published in a literary capital still remain 'buried' or 'hidden.' Particular reference is to Ike Oguine's A Squatter's Tale (ST) (2000), and Okey Ndibe's Arrows of Rain (AR) (2000), both published by Heinemann International's African Writers Series in its waning years.

I have not been able to find any major critical essays on either of these two works in Research in African Literatures or any other major journal on African literature despite their having being issued by major multi-nationals. Apart from passing remarks about the works by scholars of the third generation, the occasional review of AR in Wasafiri (see "Forty Years of Publishing" 2003: 170), another review of both works in English in Africa (Raji "Identity and Narrativity" 2005: 143-148) or a listing of the authors' names 
as members of the new generation - 'retrieved in an ethnic instance as, more importantly, 'igbo' writers (Nwakanma "Methonymic Eruptions" 2008:4) - I am yet to encounter a serious scholarly engagement of these works.

One could argue that the above authors' invisibility might be due to the fact that their novels were published by local Nigerian subsidiaries of Heinemann publishers and were not re-issued in literary capitals. However the prelims of the works clearly state Oxford, and Portsmouth, New Hampshire as place of publication for Ndibe's book, and Oxford and Chicago for Oguine's. I can only conjecture that circulation was probably targeted more at an African rather than a global market - especially at the local school culture's curricular. Moreover in 2000 when both works were published, Heinemann was going through a transition that finally led to the demise of the African Writers' series by 2002 (Clarke "Forty Years of Publishing Series" 2003). As I have mentioned earlier a concatenation of causes and effects rather than any one single factor results in the phenomenon of the hidden text.

\section{Hidden Texts and Invisible Chapters}

Apart from their confirmation that multinational publishers in literary capitals can also produce hidden texts or that there is also such a thing as a metropolitan retrieval canon, a discussion of ST and AR's canonical marginalisation within in the metropolis fits into the general pattern of any otherwise promising Nigerian third generation text which might become buried mostly by local and sometimes by metropolitan retrieval canons especially in the case of genres other than fiction.

Poetry and drama, for example, are not a major concern in global or local publishing as a source of revenue. I have discussed the market imperatives of the book industry above in chapter two. Allan Hill's (1971) account of the beginning of 
Heinemann's African Writers Series shows clearly that profit was the major concern in deciding in what genre to invest. Further, Low reports Geoffrey Faber's capitalist philosophy, which causes the latter to insist that, "publishing is a business, and like all other businesses must be made to pay" (2006:19). We can also recall Alfred Knopf's desire to make Doris Lessing racialise the narrative strategy of "The Grass is Singing" in manuscript form. This was with a view to increased revenue deriving from a sensationalised text (Graham op. cit 203:433ff). Clearly metropolitan and local publics prefer reading fiction ahead of poetry or drama, and such it is this genre that is the major focus of canon forming mechanisms.

For example, the African poetry genre circulates mostly on academic curricula and peripherally within African national canons, retrieval or otherwise, despite the foundational early $20^{\text {th }}$ century importance of Anglophone and Francophone poetry and drama in the decolonising emergence of modern African literature, with the additional weight of guerrilla theatre in South-Africa's anti-Apartheid struggle. The case of Biyi Bandele-Thomas' dramatic successes in the UK or Helen Oyeyemi's occasional play are too insignificant to make allowance for any overall difference or impact. While BandeleThomas has staged successful plays it can be argued that his literary reputation was built on the fiction he wrote before he branched out into writing plays and theatre production, while Helen Oyeyemi's consecration depends on her three novels to date, irrespective of a published but largely unsung play, Juniper's Whitening and Victimese (2005). African poetry and drama published in the metropolis recede quietly into an invisible metropolitan retrieval canon - retrieval in the sense that they can be 'claimed' as part of a migrant Nigerian or African canon but are not recognised 'publicly' (even if marginally 
acknowledged in academic circuits) while they proliferate in the periphery as a permanent unrelenting portion of local retrieval.

While fictional works like Habila's WFA and Nwuabani's I Do not Come to You have escaped local retrieval based on their different narrative strengths and authorial strategies, some otherwise promising material like Maik Nwosu's Invisible Chapters (2001), Adesokan's aforementioned Roots in the Sky (2004), Dulue Mbachu's War Games (2005), Jude Dibia's Walking with Shadows (2005) and Unbridled (2007) are buried in Nigeria's local retrieval canon due mostly to poor reception, which in turn can be said to be due to several factors, chief amongst which is the lack of that universal acclaim usually initiated by consecration from a metropolitan literary prize and other forms of institutional validation.

The contention that Adesokan and Nwosu are promising writers bears a qualification - namely that any such 'great expectations' are based on the hope that their lofty visions will find a corresponding and heightened future craft, suggested but missing in their present works. While they have not won international literary prizes it is necessary to emphasise that metropolitan global canonical exclusion, as previously suggested, is not dependent on such awards alone, but that it is rather based on a complex of interlinked factors, including literary quality or the lack of it - in which case strategic exoticism alone might be raised above literary value as obtains, arguably, with I Do not Come. It is simply that the international literary prize is the most important of that consecrating complex due to its accompanying acceleration of international reception. The operation of that complex is emphasised in the genre preferment for global canonisation - the novel. In other words, in a hypothetical situation where the dramatic 
piece or a poetry collection wins an international prize would not translate into such works' entrance into popular reading consciousness even if it makes a marginal entry into metropolitan school curricula. The moral is that the novels mentioned above are hidden texts not so much because of poor quality or lack of excellence as due to a combination of factors, which result in metropolitan canonical invisibility. For example Invisible Chapters' lack of a sensationalising strategic exoticism aids in its metropolitan canonical invisibility. Although it does have estranging qualities, they are largely dystopic rather than being the ideological design of strategic exoticism.

Although Invisible Chapters, like a purely self-anthropologising novel such as I Do Not Come, addresses the realistic, such realism is not melodramatic: narration proceeds in a sober rather than stereotypical, sensationalising mode as in some strategicexotic works. The subject of Invisible Chapters is the early-1990s Nigerian government's demolition of a sprawling densely populated local slum, Moroko, in Lagos towards reclamation of land for real estate development by the rich without any serious relocation plans for the displaced and dispossessed. This is realistic and factual enough. In Nwosu's hands its fictionalisation is not in the strident, neurotic terms typical of strategic exoticism where a negative but fictional narrative mise en scène is transposed unto and becomes a stereotype for the real or a synecdoche for all of Nigeria or Africa's social space.

In Invisible Chapters there is a consciousness that the reader is in the presence of the fictional and it is possible to suspend disbelief in a hermeneutics of faith, while in the classic strategic exotic work it is the anthropological imperative and a sense of ethnographic 'discovery' that pervades, resulting in a hermeneutics of suspicion or of 
disquiet (for the discerning critic). In the instance of Nwosu an objective narrative mode does not help the novel in global canonical terms - nor does its exaggerated style.

Nwosu's Invisible Chapters is stylistically ambitious even with, and because of, its legion of characters, who are on the fringes of society in physical looks, in their names, and in literal and symbolic terms. The multiple narrative perspectives which such colourful and subversive characterisation proffers on the question of official injustice and civil impoverishment by the Nigerian state would have been more evocative if it were as a result of sustained plot, and novelistic speech rather than of exaggerated, philosophising 'platonic dialogue.' Here are two of the characters, Haile and Prinzi in conversation on the novel's theme of civil dispossession and impoverishment:

"Talk, talk," said Haile. "We should be coordinating some sort of reaction - a deafening shout across the wall."

"What sort of reaction do you propose, Haile? The mistake intellectuals make is the assumption that the people are incapable of carving their own resistance masks. Look at what happened in Bakalori. A village of farmers and fishermen stood up, although unsuccessfully in the end, against a government plot to dam the natural flooding that was their vital life support system."

"I trust you to cite a thousand instances if need be. But this is the time for action, Prinzi."

"I am a writer, my friend, not a hunter or sniper."

"What logic! Why have you never said: 'I am writer, not an entrepreneur'? Look, Prinzi, a writer is also an activist..."

"That's the point. A writer is essentially an activist by virtue of his striving to refine the sensibilities of men. If people truly paid heed to the lessons of literature..." 
"That's the real point. What if they don't and the basic condition of humanity is threatened?"

"Every revolution has its stages and usually the vanguards are the writers and the social philosophers who create images of the spirit in ascent. The writer does have a role to play. As a citizen, he also has a role - and he should play it, to the best of his ability. But being a writer does not particularly qualify anyone to lead a street march, if he isn't street wise and brave enough." (77)

I have quoted this exchange in detail to contextualise the intellectualising that Nwosu engages in rather than have characters' ideas be embedded in the plotting and acted out as lived experience within the moral universe of the novel.

The intellectualising of Invisible Chapter's theme is more self-conscious and artificial for its poetic, discursive or philosophical allusions. It is noteworthy that Nwosu is first and foremost a poet, having already published the poetry collection, Suns of Kush (1996) before engaging the novel form. In the passage above Haile's "a [...] shout across the wall" echoes the title of a poetry collection by the third generation poet, Idzia Ahmad Carlos, A Shout Across the Wall (1988). The last part of the above quotation referring to how 'every revolution has its stages and writers are its vanguards' echoes Frantz Fanon's thesis on the Third World subject's duty to self-regeneration in The Wretched of the Earth (1963). This over-philosophising in the novel form might then explain the novel's tortuous syntax and, sometimes, hyperbolic and exaggerated diction. This does not make for easy reading:

In his early years of settling there, not much was heard of Ashikodi - who, like Haile, had also studied History but who, unlike him, had earned a degree. He had busied himself establishing a livestock farm, and it was not until he had nurtured it to the point of 'farming' out the management that he was 
manifested into the trouble "troubler of Coconut Island", as he was sometimes rather fondly described because of his idiosyncracies. (7)

Above, the recurrent deployment of the past perfect tense ('had') and in such close proximity gives a 'heavy' archaic feel to the passage. The long second sentence, with its excessive punctuation, worsens that heavy feel, while "manifested into" is a strange usage that could have been more simply expressed. The simple past tense would have made the passage less cluttered. The overall effect is that of a syntax which impedes plot, and the reading process. That impediment is heightened by the application of the platonic dialogue for speech.

As deployed by Nwosu, the platonic dialogue, which John Dryden believes is a "distinctive artistic method of academic philosophy" (Monk and Maurer Works of John Dryden Vol. 17, 1971: 349), makes for heavy, sluggish reading within the novel genre, and is more suitable for the play as elaborated in Dryden's critique of that form vis-à-vis dramatic verisimilitude (An Essay on Dramatic Poesy 1668). ${ }^{112}$ Platonic dialogue in Invisible Chapters renders it so contrived that it hinders the narration and plot rather than extends the story line. The novel lacks verisimilitude, assumes an academic, moralising, preachy aspect and becomes didactic; the impression is one in which the author expresses the right ideas in the wrong form. If rendered as a dramatic or an essayistic piece, perhaps, Invisible Chapters would have achieved its intended effect, which is to satirise social injustice. Nevertheless its weakness is also its redeeming feature - that ambitious marrying of the technical aspects of drama, that is, its characterisation techniques and, novelistic plot. If the novel has structural limitations its ideological vision and sublime

\footnotetext{
${ }^{112}$ See also the commentary on "An Essay of Dramatic Poesy" in Complete Works of John Dryden 17 (California UP, 1971: 344ff).
} 
reaches save it from the merely pedestrian - but only if the reader perseveres in the first instance, despite the opaque text.

However, it can be argued that Invisible Chapters is a hidden text in global terms not so much due to its technical faults - which are obvious enough - and its realistic narration devoid of sensation as because of its place of publication in the main, and due to a host of factors as I have argued is the case with the retrieval canon. Place of publication, print run, level of dissemination, publisher's institutional clout or prestige and other factors would have worked together to restrict the velocity of this travelling text from its local point of origin. Its non-strategic-exotic narrative style eschews concerted international reception and consolidates its invisibility. In other words it did not really truly arrive in metropolitan critical circuits even if its technical weaknesses would have limited it to a metropolitan retrieval canon in such a case. In actual fact its lack of a selfanthropologising theme, or a sensationalising mode of narration, does act to further limit it. As such Invisible Chapters is 'shelved' as part of the 'dusty archive' of contemporary Nigerian, and African, novels in the global retrieval canon through a mere twenty-one global library holdings on the world catalogue data bank. This figure has remained constant over the period it took me to complete this dissertation.

Of symbolic import to the discussion of retrieval and the phenomenon of the hidden text is Invisible Chapters' subtext. I refer to that meta-narrative commentary on, and reference, to the act of writing and publishing - as figured in a writer-protagonist exemplified through Lomba in WFA and through Prinzi in Invisible Chapters. Such meta-narrative anxieties are co-terminus with larger textual and extra-textual social and existential conditions of desire and lack. Prinzi's desire to write and publish cannot be 
divorced from the liberating purposes and political agency to which he hoped to press the text on behalf of the beleaguered, oppressed, displaced and poor citizenry of Maroko slum, who are being ejected from that land to benefit the rich.

The existential distractions and difficulties which - coupled with an apparent lack of raw talent and a permanent writers block - hinders Prinzi from progressing from mere desire to the physical act of actual writing, and finding publishing outlet, is reflective of the difficulty of the dispossessed in ever hoping to receive just redress in Invisible Chapters. "Prinzi's claim to being a writer lay in a sole short story he had [sic] written, which had [sic] been published in a local newspaper" (5). Maroko itself is consistently compared to a text or is textualised: "I don't know about you, but I am here [i.e. in Maroko] because Maroko is the new novel of the future - a masterpiece awaiting a Prinzian craftsman" (73). In reference to the dehumanising absurdities pervading the lives of the inhabitants of Maroko - such as pastor David's profiting from the poverty of the slum dwellers (73) - Prinzi comments that such ironies exemplify the "great Maroko novel $[\ldots]$ practically writing itself" (85). Nevertheless, he does not actually ever write that masterpiece; its chapters remain invisible. This futility is emphasised when Prinzi offers a desperate semblance of a book - a bound but 'empty' only copy - to Ashikodi and Segi as a wedding present towards the end of the novel:

Finally Prinzi got the opportunity to present his book. There was only one copy - ' a special wedding present to a special couple on a special occasion in the life of New Maroko: the seemingly invisible chapter of dreams at work.' Apart from the cover page, the content were three hundred blank pages and a 
seven-paragraph appendix entitled 'in the beginning ...RFA: Revised First Attempt $[\ldots](266)$.

The unrealised desire for a magical text or Über-narrative, which will write away the social injustice and initiate agency for the oppressed is symptomatic of the perpetual existential lack that is the portion of the masses of a Maroko, which is archetypical of Nigeria.

While textually the failure of Prinzi, the writer, is the failure of the Nigerian intellectual class, the meta-narrative subtexts of the work have important extra-textual ramifications for cultural production. Third generation writers in a continent whose history is circumscribed by desire and lack are trapped in a disabling existential present such that cultural production becomes an example of such dialectical play of desire and lack. The result is that these writers are self-conscious of the creative process, possibilities and impediments, and they position themselves 'deliberately' within the field of cultural production due to a consciousness of such material conditions of lack. It is against such a background that the meta-narrative of cultural production in WFA and Invisible Chapters becomes symbolic of larger and urgent extra-textual existential conditions. Lomba in the former and Prinzi in the latter are alter egos of the authors themselves, and these characters' anxieties over their ability to write and publish reflects that of the authors over the fate of their works and 'global' reception to them.

Like WFA, Invisible Chapters is a meta-narrative about literary production and dissemination, where the text as 'writing' is a self-reflexive act. It displays an anxiety over the possibility of its ending up in the local retrieval canon, on the one hand, and over the likelihood of not achieving its goals of social agency, on the other. Just as the slum 
dwellers' lives are invisible chapters, a tabula rasa, not worthy of official attention but its corrupt inscriptions, so is the text itself an 'invisible chapter' on the fringes of the local retrieval canon, and for its being ignored by global readership. But more immediately, it is an invisible chapter because Prinzi hardly actually has a bound book with only a title and no content - it literally contains invisible chapters. By the time he begins to fill out those empty chapters at the end of the novel, we cannot be sure that he will ever finish or actually write more than the few paragraphs we read. The textual anxiety of the novel symbolises the anxieties of the contemporary African writer over cultural production and dissemination, their desire to produce and a lack of the material condition and infrastructure of/for dissemination. The retrieval canon, where the novel, Invisible Chapters, becomes invisible as a physical object and fulfils the prophesy of its title, constitutes this lack.

Third generation novels invariably exhibit the same textual and extra-textual anxieties to be found in Invisible Chapters to a large extent or WFA to a lesser degree. That is apparent in their self-consciousness and stylistics and thematic preoccupations. Other third generation works become invisible chapters in global canonical terms due to their textual narcissism. Another example, which needs some commentary due to its textual anxieties, is Akin Adesokan's Roots in the Sky. Its esoteric and serpentine prose leaves meaning behind as it snakes ahead of the reading process. Here is the novel's opening paragraph:

He came back a sick man. And today, just at dawn when I began writing this after three weeks of hiding have merely made us more vulnerable to arrest or murder, one is no surer of the fate of Nyaze than one can be of Nini's, his lover 
from our days of endless privation, whose desperation (or whose mistake if we remember the pregnancy), drove him away in the first place. It was raining the night Nyaze, also known as Dada, and called Filatei, returned without a warning, coming through the door with the haunting, odd look of the manalone. (7)

The tortured syntax displayed above is regular fare in Roots in the Sky. It shares Invisible Chapters' ponderous, academic, essayistic feel, which makes the work appear contrived and destroys verisimilitude. Moreover Adesokan's English equivalences of Yoruba verbal complexities and de-contextualised transliteration of Yoruba mytho-poetics (2733) further render his prose inscrutable.

Nevertheless, as in Nwosu's work, Adesokan's sublime thematic preoccupation is a saving grace. This however does not rescue either work from a phenomenon I refer to as their 'unreadability' in borrowing from J. Hillis Miller's (1980) rather positive deployment of that concept to capture the semantic wealth of Henry James's signature narrative technique as exemplified in the story, "The Figure in the Carpet" (1896), where through allegorical force the field of signification is so infinite that meaning becomes inexhaustible. Predictably I, however, apply the term 'unreadability' in quite an opposite sense to Miller's and in a near-denotative understanding of it in relation to Roots in the Sky and Invisible Chapters. The universal agreement on Jamesian semantic inexhaustibility engendered by a debate in poetics today (1980/1981) and captured in the term unreadability is nowhere visible in the two works under discussion. Rather what obtains in them is quite the opposite - a semantic contraction due to a dissonance 
between form and content, which is inimical to, and emphasises the concept, of unreadability as semantic inexhaustibility as discussed by $\operatorname{Miller}^{113}$.

To further underscore unreadability in contemporary Nigerian fiction it is necessary to highlight an extreme example of it. Sanya Osha's Naked Light and the Blind Eye (2010) is a loftily conceived but poorly delivered third generation novel, whose sudden opening is an abstract mourning of a sour relationship:

She had gone. Just like that. But that wasn't what bothered me in the immediate sense [...]. I am almost sixty and night is the breeze before me. It hadn't been like this for me as a young man. I had plans. And I had ideals. After several hesitations I had resolved to be a word, and like every word that passes from mouth to mouth, I wanted to move from my etymological locus through one age to another, gathering different meanings and usages until I realised at least the limits of my boundaries and then invented for myself possibilities beyond my immediate range. I had hoped to be a whole race, an infant, a grown man (which is what I actually am), a grown female, pulling through a gamut of experiences and manifestations along the way. Sometimes I had hoped to deliberately refuse to shift my myriad social interactions to enjoy the beauties of ambiguity, the sole mystery behind the thoroughly poeticised experience. Lyricism immediately connotes the fluidity of oceans and rivers. It celebrates the labyrinthine mazes of meaning. The supreme feminine form that undresses itself with perfumes in a nocturnal continent of

\footnotetext{
${ }^{113} \mathrm{~J}$. Hillis Miller's unreadability is echoed by Tzvedan Todorov's reference to Henry James'es oeuvre as having a rich central metaphoric narrative technique of a 'present absence' and 'endless quest' or 'secret' in "The Structural Analysis of Literature" (1989: 901). Miller's analysis is in conversation with Shlomith Rimmon-Kenan's theory of "ambiguity", in the sense of a richness, expressed in her formula " ' $a$ ' and 'not a" "(The Concept of Ambiguity, 1977 qtd. in "A Guest," Miller 1980/81: 190).
} 
satin was the ultimate image I pursued. This was my ambition, to be beyond the frustrations and abuses of a stark reality that bleeds the language of life, of its mobility, and then eventually robs it of all poetry. (1ff)

The novel opens and progresses in this abstract ${ }^{114}$ and long-winded manner. The above passage as it stands is poor form straining after sublime content in a similar fashion to Invisible Chapters and Roots in the Sky.

Moreover Sanya Osha's unreadability is compounded by actual physical constraints to the reading eyes due to technical and editorial infelicities. The text deviates poorly from the standard font size and typography for prose fiction. Lines are singlespaced and almost merging into each other and uncharacteristically justified in the left hand margin instead of the right. Paragraphs are not indented, and are demarcated with only a double space between them. Speech is not properly identifiable through the right typography or quotation marks as such and there is no textual indication that it is a deliberate stylistic innovation. The overall visual impact is discouraging and aids the work's unreadability in a very literal sense.

I have consistently suggested that a work's confinement to a local or global retrieval canon is never due to a single or a few reasons but to a concert of the forces of literary production. Though Osha's work is published in the literary capital of London, UK, it is not saved from the retrieval canon. However this might be due to the fact that a metropolitan publisher is not necessary reputable just for being located in the West. The

\footnotetext{
114 The Africanist critic, Chris Dunton's review of Sanya Osha's novel in Sahara Reporters notes this tendency for abstraction and opacity but rather glosses them to sift for some meaning out of the text. Nevertheless the incongruous placing of this review in a news magazine rather than in a serious scholarly peer-reviewed journal is probably an indication of what the critic really feels about the work. See: < http://saharareporters.com/art-life/sanya-osha-naked-light-and-blind-eye $>$
} 
technical quality of the novel suggests that its publisher is a glorified printer, who does not understand due editorial process. In the first instance such a publisher would have rejected the manuscript in the form it was in before the book was issued.

It is curious and significant for the processes of local retrieval - in its overlapping with metropolitan retrieval - that these three texts under discussion all won the Association of Nigerian Authors' prose prizes at different times in manuscript form despite their unreadability. This unusual situation is attributable to that already discussed moment in Nigerian literary history where a combination of economic erosions, the dearth or inadequacy of publishing infrastructure and a perennial lack of public funding for the arts led to the institution of the Association of Nigerian Authors and its annual prose, poetry and drama prizes, which is meant to harness new talent and encourage literary production. As discussed earlier that cultural scenario is in the background of the literary renaissance of the 1980 s. The unwitting side effect is a local retrieval mentality that is still prevalent but ignored by critics. Invisible Chapters, Roots in the Sky and Naked Light and Blind Eye were all recruited into a burgeoning local retrieval canon through the instrument - ironically - of the local literary prize, amongst other factors. While Osha's novel ought not to have been awarded a prize in its current form, I do not suggest that the first two works lack literary merit, but that as tentative efforts, they ought not to have been awarded prizes right away. This would have allowed the novelists to hone their craft and develop in a robust fashion.

Again, a combination of poor literary and editorial quality, circulation constraints due to place of publication and type of publisher, and local literary prizes of questionable integrity, all combine to limit some new works like those under discussion to circulation 
mostly within the periphery. In this way they are automatically shelved or retrieved in the metropolis as marginalia within the global library system and within metropolitan school culture. Nevertheless not all works in the retrieval canon are consigned there due to unreadability or a disadvantaged place of publication, ineffectual and vanity publishing or any of the other factors mentioned so far. The moral is that from work to work, a different concatenation of factors might lead to retrieval. Ike Oguine and Okey Ndibe's novels are good examples.

As suggested earlier, Oguine's $A$ Squatters Tale, and Ndibe's Arrows of Rain are quite 'readable,' based on their coherent plots, accessible diction, and verisimilitude. Ndibe's work is a dystopic allegory of the abuses of power in a fictional African State, Madia. Ndibe weaves an apparently simple story of murder and wrongful accusation into a complex tapestry of parallel plots ${ }^{115}$ implicating Madia's military dictator, General Isa Pot Bello, Ogugua, an eccentric citizen, the prostitute, Iyese, and Femi Adero, a journalist. It turns out that the murder of a prostitute at the beginning of the novel echoes a similar crime committed by the general and life president; that Ogugua who was privy to that initial crime kept silent for too long to disastrous consequences, that Iyese the prostitute and link between Pot bellow and Ogugua, was also Femi Alero's long-lost biological mother, making Ogugua Femi Alero's father. The semblance of a straightforward crime thriller at the start of the story develops into a complex political allegory of power abuse and misrule, civic irresponsibility, treachery, and identity crisis.

Nevertheless this very readable and stylistically successful novel has become a hidden text, considering its poor critical reception, lack of proper representation within

\footnotetext{
${ }^{115}$ In his review on Arrows of Rain in English in Africa (2005) Wumi Raji refers to its parallel plots as mega-narration, main-narration and sub-narration respectively (144).
} 
global school culture or amongst the global reading public. It is 'shelved' on metropolitan archives and unjustly restricted to the local retrieval canon. The same condition of disproportionately poor dissemination despite relative robust literary quality applies to $A$ Squatter's Tale.

Oguine's work is a tragicomic depiction of the misconceptions and illusions about exilic life. The 'tale' is that of the 'squatter,' Uncle Happiness, who on a brief visit to Nigeria, pretends to a life of affluence and glamour as an immigrant in America in the first part of the novel to impress the protagonist, an innocent ten year old nephew, Obi. Many years later, a gullible Obi immigrates to America as an economic refugee based on Uncle Happiness's earlier deceptions. Too late the newcomer discovers the sordid life and social displacement of his uncle's class of immigrants in America, a class to which the former unfortunately now belongs. The tragicomic figure is that of the ebullient Uncle Happiness, irrepressibly 'happy,' forever dancing away his sorrows, despite frustrations and an aimless life in America where dreams become living nightmares. Uncle Happiness' life can be summed up as one orgy of dancing, interspersed with frenetic but futile stabs at success, tear-soaked, drunken self-pity, unreasonable hopes of a brighter future, and more self-pity, which dissolves into unshed tears and sorrowful dancing.

Ideally, a humorous, satirical novel of solid literary quality about exile and dislocation like Oguine's, and Ndibe's simple allegory, with its complex plot, should both enter the canon of world literature. We should also especially consider that they are published in the metropolis by no less a transnational publisher than Heinemann in London. Nevertheless in keeping with my canonical arguments, a series of factors have worked together to render these texts hidden, chief of which is their non-self- 
anthropologising narrative strategies. Although $A$ Squatters Tale and Arrows of Rain address social malaise and existential problems in the postcolony, their narrative strategy does not sensationalise the subject as usually obtains in strategic exoticism. While, in all appearances, the works are published by a conglomerate like Heinemann, it can be argued that they probably did not enjoy the publicity and dissemination typical of that publisher due to operational streamlining preceding the demise of Heinemann's African Writer Series, under which imprint both novels were issued in 2000. The result would have been ineffective post-publication reviews and critical reception. The works were therefore quietly shelved in the metropolitan archive, and slipped into the local retrieval canon as hidden texts.

Both published in the year 2000 Arrows of Rain and A Squatter's Tale - in their silent arrival - are symbolic of the changing fortunes of transnational African publishing at the time. Heinemann, The two works' publisher were on the cusp of ending the African Writers Series imprint under which the books came out. Forty years of active an energetic publishing was winding down. In 2000 the atmosphere into which these two novels arrived was one of a consequent waning interest in African literature by metropolitan publishing establishments and their publics. These are some of the distant reasons for the decreasing metropolitan investment in African writing towards the end of the $20^{\text {th }}$ century, the immediate catalyst being the economic erosions attendant upon almost half a century of comprador and corrupt leadership since flag independence in the 1960s. By the time Arrows of Rain and A Squatter's Tale were published, Heinemann's African Writing Series was in a serious decline. The formal offer of Penguin Publishers to take over the 
series signalled its unofficial institutional demise (Clarke "African Writers Series" 2003:170) - at least under Heinemann's stewardship.

Again the significance of retrieval as refracted through a work's material conditions of production and dissemination vis-à-vis metropolitan circulation as distinct from 'canonization' can be exemplified in the fortunes of some notable new works within global instruments of circulation. Despite its having won the Nigerian Ken Saro-Wiwa prize for prose in 2007 and being shortlisted for the locally prestigious NLNG prize, Jude Dibia's Unbridled (2007) is held globally by just forty libraries in the world catalogue database, while five libraries stock his Walking with Shadows (2005). At a global holding of 11 copies by different libraries globally the circulation of Dulue Mbachu's War Games, a non-self-anthropologising novel on the Nigerian Biafra civil war compares very poorly with 1660 global listings for Chimamanda Ngozi Adichie's self-anthropologising Half of Yellow Sun in the Alfred Knopf edition alone.

It is clear that the phenomenon of retrieval can be metropolitan or local. What is common to all books, both hidden and visible texts is circulation - relatively speaking, and irrespective of the smallness of the receiving audience. Nevertheless circulation is not necessarily the same as canonization. While the international literary prize is usually a consecrating mechanism towards canonisation, it is not an incontrovertible proof of it. There are those third generation writers who have won some of these prizes and then quietly disappeared into a retrieval canon of sorts. Aribisala's Our Wives and other Stories, which won the Commonwealth prize in the UK, seems to have contracted in circulation. The online world catalogue has 106 holdings of it even though it was published in 1990, over 20 years ago. As some of the novels I have discussed prove, in 
most cases local literary prizes, emanating from disempowered literary spaces as they do, do not guarantee canonisation at all.

\section{Conclusion}

This study demonstrates that the inequality between the global North and the global South is resilient, in spite of neo-liberal notions of an all-inclusive globalisation. What appears to be a levelling of power relations - apparent in the disappearance of colonialism, and in freedom from direct political hegemony since the $1960 \mathrm{~s}$ - is simply a paradigm shift. The dynamics of power and domination has moved from old historical paradigms to the arena of culture. The Black Atlantic and Black Internationalist antecedents of African writing indicate that it has always existed on the margins of a grudging Western canon, which considered it suspect, or illegitimate. That suspicion has not diminished with the globalisation of writing; it was complicated by colonialism and did not disappear with independence. This is because the socio-cultural hierarchy constructed between African writing and the metropolitan canon has not been dismantled and is not likely to be very soon. That is irrespective of liberal views that emphasise the mutual benefits of "modern colonialism" (Nandy "Imperialism as a Theory" in Hamm and Smandych Cultural Imperialism 2005: 55), which "was the first serious, systematic effort at globalizing the world" (ibid.).

Of note, Frederick Buell's National Culture and the New Global System (1994) follows a recurrent postmodernist argument in proposing a moment of global interdependence, which should move beyond 'nationalism' and concentrate on modernism's mutual benefits for the West and the rest (Chinweizu 1975) in a hyperglobalised world. He interactively reads Ngugi wa Thiongo, Ashis Nandy and 
Frantz Fanon ${ }^{116}$ as constituting postcolonial nativist/nationalist critics whose leftist politics disavow a universally beneficial globalism. Arif Dirlik's (1996: 323-326) review of Buell's work in the Journal of World History (Vol. 7.2) critiques it as being ahistorical. Dirlik insists that "[t]he problem with [Buell's] argument, as with other such arguments inspired by a postcolonialism gone berserk, is its total dismissal of earlier ways of looking at the world, which in the end deprives it of any critical reflexivity. Buell's argument suffers from serious contradictions that he fails to address" (325).

Moreover, Amina Mama ("Is it Ethical to Study Africa" 2007) thinks that: "Africa is perhaps the continent of globalization's deepest discontents" (3). She questions the logic of a global cultural industry, which largely ignores the knowledge (read literary) production of a "continent of fifty three [sic] nations and over eight hundred million people" (3). She refers to Zeleza's (2003) Rethinking African Globalisation in maintaining that "[t]he marginalization of Africa within the world order is echoed in the global knowledge arena" (4). This has relevance if we consider that African writing is only one aspect of a continental intellectual production, of which knowledge production is part. The reason for a marginalisation of African cultural production in spite of the demise of historical colonialism is the resilience of dependency.

That fact, in itself, seems obvious enough, nevertheless it takes on urgency when refracted through the Latin Americanist concept of "coloniality" (Quijano "Coloniality of Power" 2000), which is "the invisible and constitutive side of [a] modernity" (Mignolo, 2007: 4) responsible for dependency in the first place. The relevance of colonoliality is

\footnotetext{
${ }^{116}$ Frederick Buell critiques the following works of these authors as displaying a need to move beyond 'victimhood' or as being symptomatic of the intolerance he critiques: Decolonizing the Mind (Ngugi 1986), The Intimate Enemy (Nandy 1983) and Traditions, Tyranny and Utopias (Nandy 1987), and The Wretched of the Earth (Fanon 1956),
} 
that even if colonialism is over, something much more insidious - because it is not easily recognizable as having the same cultural hegemonic effects as colonialism - is at work: coloniality. Biodun Jeyifo's "In the Wake of Colonialism and Modernity" (in Quayson and Tejumola ed. African Literature, 2007: 608ff) reads modernity and colonialism as constitutive of each other and synonymous, such that the transition from tradition to modernity can be assumed to carry the colonial in its being. The sense in which Jeyifo re-reads that intersectionality highlights the prevalence of Quijano's coloniality, which even though it is not historical colonialism - is performative of it in function and hides within Eurocentric liberal values like 'democracy', human rights, multiculturalism, (or even globalization) and so on, though we are not to discount their obvious benefits. According to Quijano:

What is termed globalization is the culmination of a process that began with the constitution of America and the colonial/modern Eurocentered capitalism as a new global power. One of the fundamental axes of this model of power is the classification of the world's peoples around the idea of race, a mental construction that expresses the basic colonial domination and pervades the more important dimensions of global power, including its specific rationality: Eurocentrism. ("Coloniality of Power" 533)

The marginalisation of African literature within the global literary canon is possible only because of the workings of a coloniality, which suggests that the term 'dependency' is still relevant today and should retain the 1960 s and 1970 s' understanding of its socioeconomic, cultural and politically subordinating imperatives (Tétreault and Abel Dependency Theory 1986). 


\section{Bibliography}

Achebe, Chinua. The Trouble with Nigeria. London: Heinemann, 1983. Print.

---. "An Image of Africa: Racism in Conrad's 'Heart of Darkness."' Massachusetts Review, 1977:18. Research in African Literatures Vol. 9:1. Special Issue on Literary Criticism (1978): 1-15.

---. Things Fall Apart. London: Heinemann, 1958. Print.

Adam, Hazard "Canons: Literary Criteria/Power Criteria." Jstor. Critical Inquiry14. 4 (1988): 748-764. Web.

Adebanwi, Wale. Trials and Triumphs: The Story of The News. Lagos: West AfricanBook Publishers, 2008. Print.

Adesanmi, Pius and Dunton, Chris. Eds. "Nigeria's Third Generation Writing: Historiography and Preliminary Theoretical Considerations in English in Africa 32.1 (South Africa: Rhodes, May 2005): 7-19. Print.

Adesanmi, Pius "Third Generation African Literatures and Contemporary Theorising." The Study of Africa vol. 1 Paul Tiyambe Zeleza (Senegal: Codesria, 2006): 101-115.

---. "Colonialism, Ecriture, Engage, and Africa's New Intellectuals." The Dark Webs of Remembrance. Toyin Falola. Ed. (North Carolina: Carolina Academic Press, 2005): 269-285.

---. "Redefining Paris: Trans-Modernity and the Francophone African Migritude Fiction" Modern Fiction Studies 51.4 (2005): 958-975.

--.. "Reshaping Power and the Public Sphere: The Political Voices of African Writers" in Reframing Contemporary Africa: Politics, Economics and Culture in the Global Era. Peyi Soyinka Airewele and Rita Kiki Endozie Eds. (2010): 258-274.

---. "Europhonism, Universities and Other Stories: How not to Speak for the Future of African Literatures." Palavers of African Literature: Essays in Honor of Bernth Lindfors. Eds. Toyin Falola \& Barbara Harlow. Trenton, NJ,: Africa World Press (2002): 105- 136. Print.

Adesokan, Akin. Roots in the Sky; Lagos: Festac Books, 2004. Print.

---. "New African Writing and the Question of Audience." Research in African Literatures 43.3 (2012): 1-20. Project MUSE. Web. 12 May. 2013. 
Adichie, Chimamanda Ngozi. Purple Hibiscus: New York: Anchor Books. 2004. Print.

---. Half of a Yellow Sun: New York. Knopf: 2006. Print.

--.. "African 'Authenticity' and the Biafran Experience." Transition 99 (2008): 42-53. Print.

---. "The Danger of a Single Story." Ted.com. 2009. TedTalk Lecture Series. $<\mathrm{http}: / /$ www.ted.com/talks/chimamanda_adichie_the_danger_of_a_single_story.html $>$.

Afolabi, Niyi. Marvels of the African World: African Cultural Patrimony, New World Connections, and Identities. Trenton, NJ: Africa World Press, 2003. Print.

Ajayi, J. F. Ade. Christian Missions in Nigeria, 1841-1891; the Making of a New Elite. Evanston [IIl.]: Northwestern UP, 1965. Print. Ibadan History Series.

Ajibade, Kunle. Jailed For Life: A Reporter's Prison Notes. Ibadan: Heinemann. 2003. Print.

Althusser, Louis. Lenin and Philosophy, and Other Essays. New York: Monthly Review P., 1971. Print.

Amoko, A. O. "The Problem with English Literature: Canonicity, Citizenship, and the Idea of Africa." Jstor. Research in African Literatures 32.4 (2001): 19-43. Web.

Amuta, Chidi. The Theory of African Literature; Implications for Practical Criticism. London: Zed, 1989. Print.

Amuwo, Kunle. Federalism and Political Restructuring in Nigeria. Ibadan, Nigeria: Spectrum Books: IFRA, 1998. Print.

Anderson, Benedict R. O'G (Benedict Richard O'Gorman). Imagined Communities: Reflections on the Origin and Spread of Nationalism. London: Verso, 1983. Print.

Appadurai, Arjun. Modernity at Large: Cultural Dimensions of Globalization. Minneapolis, Minn: University of Minnesota Press, 1996. Print. Public Worlds v. 1.

Ashcroft, Bill, Gareth Griffiths, and Helen Tiffin. The Empire Writes Back: Theory and Practice in Post-Colonial Literatures. London: Routledge, 1989. Print. New Accents.

Ayandele, Emmanuel Ayankanmi. Educated Elite in the Nigerian Society. Ibadan: Nigeria, U. P., 1974. Print.

---. The Missionary Impact on Modern Nigeria, 1842-1914: A Political and Social Analysis. London: Longmans, 1966. Print.

Anyanwu Chris Ngozi. The Days of Terror: A Journalist's Eye-Witness Account of 
Nigeria in the Hands of its worst Tyrant. Ibadan: Spectrum Books, 2002. Print.

Baker, Pauline H. "Lurching toward Unity." Jstor. The Wilson Quarterly (1976-), 4.1 (1980): 70-80. Web.

Barber, Karin, and Graham Furniss. "African-Language Writing." Research in African Literatures 37.3, Creative Writing in African Languages (2006): 1-14. Print.

Barber, Karin. "Time Space and Writing in Three Colonial Yoruba Novels." The Year Book of English Studies Vol. 27. The Politics of Postcolonial Criticism (1997): 108129. Web.

---. "African-Language Literature and Postcolonial Criticism." Research in African Literatures 26.4 (1995): 3-30. Print.

Bayart, Jean-Franøcois. The State in Africa: The Politics of the Belly. London; New York, N.Y: Longman, 1993. Print.

Beidelman, T. O. (Thomas O.). Colonial Evangelism: A Socio-Historical Study of an East African Mission at the Grassroots. Bloomington: Indiana University Press, 1982. Print.

Benjamin, Walter. Illuminations. [1st ed.] ed. New York: Harcourt, Brace \& World, 1968. Print.

Bentahar, Ziad. "Continental Drift: The Disjunction of North and Sub-Saharan Africa." Research in African Literatures 42.1 (2011): 1-13. Project MUSE. Web.

Beti, Mongo. Mission to Kala. Translated from the French, by Peter Green. London: Heinemann, 1964. Print.

--.. The Poor Christ of Bomba;. London: Heinemann, 1971. Print.

Blanchard, Pascal. Human Zoos: Science and Spectacle in the Age of Colonial Empires. Liverpool: Liverpool University Press, 2008. Print.

Bhola, H. S. "An Overview of Literacy in Sub-Saharan Africa." African Studies Review. Vol. 33. 3, 1990. Special Issue for the International Year of Literacy. Web.

Boehmer, Elleke. Colonial and Postcolonial Literature: Migrant Metaphors. Oxford; New York: Oxford University Press, 1995. Print.

Booth, James. Writers and Politics in Nigeria. London: Hodder and Stoughton, 1981. Print. 
Bourdieu, Pierre, and Randal Johnson. The Field of Cultural Production: Essays on Art and Literature. New York: Columbia University Press, 1993. Print.

Buell, Frederick. National Culture and the New Global System. Baltimore: Johns Hopkins University Press, 1994. Print. Parallax.

Bulawayo, NoViolet. "Hitting Budapest." Web. 20 Oct. 2012. $<$ http://www.bostonreview.net/BR35.6/bulawayo.php>.

Buxo, African Writers Series and the Development of African Literature Harvard U: PhD Thesis, 1998. Print.

Cary, Joyce. Mister Johnson. London, Joseph:, 1947. Print.

Casanova, Pascale. The World Republic of Letters; Cambridge, Mass.: Harvard University Press, 2004. Print. Convergences.

Chinweizu, Ihechukwu Madubuike, and Onwuchekwa Jemie. Toward the Decolonization of African Literature; Washington, D.C.: Howard University Press, 1983. Print.

---. The West and the Rest of Us: White Predators, Black Slavers, and the African Elite. [1st ed.]. ed. New York : Random House, [1975]. Print.

Cole, Teju. Open City. New York: Random House, 2011. Print.

---. Everyday is for the Thief. Abuja, Nigeria: Cassava Republic, 2007. Print.

Currey, James. "Chinua Achebe, the African Writers Series and the Establishment of African Literature." African Affairs 102.409 (2003): pp. 575-585. Print.

Damrosch, David. What is World Literature? Princeton, N.J.; Oxford: Princeton University Press, 2003. Print. Translation/transnation.

Dasylva, A. O. "'Culture Education' and the Challenge of Globalization in Modern Nigeria." Project Muse. Oral Tradition 21.2 (2006): 325-341. Web.

Davis, Charles T., and Henry Louis Gates. The Slave's Narrative. Oxford [Oxfordshire]; New York : Oxford University Press, 1985. Print.

Davis, Caroline. "The Politics of Postcolonial Publishing: Oxford University Press's Three Crowns Series 1962-1976." Project Muse. Book History 8 (2005): 227-244. Web

Diala, Isidore. “Migrating Bards: Writers' Burdens and a Writers' Body in Nigeria at 
the Turn of the Century." Web. 20 Aug. 2010. Tydskrif vir Letterkunde 45.2, 2008. $<$ http://www.letterkunde.up.ac.za/argief/45_2/10\%20Diala\%2003.pdfs.

Dirlik, Arif. Global Modernity: Modernity in the Age of Global Capitalism. Boulder: Paradigm Publishers, 2007. Print. The Radical Imagination Series.

.... "Global in the Local" in Global/Local: Cultural Production and the Transnational Imaginary ed. Wilson and Dissanayake. Durham/London: Duke UP, 1996. 21-45. Print.

Dryden, John. "An Essay of Dramatic Poesy" in Complete Works of John Dryden Vol. 17 USA: California UP, 1971. Print.

Dunton, Chris. Sanya Osha Naked Light and the Blind Eye. Saharareporters.com. Review. Web. 12 April 2012. < http://saharareporters.com/art-life/sanya-osha-naked-light-and-blind-eye>.

Dussel, Enrique. "Eurocentrism and Modernity (Introduction to the Frankfurt Lectures). Jstor. Boundary 2, Vol. 20.3. The Postmodernism Debate in Latin America (1993): 6576. Web.

Eagleton, Terry. Criticism and Ideology: A Study in Marxist Literary Theory. London: Verso., 1976. Print.

--.. The Idea of Culture. Oxford, UK; Malden, MA : Blackwell, 2000. Print.

---. Literary Theory: An Introduction. Oxford: Blackwell, 1983. Print.

--.. The Event of Literature. New Haven: Yale UP, 2012. Print.

Eaton, Mark A. "The Cultural Capital of Imaginary versus Pedagogical Canons." Project Muse. Pedagogy. 1.2 (2001): 305-315. Web.

Eburne, Jonathan P. (Jonathan Paul) and Braddock, Jeremy. "Introduction: Paris, Capital of the Black Atlantic." Project Muse. Modern Fiction Studies, 51.4, Winter (2005): 731-740. Web.

Ede, Godwin. "Song" in Voices from the Fringe. Harry Garuba. Ed. Lagos; London: Malthouse, 1988

Ede, Amatoritsero. "English in Africa." Review. Web. 05 Jan., 2008. $<$ http://www.sentinelpoetry.org.uk/1006/englishinafrica.htm>

Edwards, Hayes Brent. "The Uses of Diaspora." Jstor. Social Text 19.1 (2001): 45-73. Web.

Ekeh, Peter. "Colonialism and the Two Publics in Africa: A Theoretical Statement." Project Muse. Comparative Studies in Society and History 17.1 (1975): 91-112. 
Web.

English, James F. The Economy of Prestige: Prizes, Awards, and the Circulation of Cultural Value. Cambridge, Mass.: Harvard University Press, 2005. Print.

Fanon, Frantz. Black Skin, White Masks. New York,: Grove Press, [1967]. Print.

---. The Wretched of the Earth. New York: Grove P., 1963. Print.

Finkel, Donald L., and William Ray Arney. Educating for Freedom: The Paradox of

Pedagogy. New Brunswick, N.J. : Rutgers University Press, 1995. Print. Arnold and Caroline Rose Book Series of the American Sociological Association.

Foucault, Michel, and Colin Gordon. Power/knowledge: Selected Interviews and Other Writings, 1972-1977. 1st American ed. ed. New York: Pantheon Books, 1980. Print.

Frank, Andre Gunder, and Barry K. Gills. The World System: Five Hundred Years Or Five Thousand?. London; New York : Routledge, 1993. Print.

Freud, Sigmund. "Three Essays on Sexuality on the Theory of Sexuality." Ed. and trans. James Strachey. United States: Basic, 2000. Print.

Gallagher, Susan V. "Contingencies and Intersections: The Formation of Pedagogical Canons." Project Muse. Pedagogy. Volume 1.1 (2001): 53-67.

Gandhi, Leela, and Inc NetLibrary. Postcolonial Theory. Edinburgh: Edinburgh University Press, 1998. Print.

Garuba, Harry. "Explorations in Animist Materialism: Notes on Reading/Writing African Literature, Culture, and Society." Public Culture 15.2, (2003): 261285

---. "Unbearable Lightness of Being: Re-Figuring Trends in Recent Nigerian Poetry" in English in Africa 32.1 (South Africa: Rhodes, 2005): 51-72. Print.

---. Voices from the Fringe: An ANA anthology of New Nigerian Poetry. Lagos; London: Malthouse, 1988. Print.

Gates, Henry Louis,Jr. "Editor's Introduction: Writing "Race" and the Difference it Makes." Critical Inquiry 12.1, "Race," Writing, and Difference (1985): 1-20. Print.

---. The Classic Slave Narratives. New York: New American Library, 1987. Print.

---. Loose Canon: Notes on the Culture Wars. New York: Oxford University Press, 1992. Print. 
Gelb, Ignace J. A Study of Writing. Rev. ed. ed. Chicago: U. of Chicago., 1965. Print.

Gerard, Albert S. European-Language Writing in Sub-Saharan Africa. Budapest: Akadâemiai Kiadâo, 1986. Print. Comparative History of Literatures in European Languages. v. $1 \& 2$.

Gikandi, Simon. Reading the African Novel. London: Portsmouth, N.H.: J. Currey; Heinemann, 1987. Print.

---. Maps of Englishnes: Writing Identity in the Culture of Colonialism. New York: Columbia University Press, 1996. Print.

Goebel, Rolf J. "Paris, Capital of Modernity." Jstor. Monasthefte 90.4. (1998): 445-464. Web.

Goldenberg, David. The Curse of Ham : Race and Slavery in Early Judaism, Christianity, and Islam. Princeton, N.J: Princeton University Press, 2003. Print.

Graham, Lucy Valerie. "Reading the Unspeakable: Rape in J. M. Coetzee's Disgrace." Jstor. Journal of Southern African Studies 29.2 (2003): 433-444. Web.

Gran, Peter, Arif Dirlik, and Vinay Bahl. History After the Three Worlds: PostEurocentric Historiographies. Lanham, Md.: Rowman \& Littlefield, 2000. Print.

Griswold, Wendy. Bearing Witness: Readers, Writers, and the Novel in Nigeria. Princeton, N.J.: Princeton University Press, 2000. Print. Princeton Studies in Cultural Sociology.

Griscom, Amanda. Trends of Anarchy and Hierarchy: Comparing the Cultural Repercussions of Print and Digital Media. Web. Sept 16, 2010.

$<\mathrm{http}: / /$ www.cyberartsweb.org/cpace/infotech/asg/contents.html>. Ebook. 1996.

Guillory, John. Cultural Capital: The Problem of Literary Canon Formation. Chicago: University of Chicago Press, 1993. Print.

Habila, Helon. Prison Stories. Lagos: Epik Books, 2000. Print.

---. Waiting for an Angel. London, UK: Penguin, 2002. Print.

--.. Measuring Time. New York, USA. W.W. Norton, 2007. Print.

Hall, Stuart. "What is 'Black' in Black Popular Culture?" in Stuart Hall: Critical Dialogues in Cultural Studies. Morley and Chen, David Morley and Kuan-Hsing Chen. Eds. London; New York: Routledge, 1996. Print. Comedia. 
Hammond, Dorothy, and Alta Jablow. The Africa that Never was; Four Centuries of British Writing about Africa, . New York,: Twayne Publishers, [1970]. Print.

Hassan, Salah Dean Assaf. "Canons after 'Postcolonial Studies." Project Muse. Pedagogy 1.2 (2001): 297-304. Web.

Held, David. Global Transformations: Politics, Economics and Culture. Stanford, Calif: Stanford University Press, 1999. Print.

Herrnstein Smith, Barbara. "Contingencies of Value." Jstor. Critical Inquiry. 10.1. Canons (Sep., 1983): 1-35.

Hill, Allan. "The African Writers Series." Research in African Literatures 2.1 (1971): 18-20. Web.

Hochschild, Adam. King Leopold's Ghost: A Story of Greed, Terror, and Heroism in Colonial Africa. Boston: Houghton Mifflin, 1998. Print.

Hoesel-Uhlig, Stefan. "Changing Fields: The Direction of Goethe's Weltliteratur" in Debating World Literature. Christopher Prendergast. Ed. London, UK: Verso, (2004): 26-53. Print.

Holman, Valerie Carefully Concealed Connections The Ministry of Information and British Publishing, 1939-1946. Project Muse. Book History 8 (2005): 197-226. Web.

Horowitz, Evan. "London: Capital of the Nineteenth Century." Project Muse. New Literary History 41.1 (2010): 111-128. Web.

Huggan, Graham. The Postcolonial Exotic: Marketing the Margins. London; New York: Routledge, 2001. Print.

Huggins, Nathan Irvin,. Harlem Renaissance. New York,: Oxford University Press, 1971. Print.

Hyam, Ronald. Empire and Sexuality: The British Experience. Manchester; New York : New York, NY, USA: Manchester University Press ; St. Martin's Press [distributor], 1990. Print. Studies in Imperialism.

Ibironke, Olabode. Between African Writers and Heinemann Educational Publishers: The Political Economy of a Culture Industry. Diss. Michigan State U, 2008. Web.

Irele, F. Abiola. African Imagination, the: Literature in Africa and the Black Diaspora. Oxford University Press USA. Print. 
Iweala, Uzodinma. Beast of no Nation. USA: Harper 2005. Print.

Jahn, Janheinz. A History of Neo-African Literature; Writing in Two Continents. Translated from the German by Oliver Coburn and Ursula Lehrburger. London: Faber, 1968. Print.

Jameson, Frederick. "Periodizing the 60s." Jstor. Social Text. 9/10. The 60s Without Apology. (1984): 178-209. Web.

JanMohamed, Abdul R., and David Lloyd. The Nature and Context of Minority Discourse. New York: Oxford University Press, 1990. Print.

Conrad, Joseph. Heart of Darkness. New York, American Book Company:, 1934. Print.

Jules-Rosette, Bennetta. Black Paris. Urbana: Illinois UP, 1998. Print.

July, Robert. "The Primacy of Didactic Writing in English and in French" in EuropeanLanguage Writing in Sub-Saharan Africa, Vol.1. Ed. Albert S. Gerard. Budapest: Akademie Kiado. (1986): 79-97. Print.

Kesteloot, Lilyan. Intellectual Origins of the African Revolution. Washington: Black Orpheus Press, 1972. Print. Dimensions of the Black Intellectual Experience.

King, Bruce,. Introduction to Nigerian Literature. [Lagos]: University of Lagos, [1971]. Print.

Kwasi, Darko-Ampem. "A University Press Publishing Consortium for Africa: Lessons from Academic Libraries." Project Muse. Journal of Scholarly Publishing 36.2 (2005): 89-114

Larson, Charles R. "New Writers, New." Jstor. The Wilson Quarterly 4.1 (1980): 81-92. Web.

Laurence, Margaret, and Nora Foster Stovel. Long Drums \& Cannons: Nigerian Dramatists and Novelists, 1952-1966. Edmonton : University of Alberta Press, 2001. Print.

Lindfors, Bernth. Critical Perspectives on Amos Tutuola. 1st ed. ed. Washington: Three Continents Press, 1975. Print. Critical Perspectives.

---. Critical Perspectives on Nigerian Literatures. 1st ed. ed. Washington: Three Continents Press, 1976. Print. Critical Perspectives; 3.

---. Early Nigerian Literature. New York: Africana Pub. Co, 1982. Print. 
---. Long Drums Canons; Teaching and Researching African Literature. Trenton, NJ: African World Press, 1995. Print.

Livingston, Thomas W. "The Exportation of American higher Education to West Africa: Liberia College, 1850-1900." The Journal of Negro Education 45.3 (1976): 246-262. Jstor Feb 02, 2008.

Lizarribar Buxo, Camille. "Something Else Will Stand Beside it: The African Writers Series and the Development of African Literature." Harvard University, PhD Dissertation, 1998. Print.

Low, Gail Ching-Liang: "The Natural Artist: Publishing Amos Tutuola's The Palm-Wine Drinkard in Postwar Britain." Project Muse. Research in African Literatures 37.4 (2006):15-33.

Maier, Karl. This House has Fallen: Midnight in Nigeria. New York: PublicAffairs, 2000. Print.

Mama, Amina. "Is It Ethical to Study Africa? Preliminary Thoughts on Scholarship and Freedom." Project Muse. African Studies Review 50.1, (2007): 1-26. Web.

Mannoni, Octave. Prospero and Caliban : The Psychology of Colonization. 2nd ed. ed. New York; Washington: Praeger, 1964. Print.

Maran, Renâe. Batouala. Paris: Michel, 1938. Print.

Marx, Karl, and Friedrich Engels. Capital. Moscow: Progress Publishers, 1954?-1967. Print.

Mbaifu, Edmond Mfaboum. "Mongo Beti and the 'Curse' of Ham: Myth and History in Africa." Research in African Literature 33.2 (2002): 9-33). Web.

Mignolo, Walter D. "Canons A(nd)Cross-Cultural Boundaries (Or, Whose Canon are We Talking about?).” Project Muse. Poetics Today, Vol. 12, No. 1 (1991): 1-28. Web.

Miller, Christopher L.,. Theories of African: Francophone Literature and Anthropology in Africa. Chicago: University of Chicago Press, 1990. Print. Black Literature and Culture.

Memmi, Albert. The Colonizer and the Colonized. Boston: Beacon Press., 1965. Print.

Miyoshi, Masao: "Borderless World?: From Colonialism to Transnationalism and the Decline of the Nation State" in Global/Local: Cultural Production and The Transnational Imaginary. Wilson and Dissanayake. Eds. Durham/London: Duke UP, 1996. 78-108. 
Moraäna, Mabel, Enrique D. Dussel, and Carlos A. Jâauregui. Coloniality at Large: Latin America and the Postcolonial Debate. Durham: Duke University Press, 2008. Print. Latin America Otherwise.

Moses, Michael Valdez,. The Novel and the Globalization of Culture. New York: Oxford University Press, 1995. Print.

Mudimbe, V. Y. The Invention of Africa: Gnosis, Philosophy, and the Order of Knowledge. Bloomington: Indiana University Press, 1988. Print. African Systems of Thought. Print.

Nandy, Ashis. The Intimate Enemy: Loss and Recovery of Self Under Colonialism. Delhi: Oxford, 1983. Print.

--.. "Imperialism as a Theory of the Future" in Cultural Imperialism: Essays on the Political Economy of Cultural Domination. Bernd Hamm and Russell Smandych. Eds Peterborough, Ont.: Broadview Press, (2004): 52-59. Electronic.

Ndibe, Okey. Arrows of Rain. Oxford; Portsmouth, NH: Heinemann, 2000. Print. African Writers Series.

Nnolim, Charles. "Contemplating Contemporary Nigerian Fiction." Nigerian Guardian, 5 August 2005. Print.

Nnorom, Azuonye. "Of Generations and Limits." Interview. Web. 04, September 2007. Web. <http://www.sentinelpoetry.org.uk/0607/adesanmi_interview.htm>.

---. What is Illuminating about Adichie's 'The Danger of a Single Story'?" Web. 20 April 2009. <http://www.mtls.ca/issue5/writings-essay-azuonye.php>.

Nwakanma, Obi. "Metonymic Eruptions: Igbo Novelists, the Narrative of the Nation, and New Developments in the Contemporary Nigerian Novel." Research in African Literatures 39.2 (2008): 1-14. Project MUSE. Web.

Nwaubani, Tricia Adaobi. I do not Come to You by Chance. USA: Hyperion, 2009. Print.

Nwosu, Maik. Invisible Chapters. Lagos: House of Malaika \& Hybun. 2001. Print.

Ngugi wa Thiong'o. "Europhonism, Universities, and the Magic Fountain: The Future of African Literature and Scholarship."Research in African Literatures 31.1 (2000): 1-11. Web.

---. Decolonising the Mind : The Politics of Language in African Literature. London: Portsmouth, N.H: J. Currey ; Heinemann, 1986. Print. 
Obenga, Theophilus. African Philosophy: The Pharaonic Period: 2780-330 BC Trans. Ayi Kwei Armah. Popenguine Senegal: Per Ankh, 2004. Print.

Obiechina, Emmanuel N. Literature for the Masses: An Analytical Study of Popular Pamphleteering in Nigeria. Enugu, Nigeria: Nwankwo-Ifejika, 1971. Print.

--.. Onitsha Market Literature. London: Heinemann Educational, 1972. Print. African Writers Series, 109.

Odozor, Livinus Nwadiuto. Contemporary Nigerian Literature and the Idea of a Canon. Diss. U of Toronto, 2004. Web.

Ofeimun “Against a Ghetto Prize for Writers.” Nigerian Guardian, May 10, 2004).

---. "The NLNG Literature Prize Controversy."Nigerian Guardian, Nov 28, 2004.

Oguine, Ike. A Squatter's Tale. Oxford; Chicago: Heinemann, 2000. Print. African Writers Series.

Ong, Walter J. "Orality and Literacy" in The Book History Reader. Eds. David Finkelstein and Alistair McCleery. Routledge 2002. 105-117.

Onoge, Omafume F. "The Crisis of Consciousness in Modern African Literature: A Survey." Jstor. Canadian Journal of African Studies / Revue Canadienne des Études Africaines 8.2 (1974): 385-410. Web.

Osaghae, Eghosa E. Crippled Giant : Nigeria since Independence. Bloomington: Indiana University Press, 1998. Print.

Osha, Sanya. Naked Light and the Blind Eye. London: Future Fiction, 2010. Print.

---. "Writing in a Continent Under Siege." Research in African Literatures 29.1 (1998): 174-8. Print.

Oyono, Ferdinand. Houseboy. London: Heinemann, 1966. Print. African Writers Series ; 29.

Parascandola, Louis J. “'What Are We Blackmen Who Are Called French?': The Dilemma of Identity in Oyono's Un vie de boy and Sembène's La Noire de ..." Project Muse. Comparative Literature Studies 46.2 (2009): 360-378. Web. 
Parry, Benita. Postcolonial Studies: A Materialist Critique. London; New York: Routledge, 2004. Print. Postcolonial Literatures. Print.

Potkay, Adam, and Sandra Burr. Black Atlantic Writers of the Eighteenth Century: Living the New Exodus in England and the Americas. 1st ed. ed. New York: St. Martin's Press, 1995. Print.

Peterson, Richard A. "Six Constraints on the Production of Literary Works. Poetics 14. (1985): 45-67. Web.

Quayson, Ato. Postcolonizing; Theory, Practice, Or Process? Malden, Mass.: Polity Press, 2000. Print.

----. Strategic Transformations in Nigerian Writing. London, UK: James Currey, 1997. Print.

Quijano, Anibal and Ennis, Michael. "Coloniality of Power, Eurocentrism, and Latin America." Project Muse. Nepantla: Views from South, 1.3 (2000): 533-580. Web.

Raji, Wumi. "Identity and Narrativity in a Postcolonial Context:" Review. Okey Ndibe: Arrows of Rain: Ike Oguine: A Squatter's Tale. English in Africa 32.1 (2005): 143148.

Said, Edward W. Culture and Imperialism. 1st ed. ed. New York: Knopf: Distributed by Random House, 1993. Print.

---. Orientalism. New York,: Vintage Books., 1978. Print.

Sartre, Jean-Paul. What is Literature? Translated from the French by Bernard Frechtman. Gloucester, Mass: P. Smith, 19781965. Print.

Schmeling, Manfred. Weltliteratur Heute: Konzepte Und Perspektiven. Wèurzburg: Kèonigshausen \& Neumann, 1995. Print. Saarbrèucker Beitrèage Zur Vergleichenden Literatur- Und Kulturwissenschaft; Bd. 1.

Shepperson, George. "Ethiopianism and African Nationalism." Jstor. Phylon (19401956), 14.1 (1st Qtr., 1953): 9-18.

-.-. "Notes on Negro American Influences on the Emergence of African Nationalism. Jstor. The Journal of African History 1.2 (1960): 299-312. Accessed 30 June 2008. Web.

Shoneyin, Lola. The Secret Lives of Baba Segi's Wives. UK: William Morrow, 2010. Print.

Spivak, Gayatri Chakravorty. Outside in the Teaching Machine. New York: Routledge, 1993. Print. 
Soyinka, Wole. The Open Sore of a Continent : A Personal Narrative of the Nigerian Crisis. New York: Oxford University Press, 1996. Print.

Stec, Loretta. "Publishing and Canonicity: The Case of Heinemann's 'African Writers Series."” Jstor. Pacific Coast Philology 32.2. Convention Program Issue (1997): 140149

Sullivan, Johanna. "The Question of a National Literature for Nigeria." Jstor. Research in African Literatures 32.3 (2001): 71-85. Web.

Tasie, M. O. G. Christian Missionary Enterprise in The Niger Delta 1864-1918. Ibadan History Series. Ed. K.O. Dike. Leiden: E. J. Brill: 1978. Print.

Tâetreault, Mary Ann, and Charles F. Abel. Dependency Theory and the Return of High Politics. New York: Greenwood Press, 1986. Print. Contributions in Political Science, no. 140.

Thomas, Nicholas. Colonialism's Culture : Anthropology, Travel, and Government. Princeton, N.J: Princeton University Press, 1994. Print

Tomlinson, John. Cultural Imperialism: A Critical Introduction. London: Pinter Publishers, 1991. Print.

Viswanathan, Gauri. Masks of Conquest: Literary Study and British Rule in India. New York: Columbia University Press, 1989. Print. Social Foundations of Aesthetic Forms Series.

Wainaina, Binyanvanga. "How to Write about Africa." Web. 19 Oct. 2012.

$2^{\text {nd }}$ Ed. <http://www.granta.com/Archive/92/How-to-Write-about-Africa/Page-1>.

West, Cornel. "The New Cultural Politics of Difference" in Out There: Marginalization and Contemporary Cultures. Eds. Russell Ferguson et al. New York, N.Y.: Cambridge, Mass.: New Museum of Contemporary Art; MIT Press (1990): 19-36. Print. Documentary Sources in Contemporary Art; v. 4.

Zeleza, Paul Tiyambe. "African Studies and Universities since Independence: the Challenges of Epistemic and Institutional Decolonization." Project Muse. Transition 101 (2009): 110-135 